\title{
Total Synthesis of Topopyrones B and D
}

\author{
Jason Tan, Marco A. Ciufolini* \\ Department of Chemistry, University of British Columbia, 2036 Main Mall, Vancouver, BC V6T 1Z1, Canada
}

\section{Supporting Information}




\section{Table of Contents}

$\underline{\text { Subject }}$

page

Experimental Protocols $\quad 3$

Synthesis of intermediates $\mathbf{6 , 7}, \mathbf{7}, \mathbf{2 2}, \mathbf{2 4}$

preparation of 2-carbethoxymethyl-2-methyl-dioxolane 3

preparation of 2-(2-hydroxyethyl)-2-methyl-dioxolane 3

preparation of aldehyde $\mathbf{1 0} \quad 3$

preparation of benzamide $6 \quad 4$

preparation of 3-chloro-2,4-dihydroxybenzaldehyde 4

preparation of 3-chloro-2,4-dimethoxybenzaldehyde 4

preparation of 3-chloro-2,4-dimethoxybenzoic acid 4

preparation of benzamide $7 \quad 5$

preparation of 4-bromo-3,5-dimethoxybenzyl alcohol 5

preparation of TBS ether 9

preparation of compound $\mathbf{1 1} \quad 5$

preparation of compound $\mathbf{1 2} 6$

preparation of compound $\mathbf{1 3} \quad 6$

$\begin{array}{ll}\text { preparation of compound } \mathbf{1 4} & 6\end{array}$

$\begin{array}{ll}\text { preparation of aldehyde } 8 & 7\end{array}$

$\begin{array}{ll}\text { preparation of aldehyde } \mathbf{2 1} & 7\end{array}$

$\begin{array}{ll}\text { preparation of anthraquinone } \mathbf{2 3} & 7\end{array}$

Synthesis of topopyrone D

preparation of anthraquinone $\mathbf{1 7}$

deprotection of anthraquinone $\mathbf{1 7} \quad 8$

$\begin{array}{ll}\text { preparation of anthraquinone } 24 & 8\end{array}$

$\begin{array}{ll}\text { topopyrone D } 4 & 8\end{array}$

$\begin{array}{ll}\text { topopyrone D triacetate } \mathbf{2 6} & 9\end{array}$

Synthesis of topopyrone B $\quad 9$

preparation of anthraquinone $18 \quad 9$

deprotection of anthraquinone $\mathbf{1 8} \quad 9$

$\begin{array}{lr}\text { preparation of anthraquinone } \mathbf{2 4} & 10\end{array}$

$\begin{array}{ll}\text { topopyrone B trimethyl ether } 27 & 10\end{array}$

Index of hardcopy ${ }^{1} \mathrm{H}$ and ${ }^{13} \mathrm{C}$ NMR spectra $\quad 11$

$\begin{array}{lr}\text { spectra } & 12\end{array}$ 


\section{Experimental Protocols.}

Unless otherwise stated, proton and ${ }^{13} \mathrm{C}$ NMR spectra were obtained from $\mathrm{CDCl}_{3}$ solutions. Chemical shifts are reported in parts per million (ppm) on the $\delta$ scale and coupling constants, $J$, are in hertz (Hz). Multiplicities are reported as "s" (singlet), “d” (doublet), "t” (triplet), "q" (quartet), “dd” (doublet of doublets), “td” (triplet of doublets), “m” (multiplet), “c” (complex), "br" (broad). FT-IR spectra $\left(\mathrm{cm}^{-1}\right)$ were from thin films deposited on $\mathrm{NaCl}$ plates. Low- and high-resolution mass spectra $(\mathrm{m} / \mathrm{z})$ were obtained in the electrospray (ESI) mode. Melting points are uncorrected. All reagents and solvents were commercial products and used without further purification except THF (freshly distilled from $\mathrm{Na}$ /benzophenone under $\mathrm{Ar}$ ) and $\mathrm{CH}_{2} \mathrm{Cl}_{2}$ (freshly distilled from $\mathrm{CaH}_{2}$ under Ar). Commercial $n$-BuLi was titrated against $N$ benzylbenzamide in THF at $-78^{\circ} \mathrm{C}$ until persistence of a light blue color. Flash chromatography was performed on Silicycle 230 - 400 mesh silica gel. All reactions were performed under dry $\mathrm{Ar}$ in flame or over dried flasks equipped with Teflon ${ }^{\mathrm{TM}}$ stirbars. All flasks were fitted with rubber septa for the introduction of substrates, reagents, and solvents via syringe.

Synthesis of intermediates $6,7,8,22,24$.

2-carbethoxymethyl-2-methyl-dioxolane. A solution of ethyl acetoacetate (100.0 g, $0.77 \mathrm{~mol})$, ethylene glycol $(143.0 \mathrm{~g}, 2.30 \mathrm{~mol})$, and $p-\mathrm{TsOH} \cdot \mathrm{H}_{2} \mathrm{O}$ (6.5 g, $34.2 \mathrm{mmol})$ in benzene (1000 mL; CAUTION: cancer suspect agent) was refluxed for $5 \mathrm{~h}$ with continuous azeotropic $\mathrm{H}_{2} \mathrm{O}$ separation (Dean-Stark

trap). The mixture was then cooled to RT, concentrated to $500 \mathrm{~mL}$ in vacuo. washed sequentially with sat. aq. $\mathrm{NaHCO}_{3}(2 \times 100 \mathrm{~mL})$ and brine $(100 \mathrm{~mL})$, dried $\left(\mathrm{Na}_{2} \mathrm{SO}_{4}\right)$, filtered and concentrated to afford the title ketal ester (120.5 g, 90\%) as a colorless oil. This material was of excellent quality and required no further purification. ${ }^{1} \mathbf{H}$ : 4.06 (q, $2 \mathrm{H}, J=6.6$ ), 3.88 (s, $4 \mathrm{H}), 2.57$ (s, 2H), 1.41 (s, 3H), 1.17 (t, 3H, $J=6.6) .{ }^{13} \mathrm{C}: 169.2,107.4,64.5,60.2,44.0,24.2$, 13.9. IR: 1747. HRMS calcd for $\mathrm{C}_{8} \mathrm{H}_{14} \mathrm{O}_{4}[\mathrm{M}+\mathrm{Na}]^{+}=197.0790$, found 197.0791.

2-(2-hydroxyethyl)-2-methyl-dioxolane. A solution of the above ketal ester $(9.0 \mathrm{~g}, 51.7 \mathrm{mmol})$ in dry THF $(20 \mathrm{~mL})$ was added dropwise to a cold $\left(-5^{\circ} \mathrm{C}\right.$; ice-salt bath) suspension of LAH $(1.97 \mathrm{~g}, 51.7 \mathrm{mmol})$ in dry THF $(80 \mathrm{~mL})$. The reaction mixture was stirred at $0{ }^{\circ} \mathrm{C}$ for $1.5 \mathrm{~h}$ then quenched with aq. sat.

$\mathrm{Na} / \mathrm{K}$ tartrate soln. (100 mL. CAUTION: vigorous evolution of highly flammable $\mathrm{H}_{2}$ gas). The organic layer was separated and the aqueous layer was extracted with $\mathrm{Et}_{2} \mathrm{O}(2 \times 50 \mathrm{~mL})$. The combined organic layers were washed with brine $(100 \mathrm{~mL})$, dried $\left(\mathrm{Na}_{2} \mathrm{SO}_{4}\right)$ and concentrated to give pure title alcohol $(6.2 \mathrm{~g}, 91 \%)$ as a colorless oil. ${ }^{1} \mathbf{H}$ : 3.99 (s, $\left.4 \mathrm{H}\right), 3.76$ (broad s, 2H), 2.76 (broad s, $1 \mathrm{H}), 1.95$ (t, $2 \mathrm{H}, J=5.2$ ), 1.36 (s, 3H). ${ }^{13} \mathrm{C}$ : 110.3, 64.6, 58.8, 40.5, 23.9; IR: 3440. HRMS calcd for $\mathrm{C}_{6} \mathrm{H}_{12} \mathrm{O}_{3}[\mathrm{M}+\mathrm{Na}]^{+}=155.0684$, found 155.0683.

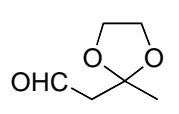

Aldehyde 10 (cf. Langer, P.; Freifeld, I. Synlett. 2001, 4, 523). Dry DMSO (2.79 $\mathrm{mL}, 39.3 \mathrm{mmol})$ was added dropwise to a cold $\left(-78{ }^{\circ} \mathrm{C}\right)$ solution of oxalyl chloride $(3.38 \mathrm{~mL}, 39.3 \mathrm{mmol})$ in dry DCM $(130 \mathrm{~mL}$; CAUTION: a vigorous exotherm ensues that produces poisonous CO gas). The mixture was stirred at $-78{ }^{\circ} \mathrm{C}$ for $15 \mathrm{~min}$, then solution of the above alcohol $(4.0 \mathrm{~g}, 30.3 \mathrm{mmol})$ in dry DCM $(20 \mathrm{~mL})$ was added dropwise. The resultant solution was stirred at $-78{ }^{\circ} \mathrm{C}$ for $30 \mathrm{~min}$, then $\mathrm{Et}_{3} \mathrm{~N}$ (16.9 mL, $121 \mathrm{mmol}$ ) was added. The mixture was stirred at $-78{ }^{\circ} \mathrm{C}$ for $5 \mathrm{~min}$ then it was allowed to warm to RT over $40 \mathrm{~min}$, with continued stirring. The reaction mixture was washed successively with aq. sat. $\mathrm{NH}_{4} \mathrm{Cl}(3 \times 50 \mathrm{~mL})$, dried $\left(\mathrm{Na}_{2} \mathrm{SO}_{4}\right)$ and concentrated to 
give pure 10 (3.6 g, 91\%) as a pale yellow oil. ${ }^{1} \mathbf{H}$ : $9.75(\mathrm{t}, 1 \mathrm{H}, J=2.8), 4.01(\mathrm{~m}, 4 \mathrm{H}), 2.71(\mathrm{~d}$, $2 \mathrm{H}, J=2.8), 1.43$ (s, 3H). ${ }^{13} \mathrm{C}: 200.3,107.6,64.8,52.2$, 24.9. IR: 1724 . HRMS calcd for $\mathrm{C}_{6} \mathrm{H}_{10} \mathrm{O}_{3}[\mathrm{M}+\mathrm{Na}]^{+}=153.0528$, found 153.0527 .

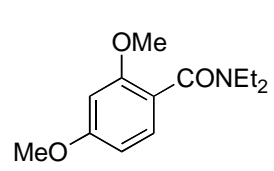

$\boldsymbol{N}, \boldsymbol{N}$-diethyl-2,4-dimethoxybenzamide 6 (cf. Kamila, S.; Mukherjee, C.; Mondal, S.; De, A. Tetrahedron. 2003, 59, 1339). Diethylamine (7.12 mL, $68.5 \mathrm{mmol})$ was carefully added to a cold $\left(0{ }^{\circ} \mathrm{C}\right)$ solution of 2,4dimethoxybenzoyl chloride $(4.58 \mathrm{~g}, 22.8 \mathrm{mmol})$ in dry toluene $(70 \mathrm{~mL})$, and the mixture was stirred at $0{ }^{\circ} \mathrm{C}$ for $1 \mathrm{~h}$ then warmed to RT and stirred

for another $5 \mathrm{~h}$. The solution was concentrated and the residue was partitioned between ethyl acetate $(50 \mathrm{~mL})$ and aq. sat. $\mathrm{NaHCO}_{3}(50 \mathrm{~mL})$. The organic layer was washed successively with $1 \mathrm{M} \mathrm{HCl}(50 \mathrm{~mL}), \mathrm{H}_{2} \mathrm{O}(50 \mathrm{~mL})$, and brine $(50 \mathrm{~mL})$, dried $\left(\mathrm{Na}_{2} \mathrm{SO}_{4}\right)$ and concentrated to give pure amide 6 (4.8 g, 89\%) as a pale yellow oil. ${ }^{1} \mathbf{H}$ : $7.05(\mathrm{~d}, 1 \mathrm{H}, J=8.4), 6.43(\mathrm{dd}, 1 \mathrm{H}, J$ $=8.4,2.0), 6.39$ (d, 1H, $J=2.0), 3.74$ (s, 3H), 3.73 (s, 3H), 3.49 (broad q, 2H), 3.09 (q, 2H, $J$ $=7.2$ ), 1.16 (t, 3H, $J=7.6), 0.97(\mathrm{t}, 3 \mathrm{H}, J=7.2) .{ }^{13} \mathrm{C}: 168.6,161.0,156.3,128.1,119.6$, 104.4, 98.4, 55.3, 55.2, 42.6, 38.7, 13.8, 12.7. IR: intense band with fine structure between 1680 and 1615. HRMS calcd for $\mathrm{C}_{13} \mathrm{H}_{18}{ }^{35} \mathrm{ClNO}_{3}[\mathrm{M}+\mathrm{Na}]^{+}=294.0873$, found 294.0870.

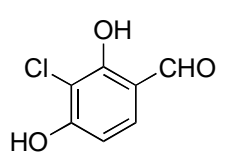

3-Chloro-2,4-dihydroxybenzaldehyde (cf. Bui, E.; Bayle, J. P.; Perez, F.; Liebert, L.; Courtieu, J. Liq. Cryst. 1990, 8, 513 ). A suspension of 2,4dihydroxybenzaldehyde (2.0 g, $14.5 \mathrm{mmol}$, Fluka) in $\mathrm{H}_{2} \mathrm{O}(10 \mathrm{~mL})$ was sequentially treated at RT with a solution of $\mathrm{KOH}(2.0 \mathrm{~g}, 35.6 \mathrm{mmol})$ in $\mathrm{H}_{2} \mathrm{O}(15 \mathrm{~mL})$, followed by commercial bleach containing 6\% NaOCl (21

$\mathrm{mL}, 16 \mathrm{mmol}$ ). The reaction mixture was stirred at RT for $3 \mathrm{~h}$ then it was acidified with $6 \mathrm{M}$ $\mathrm{HCl}(20 \mathrm{~mL})$ and extracted with EtOAc $(2 \times 50 \mathrm{~mL})$. The combined organic extracts were dried $\left(\mathrm{Na}_{2} \mathrm{SO}_{4}\right)$ and concentrated. Purification by flash chromatography (EtOAc:hexanes, 1:1) gave pure aldehyde 3-chloro-2,4-dihydroxybenzaldehyde (2.4 g, quantitative) as a white solid, m.p. $146-148{ }^{\circ} \mathrm{C}$ (no m.p. was recorded in the literature). ${ }^{1} \mathbf{H}$ (acetone- $d_{6}$ ): 9.80 (s, $1 \mathrm{H}$ ), 7.60 (d, $1 \mathrm{H}, J=8.8$ ), 6.75 (d, $1 \mathrm{H}, J=8.8) .{ }^{13} \mathrm{C}: 197.1,162.5,161.6,135.5,117.1,110.5,109.1$. IR: 1634. HRMS calcd for $\mathrm{C}_{7} \mathrm{H}_{5}{ }^{35} \mathrm{ClO}_{3}[\mathrm{M}+\mathrm{H}]^{+}=173.0005$, found 173.0007.

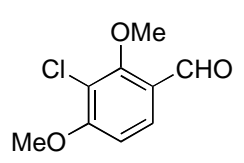

3-Chloro-2,4-dimethoxybenzaldehyde. Neat MeI (7.9mL, $127 \mathrm{mmol}$. CAUTION: toxic, volatile, cancer suspect agent) was added at RT to a solution of the above aldehyde $(2.2 \mathrm{~g}, 12.7 \mathrm{mmol})$ in acetone $(50 \mathrm{~mL})$ containing suspended $\mathrm{K}_{2} \mathrm{CO}_{3}(17.6 \mathrm{~g}, 127 \mathrm{mmol})$. The mixture was refluxed for $5 \mathrm{~h}$, then it was filtered and concentrated, and the residue was

purified by flash chromatography (EtOAc : hexanes, 1:4) to give pure 3-chloro-2,4dimethoxybenzaldehyde $(2.2 \mathrm{~g}, 85 \%)$ as a white solid, m.p, $105-107{ }^{\circ} \mathrm{C}$ (lit. $109-11{ }^{\circ} \mathrm{C}$ : Plattner, J. J.; Fung, A. K. L.; Parks, J. A.; Pariza, R. J.; Crowley, S. R.; Pernet, A. G.; Bunnell, P. R.; Dodge, P. W. J. Med. Chem. 1984, 27, 1016) ${ }^{1} \mathbf{H}: 10.19$ (s, 1H), 7.75 (d, 1H, $J=9.1$ ), 6.81 (d, $1 \mathrm{H}, J=9.1$ ), 3.96 (s, 3H), 3.95 (s, 3H). ${ }^{13} \mathrm{C}: 187.9,161.1,160.5,127.8$, 123.8, 116.6, 107.7, 62.9, 56.6. IR: 1681. HRMS calcd for $\mathrm{C}_{9} \mathrm{H}_{9}{ }^{35} \mathrm{ClO}_{3}[\mathrm{M}+\mathrm{H}]^{+}=201.0318$, found 201.0317;

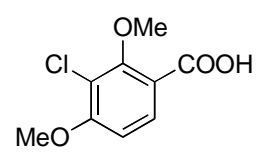

3-Chloro-2,4-dimethoxybenzoic acid. A solution of $\mathrm{NaClO}_{2}(80 \%, 1.4 \mathrm{~g}$, $12.3 \mathrm{mmol})$ in a $\mathrm{NaH}_{2} \mathrm{PO}_{4}$ buffer (pH 3.5, $\left.50 \mathrm{~mL}\right)$ was carefully added to a solution of the above aldehyde (2.06 g, $10.3 \mathrm{mmol})$ in $t$-butanol $(50 \mathrm{~mL})$ containing 2-methyl-2-butene (2.0M in THF, $6.2 \mathrm{~mL}, 12.4 \mathrm{mmol})$. The mixture was stirred at RT overnight, then it was basified with $1 \mathrm{M} \mathrm{NaOH}$ 
$(10 \mathrm{~mL})$ and the aqueous layer was washed with EtOAc $(2 \times 25 \mathrm{~mL})$. The aqueous layer was reacidified with $6 \mathrm{M} \mathrm{HCl}(5 \mathrm{~mL})$ and extracted with EtOAc $(2 \times 40 \mathrm{~mL})$. The combined extracts were dried $\left(\mathrm{Na}_{2} \mathrm{SO}_{4}\right)$ and concentrated to give pure title acid $(2.0 \mathrm{~g}, 90 \%)$ as a white solid, m.p. $168-170{ }^{\circ} \mathrm{C} .{ }^{1} \mathbf{H}$ : 8.07 (d, $1 \mathrm{H}, J=9.1$ ), 6.88 (d, $1 \mathrm{H}, J=9.1$ ), 4.08 (s, 3H), 3.99 (s, $3 \mathrm{H}) .{ }^{13} \mathrm{C}$ (acetone- $d_{6}$ ): $165.8,160.4,158.5,131.9,119.0,118.1,108.2,62.0,57.0$. IR: 1695. HRMS calcd for $\mathrm{C}_{9} \mathrm{H}_{9}{ }^{35} \mathrm{ClO}_{4}[\mathrm{M}+\mathrm{Na}]^{+}=239.0087$, found 239.0089.<smiles>CCOC(=O)c1ccc(OC)c(OC)c1OC</smiles>

$\mathbf{N}, \mathbf{N}$-diethyl-3-chloro-2,4-dimethoxybenzamide 7. Thionyl chloride (1.0 mL, 13.8 mmol; CAUTION: corrosive, toxic) was carefully added to a solution of the above acid (2.0 g, $9.2 \mathrm{mmol})$ in dry benzene $(65 \mathrm{~mL}$; CAUTION: cancer suspect agent) and the mixture was refluxed for $3 \mathrm{~h}$

(CAUTION: evolution of corrosive $\mathrm{HCl}$ gas). The mixture was then cooled to $0{ }^{\circ} \mathrm{C}$ prior to dropwise addition of a solution of diethylamine $(7.65 \mathrm{~mL}, 73.6 \mathrm{mmol})$ in dry benzene $(10 \mathrm{~mL}$ CAUTION: cancer suspect agent). The mixture was stirred overnight at RT, then it was washed with $1 \mathrm{M}$ aq. $\mathrm{NaOH}(2 \times 50 \mathrm{~mL})$, dried $\left(\mathrm{Na}_{2} \mathrm{SO}_{4}\right)$ and concentrated. The residue of crude amide was recrystallized (EtOAc:hexanes, 1:1) to afford pure 7 (1.9 g, 76\%) as tan crystals, m.p. $70-72{ }^{\circ} \mathrm{C} .{ }^{1} \mathbf{H}: 7.11$ (d, $\left.1 \mathrm{H}, J=8.7\right), 6.73$ (d, $\left.1 \mathrm{H}, J=8.7\right), 3.91$ (s, 3H), 3.87 (s, 3H), 3.74, 3.36 (br s, 2H), 3.15 (q, 2H, $J=7.3$ ), 1.24 (t, 3H, $J=7.3$ ), 1.02 (t, $3 \mathrm{H}, J=7.3$ ). ${ }^{13} \mathrm{C}$ : 167.8, 156.8, 153.4, 125.8, 125.6, 116.8, 107.7, 61.9, 56.6, 43.2, 39.2, 14.1, 12.9. IR: 1634. HRMS calcd for $\mathrm{C}_{13} \mathrm{H}_{18}{ }^{35} \mathrm{ClNO}_{3}[\mathrm{M}+\mathrm{Na}]^{+}=294.0873$, found 294.0870.<smiles>COc1cc(O)cc(OC)c1Br</smiles>

4-Bromo-3,5-dimethoxybenzyl alcohol. Commercial $\mathrm{BH}_{3} \cdot \mathrm{SMe}_{2}$ solution (36.3 mL, $0.38 \mathrm{~mol}$ ) was added dropwise to a solution of 3,5-dimethoxy4-bromobenzoic acid (50.0 g, $0.19 \mathrm{~mol})$ in dry THF (600 mL). The mixture was stirred at $40{ }^{\circ} \mathrm{C}$ overnight, then it was quenched with $1 \mathrm{M}$ aq. $\mathrm{HCl}$ (200 mL. CAUTION: evolution of highly flammable $\mathrm{H}_{2}$ gas) and the volatiles were removed in vacuo. The aqueous residue was extracted with EtOAc ( 3 x 200 $\mathrm{mL})$, and the combined extracts were dried $\left(\mathrm{Na}_{2} \mathrm{SO}_{4}\right)$ and concentrated to give pure title alcohol (47 g, quantitative) as a white solid, m.p. $100-102{ }^{\circ} \mathrm{C}$ ( lit. $100-102{ }^{\circ} \mathrm{C}$ : Inoue, I. WO 2003072536 A1 2003). ${ }^{1} \mathbf{H}$ : 6.51 (s, 2H), 4.59 (s, 2H), 3.84 (s, 6H), 2.41 (s, 1H). ${ }^{13} \mathrm{C}$ : 156.8, 141.7, 102.8, 99.3, 64.8, 56.3. IR: 3310. HRMS calcd for $\mathrm{C}_{9} \mathrm{H}_{11}{ }^{79} \mathrm{BrO}_{3}\left[\mathrm{M}+\mathrm{Na}^{+}=\right.$ 268.9789, found 268.9797.

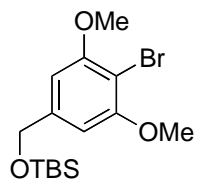

TBS ether 9. A solution of the above alcohol (47.0 g, $0.19 \mathrm{~mol})$, imidazole (25.9 g, $0.38 \mathrm{~mol})$, 4-DMAP (1.8 g, $15 \mathrm{mmol})$, and TBSCl (30.1 g, $0.20 \mathrm{~mol})$ in dry $\mathrm{CH}_{2} \mathrm{Cl}_{2}(400 \mathrm{~mL})$ was stirred at RT overnight, then it was concentrated. The residue was taken up with sat. $\mathrm{NH}_{4} \mathrm{Cl}$ aq. $(200 \mathrm{~mL})$ and extracted with EtOAc $(3 \times 150 \mathrm{~mL})$. The combined extracts were dried $\left(\mathrm{Na}_{2} \mathrm{SO}_{4}\right)$ and concentrated, and the residue was purified by flash chromatography (hexanes $\rightarrow$ EtOAc:hexanes, 1:1) to afford silyl ether 9 (68 g, quantitative) as a waxy solid, m.p. 34 - $36{ }^{\circ} \mathrm{C} .{ }^{1} \mathbf{H}$ : 6.57 (s, 2H), 4.71 (s, 2H), 3.89 (s, 6H), 0.96 (s, 9H), 0.11 (s, 6H). ${ }^{13} \mathrm{C}$ : 157.1, 142.7, 102.3, 64.8, 56.5, 26.1, 18.6, -5.1. IR: 2856, 1589, 1233. HRMS calcd for $\mathrm{C}_{15} \mathrm{H}_{25}{ }^{79} \mathrm{BrO}_{3} \mathrm{Si}[\mathrm{M}+\mathrm{Na}]^{+}=383.0654$, found 383.0655 .

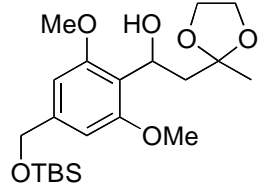

Compound 11. A pentane solution of $t$-BuLi (1.45M $10.5 \mathrm{~mL}, 15.2$ $\mathrm{mmol})$ was added dropwise to a cold $\left(-78{ }^{\circ} \mathrm{C}\right)$ solution of 9 (2.5 g, 6.9 $\mathrm{mmol})$ in dry THF (25 $\mathrm{mL})$, followed by a solution of aldehyde $\mathbf{1 0}$ (0.90 g, $6.9 \mathrm{mmol}$ ) in dry THF (5 mL). The mixture was stirred at $-78{ }^{\circ} \mathrm{C}$ for $1 \mathrm{~h}$ then it was allowed to warm to RT overnight. The reaction was quenched 
with sat. $\mathrm{NH}_{4} \mathrm{Cl}$ aq. (30 mL) and the aqueous layer was extracted with EtOAc $(2 \times 30 \mathrm{~mL})$. The combined extracts were dried $\left(\mathrm{Na}_{2} \mathrm{SO}_{4}\right)$ and concentrated. Chromatographic purification of the residue (EtOAc:hexanes, 1:1) gave $\mathbf{1 1}(1.9 \mathrm{~g}, 67 \%)$ as a pale orange oil. ${ }^{1} \mathbf{H}$ : 6.53 (s, 2H), 5.43 (ddd, $1 \mathrm{H}, J=9.6,9.6,3.9), 4.70$ (s, 2H), 3.97 (m, 4H), 3.82 (s, 6H), 3.54 (d, $1 \mathrm{H}, J$ = 9.6), 2.43 (dd, $1 \mathrm{H}, J=15.0,9.6$ ), 1.97 (dd, $1 \mathrm{H}, J=15.0,3.9$ ), 1.45 (s, 3H), 0.95 (s, 9H), 0.10 (s, 6H). ${ }^{13} \mathrm{C}: 157.7,142.4,118.8,109.9,101.9,65.1,64.7,64.3,63.8,55.8,45.2,26.3$, 24.3, 18.5, -4.8. IR: 3565. HRMS calcd for $\mathrm{C}_{21} \mathrm{H}_{36} \mathrm{O}_{6} \mathrm{Si}[\mathrm{M}+\mathrm{Na}]^{+}=435.2179$, found 435.2178 .

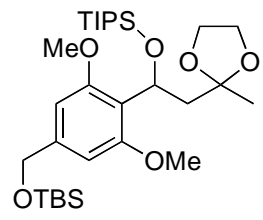

Compound 12. Neat TIPS-OTf (1.85 mL, $6.9 \mathrm{mmol})$ was carefully added to a solution of 11 (2.7 g, $6.6 \mathrm{mmol})$, imidazole (0.9 g, $13.2 \mathrm{mmol})$, and 4DMAP (64.0 mg, $0.53 \mathrm{mmol}$ ) in dry DMF (13 mL), and the mixture was stirred at RT overnight. The reaction was quenched with aq. sat. $\mathrm{NaHCO}_{3}$ $(50 \mathrm{~mL})$ and extracted with EtOAc $(2 \times 50 \mathrm{~mL})$. The combined extracts were washed with brine $(50 \mathrm{~mL})$, dried $\left(\mathrm{Na}_{2} \mathrm{SO}_{4}\right)$ and concentrated. The

residue was purified by flash chromatography (hexanes $\rightarrow$ EtOAc:hexanes, 1:4) to afford silyl ether 12 (3.5 g, 94\%) as colorless oil. ${ }^{1} \mathbf{H}: 6.50$ (br s, $\left.1 \mathrm{H}\right), 6.46$ (br s, $\left.1 \mathrm{H}\right), 5.57$ (dd, $1 \mathrm{H}, J$ $=9.2,4.4), 4.70$ (br s, 2H), 3.85-3.78 (c, 4H), 3.78 (s, 3H), 3.77 (s, 3H), 2.76 (dd, $1 \mathrm{H}, J=$ 14.4, 9.2), 2.23 (dd, $1 \mathrm{H}, J=14.4,4.4), 1.24$ (s, 3H), 1.00-0.98 (m, 12H), 0.94 (s, 9H), 0.890.85 (m, 9H), 0.08 (s, 6H). ${ }^{13} \mathrm{C}: 160.1,157.0,142.1,120.0,109.5,102.8,101.1,65.3,64.4$, 64.3, 63.1, 55.6, 55.6, 45.1, 26.0, 24.5, 18.2, 18.0, 17.9, 12.5, -5.0. IR: 2865, 1610, 1228. HRMS calcd for $\mathrm{C}_{30} \mathrm{H}_{56} \mathrm{O}_{6} \mathrm{Si}_{2}[\mathrm{M}+\mathrm{Na}]^{+}=591.3513$, found 591.3518.

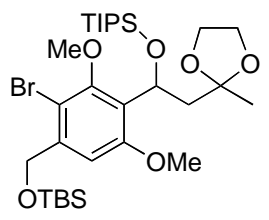

Compound 13. A solution of 12 (3.5 g, $6.2 \mathrm{mmol})$ and NBS (1.1 g, 6.2 $\mathrm{mmol})$ in $\mathrm{CH}_{3} \mathrm{CN}(20 \mathrm{~mL})$ was stirred at $\mathrm{RT}$ for $1.5 \mathrm{~h}$, then it was diluted with aq. sat. $\mathrm{NaHCO}_{3}$ aq. (30 mL) and extracted with EtOAc $(2 \times 30 \mathrm{~mL})$. The combined extracts were washed with brine $(50 \mathrm{~mL})$, dried $\left(\mathrm{Na}_{2} \mathrm{SO}_{4}\right)$ and concentrated to give pure $\mathbf{1 3}$ (4.0 g, quantitative) as a colorless oil. Proton and ${ }^{13} \mathrm{C}$ NMR spectra indicated that this material exists as a ca. $4: 1$ mixture of atropisomers. Major atropisomer: ${ }^{1} \mathbf{H}$ : 6.94 (s, $\left.1 \mathrm{H}\right), 5.57$ (dd, $1 \mathrm{H}, J=10.5,3.6$ ), 4.70 (br AB-type system, 2H, $J=15.1$ ), 3.93 (s, 3H), 3.80 (s, 3H), 3.81-3.69 (c, 4H), 3.14 (dd, $1 \mathrm{H}, J=14.2$, 10.5), 2.12 (dd, $1 \mathrm{H}, J=14.2$, 3.6), 1.18 (s, 3H), 1.11-0.84 (c, 21H), 0.97 (s, 9H), 0.13 (s, $6 \mathrm{H}) .{ }^{13} \mathrm{C}: 157.2,156.4,141.1,126.5,109.0,108.2,105.4,64.9,64.5,64.4,63.2,62.1$, 55.6, 44.7, 26.1, 24.4, 18.4, 18.2, 12.5, -5.1. IR: 2866. HRMS calcd for $\mathrm{C}_{30} \mathrm{H}_{55} \mathrm{O}_{6}{ }^{79} \mathrm{BrSi}_{2}[\mathrm{M}$ $+\mathrm{Na}]^{+}=669.2618$, found 669.2614 .

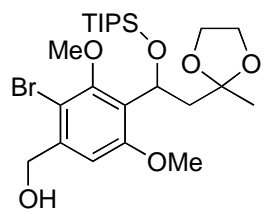

Compound 14. A solution of $13(4.0 \mathrm{~g}, 6.2 \mathrm{mmol})$ and TBAF (1.0M in THF, $5.9 \mathrm{~mL}, 6.2 \mathrm{mmol})$ in THF (20 mL) was stirred at RT for $20 \mathrm{~min}$, then it was quenched with aq. sat. $\mathrm{NaHCO}_{3}(30 \mathrm{~mL})$ and extracted with EtOAc ( $2 \times 30 \mathrm{~mL})$. The combined extracts were washed with brine (50 $\mathrm{mL}$ ), dried $\left(\mathrm{Na}_{2} \mathrm{SO}_{4}\right)$ and concentrated to give 14 (3.2 g, quantitative) as a colorless oil. Proton and ${ }^{13} \mathrm{C}$ NMR spectra indicated that this material

exists as a ca. 4:1 mixture of atropisomers. Major atropisomer: ${ }^{1} \mathbf{H}: 6.84$ (s, 1H), 5.58 (dd, $1 \mathrm{H}$, $J=10.5$, 3.5), 4.71 (br AB-type system, 2H, $J=14.0$ ), 3.93 (s, 3H), 3.82 (s, 3H), 3.78-3.68 (c, 4H), 3.13 (dd, 1H, $J=14.0,10.5$ ), 2.26 (br, 1H, OH), 2.13 (dd, $1 \mathrm{H}, J=14.0,3.5$ ), 1.40-0.80 (m, 21H), 1.17 (s, 3H). ${ }^{13} \mathrm{C}: 157.4,156.4,140.9,127.0,109.4,108.9,106.0,64.3,64.2$, 63.0, 62.0, 55.7, 53.7, 44.5, 28.5, 24.2, 20.9, 18.2, 18.1, 12.4. IR: 3430. HRMS calcd for $\mathrm{C}_{24} \mathrm{H}_{41}{ }^{79} \mathrm{BrO}_{6} \mathrm{Si}[\mathrm{M}+\mathrm{Na}]^{+}=555.1753$, found 555.1755. 
<smiles>COc1cc(C=O)c(Br)c(OCC(O)CC2(C)OCCO2)c1OC</smiles>

Aldehyde 8. Dry DMSO (0.35 mL, $4.8 \mathrm{mmol})$ was cautiously added to a cold $\left(-78{ }^{\circ} \mathrm{C}\right)$ solution of oxalyl chloride $(0.42 \mathrm{~mL}, 4.8 \mathrm{mmol})$ in dry DCM (15 mL. CAUTION: a vigorous exotherm ensues that produces poisonous $\mathrm{CO}$ gas). The mixture was stirred at $-78{ }^{\circ} \mathrm{C}$ for $15 \mathrm{~min}$, then a solution of 14 ( $2.0 \mathrm{~g}, 3.7 \mathrm{mmol})$ in dry DCM $(5 \mathrm{~mL})$ was added and the reaction was stirred at $-78{ }^{\circ} \mathrm{C}$ for $1 \mathrm{~h}$. Triethylamine $(2.1 \mathrm{~mL}, 14.8 \mathrm{mmol})$ was injected and the mixture was stirred at $-78{ }^{\circ} \mathrm{C}$ for $5 \mathrm{~min}$, then it was allowed to warm to RT with continued stirring. The reaction mixture was washed successively with aq. sat. $\mathrm{NH}_{4} \mathrm{Cl}$ aq. $(3 \mathrm{x}$ $50 \mathrm{~mL}$ ), dried $\left(\mathrm{Na}_{2} \mathrm{SO}_{4}\right)$ and concentrated. Chromatography of the residue (EtOAc:hexanes, 1:2) gave pure aldehyde 8 (1.6 g, 81\%) as a colorless semisolid. Proton and ${ }^{13} \mathrm{C}$ NMR spectra indicated that this material exists as a ca. $6: 1$ mixture of atropisomers. Major atropisomer: ${ }^{1} \mathbf{H}$ : 10.36 (s, $\left.1 \mathrm{H}\right), 7.21$ (s, $\left.1 \mathrm{H}\right), 5.61$ (dd, $\left.1 \mathrm{H}, J=10.5,3.2\right), 3.99$ (s, 3H), 3.90-3.60 (cm, 4H), 3.85 (s, 3H), 3.17 (dd, $1 \mathrm{H}, J=14.2,10.5$ ), 2.17 (dd, $1 \mathrm{H}, J=14.2,3.2$ ), 1.20 (s, 3H), 1.150.84 (cm, 21H). ${ }^{13} \mathrm{C}: 191.9,158.2,156.6,135.4,133.6,116.3,108.7,106.3,64.4,64.3,63.1$, 62.5, 56.0, 44.5, 24.3, 18.2, 18.1, 12.4. IR: 1694. HRMS calcd for $\mathrm{C}_{24} \mathrm{H}_{39}{ }^{79} \mathrm{BrO}_{6} \mathrm{Si}[\mathrm{M}+\mathrm{Na}]^{+}$ $=553.1597$, found 553.1596.

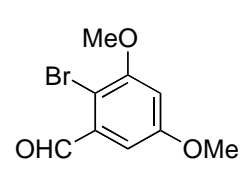

Aldehyde 21 (cf. Broering, T. J.; Morrow, Gary W. Synth. Commun. 1999, 29, 1135). A solution of bromine (3.9 mL, $12.2 \mathrm{~g}, 76 \mathrm{mmol}$. CAUTION: highly corrosive) in acetic acid $(50 \mathrm{~mL})$ was cautiously added over $1 \mathrm{~h}$ to a solution of 3,5-dimethoxybenzaldehyde (12.6 g, $76 \mathrm{mmol}$ ) in acetic acid (350 $\mathrm{mL}$ ) at RT. The mixture was stirred overnight, then it was diluted with water $(500 \mathrm{~mL})$, whereupon the product precipitated. Filtration afforded $16.4 \mathrm{~g}$ (89\%) of 21, as a white solid, m.p. $102-104{ }^{\circ} \mathrm{C}$ (lit. $105-106{ }^{\circ} \mathrm{C}$ ), which required no further purification. ${ }^{1} \mathbf{H}$ : 10.42 (s, $\left.1 \mathrm{H}\right), 7.04$ (d, $1 \mathrm{H}, J=2.7$ ), 6.71 (d, $\left.1 \mathrm{H}, J=2.7\right), 3.91$ (s, 3H), 3.85 (s, 3H).

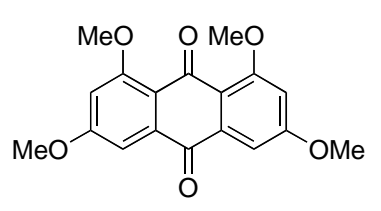

Anthraquinone 23. A solution of benzamide 6 (10.3 g, $43 \mathrm{mmol})$ in dry THF $(50 \mathrm{~mL})$ was added to a cold $\left(-78^{\circ} \mathrm{C}\right)$ solution of $\mathrm{s}$ BuLi (33 mL, 1.05 eq., $45 \mathrm{mmol})$ and TMEDA (8.5 mL, $56 \mathrm{mmol})$ in dry THF (75 mL), followed, after $1 \mathrm{~h}$, by a solution of 21 (11.2 $\mathrm{g}, 46 \mathrm{mmol})$ in dry THF (50 mL). The mixture was stirred for 45

min, then $t$-BuLi ( $58 \mathrm{~mL}$ of $1.7 \mathrm{M}$ pentane solution, $96 \mathrm{mmol}$ ). The reaction was stirred at -78 ${ }^{\circ} \mathrm{C}$ for 20 min and allowed to warm to RT overnight. The mixture was quenched with $\mathrm{H}_{2} \mathrm{O}$ $(10 \mathrm{~mL})$ and stirred for $1 \mathrm{~h}$ while bubbling air through the solution, then it was concentrated, taken up with aq. sat. $\mathrm{NaHCO}_{3}(250 \mathrm{~mL})$ and extracted with $\mathrm{CH}_{2} \mathrm{Cl}_{2}(3 \times 200 \mathrm{~mL})$. The combined extracts were dried $\left(\mathrm{Na}_{2} \mathrm{SO}_{4}\right)$ and concentrated. The yellow residue was recrystallized from EtOAc to give $5.4 \mathrm{~g}$ (40\%) of pure 23 as yellow solid, m.p. $216-218{ }^{\circ} \mathrm{C}$ (lit. 217-218 ${ }^{\circ} \mathrm{C}$ : Castonguay, A. Synth. Commun. 1975, 5, 377). ${ }^{1} \mathbf{H}$ : 7.31 (d, 2H, $J=2.4$ ), 6.76 (d, 2H, $J=2.4$ ), 3.96 (s, 6H), 3.95 (s, 6H).

Synthesis of topopyrone D.

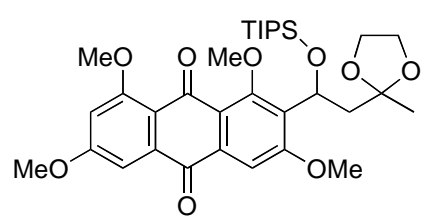

Anthraquinone 17. A solution of benzamide $6(200 \mathrm{mg}, 0.86$ mmol) in dry THF $(2 \mathrm{~mL})$ was added to a cold $\left(-78^{\circ} \mathrm{C}\right)$ solution of $s$-BuLi $(0.68 \mathrm{~mL}, 0.90 \mathrm{mmol})$ and TMEDA $(0.14 \mathrm{~mL}, 0.95$ mmol) in dry THF (4 mL), followed, after 3 h, by a solution of 8 (460 mg, $0.86 \mathrm{mmol}$ ) in dry THF $(2 \mathrm{~mL})$. The mixture was stirred for $1 \mathrm{~h}$, then $t$-BuLi $(1.32 \mathrm{~mL}$ of $1.45 \mathrm{M}$ pentane solution $1.9 \mathrm{mmol}$ ) was added. The reaction was stirred at $-78{ }^{\circ} \mathrm{C}$ for $2 \mathrm{~h}$ 
and allowed to warm to RT overnight. The mixture was quenched with $\mathrm{H}_{2} \mathrm{O}(1 \mathrm{~mL})$ and stirred for $1 \mathrm{~h}$ while bubbling air through the solution, then it was diluted with aq. sat. $\mathrm{NaHCO}_{3}(20 \mathrm{~mL})$ and extracted with EtOAc $(2 \mathrm{x} 30 \mathrm{~mL})$. The combined extracts were washed with brine $(50 \mathrm{~mL})$, dried $\left(\mathrm{Na}_{2} \mathrm{SO}_{4}\right)$ and concentrated. The yellow residue was purification by flash chromatography (EtOAc:hexanes, 1:1) to give $\mathbf{1 7}$ (80 $\mathrm{mg}, 17 \%$ ) as a bright yellow solid. Proton and ${ }^{13} \mathrm{C}$ NMR spectra indicated that this material exists as a ca. 2 : 1 mixture of atropisomers. Major atropisomer: ${ }^{1} \mathbf{H}$ : $7.48(\mathrm{~s}, 1 \mathrm{H}), 7.33(\mathrm{~d}, 1 \mathrm{H}, J=2.7), 6.78$ (d, 1H, $J=2.7$ ), 5.63 (dd, 1H, $J=10.5,3.2$ ), 4.01 (s, 3H), 3.96 (br s, 6H), 3.95 (s, 3H), 3.903.70 (cm, 4H), 3.27 (dd, $1 \mathrm{H}, J=14.2,10.5$ ), 2.15 (dd, $1 \mathrm{H}, J=14.2,3.2$ ), 1.23 (s, 3H), 1.050.85 (m, $21 \mathrm{H}) .{ }^{13} \mathrm{C}: 184.1,181,2,163.8,162.7,162.0,160.2,136.6,134.8,134.5,122.5$, 118.5, 108.8, 105.5, 104.1, 102.3, 64.5, 64.4, 63.7, 63.1, 56.8, 56.1, 44.4, 24.3, 18.3, 18.2, 12.5. IR: 1670 . HRMS calcd for $\mathrm{C}_{33} \mathrm{H}_{46} \mathrm{O} 9 \mathrm{Si}[\mathrm{M}+\mathrm{Na}]^{+}=637.2809$, found 637.2807.

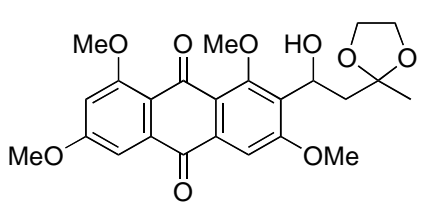

Deprotection of anthraquinone 17. A solution of 17 (45 mg, $0.073 \mathrm{mmol})$ and TBAF (1.0M in THF, $0.15 \mathrm{~mL}, 0.15 \mathrm{mmol})$ in THF $(0.5 \mathrm{~mL})$ was stirred at RT overnight, then it was diluted with aq. sat. $\mathrm{NaHCO}_{3}(30 \mathrm{~mL})$ and extracted with EtOAc $(2 \mathrm{x}$ $20 \mathrm{~mL}$ ). The combined extracts were washed with brine (50

$\mathrm{mL}$ ), dried $\left(\mathrm{Na}_{2} \mathrm{SO}_{4}\right)$ and concentrated. Chromatographic purification of the residue (EtOAc ; hexanes, 1:1) gave the free alcohol (30 $\mathrm{mg}$, quantitative) as a yellow solid. Unlike the case of 17, proton and ${ }^{13} \mathrm{C}$ NMR spectra of the present compound indicated the existence of a single species in solution. ${ }^{1} \mathbf{H}$ : 7.54 (s, $\left.1 \mathrm{H}\right), 7.33(\mathrm{~d}, 1 \mathrm{H}, J=2.8), 6.78$ (d, $\left.1 \mathrm{H}, J=2.0\right), 5.53$ (ddd, $1 \mathrm{H}, J=8.4$, 8.4, 3.2), 4.02-3.96 (m, 4H), 4.02 (s, 3H), 3.99 (s, 1H), 3.97 (s, 3H), 3.96 (s, 3H), 3.47 (d, 1H, $J=10.0$ ), 2.55 (dd, 1H, $J=14.4,9.2$ ), 2.02 (dd, 1H, $J=14.4,3.0$ ), 1.46 (s, 3H). ${ }^{13} \mathrm{C}: 183.8,181.1,164.1,162.1,161.5,159.6,136.5,134.9,133.3,122.4,118.3,109.9,105.6$, 105.0, 102.5, 64.9, 64.6, 64.3, 63.5, 44.9, 24.5. IR: 3500, 1669. HRMS calcd for $\mathrm{C}_{24} \mathrm{H}_{26} \mathrm{O}_{9}$ $[\mathrm{M}+\mathrm{Na}]^{+}=481.1475$, found 481.1478 .

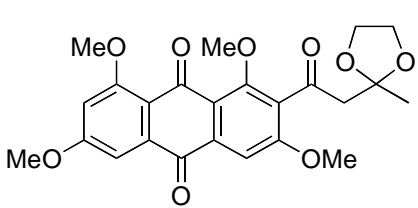

Anthraquinone 24. A mixture of the above alcohol $(7.0 \mathrm{mg}$, $0.015 \mathrm{mmol})$ and IBX (13 mg, $0.045 \mathrm{mmol})$ in $\mathrm{CH}_{3} \mathrm{CN}(1 \mathrm{~mL})$ was refluxed for $45 \mathrm{~min}$, then it was cooled to RT, filtered and concentrated. Purification of the residue by preparative TLC (EtOAc) provided $24(6.0 \mathrm{mg}, 88 \%)$ as a yellow solid. Proton and ${ }^{13} \mathrm{C}$ NMR spectra of $\mathbf{2 4}$ indicated the existence of a single

species in solution. ${ }^{1} \mathbf{H}(7.55(\mathrm{~s}, 1 \mathrm{H}), 7.35$ (d, $1 \mathrm{H}, J=2.8), 6.80(\mathrm{~d}, 1 \mathrm{H}, J=2.8), 3.98(\mathrm{~s}, 3 \mathrm{H})$, 3.97 (s, 3H), 3.97 (s, 3H), 3.96-3.91 (m, 4H), 3.94 (s, 3H), 3.18 (s, 2H), $1.54(\mathrm{~s}, 3 \mathrm{H}) .{ }^{13} \mathrm{C}$ : 199.8, 183.5, 180.4, 164.3, 162.3, 159.5, 158.8, 136.5, 136.3, 132.3, 122.3, 117.9, 107.9, 105.7, 105.2, 102.8, 64.8, 64.2, 56.8, 56.6, 56.2, 52.8, 24.6. IR: 1718, 1670. HRMS calcd for $\mathrm{C}_{24} \mathrm{H}_{24} \mathrm{O}_{9}[\mathrm{M}+\mathrm{Na}]^{+}=479.1318$, found 479.1320 .

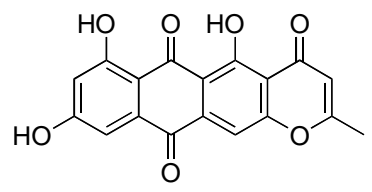

Topopyrone D, 4. A solution of $24(6.0 \mathrm{mg}, 0.013 \mathrm{mmol})$ in AcOH $(1.5 \mathrm{~mL})$ and aq. $48 \% \mathrm{HBr}(1.0 \mathrm{~mL})$ was refluxed overnight. The mixture was diluted with $\mathrm{H}_{2} \mathrm{O}(10 \mathrm{~mL})$ and extracted with EtOAc $(2 \times 40 \mathrm{~mL})$. The combined extracts were washed with brine $(50 \mathrm{~mL})$, dried $\left(\mathrm{Na}_{2} \mathrm{SO}_{4}\right)$ and concentrated to give fully synthetic topopyrone $\mathrm{D}$ (5 mg, quantitative) as an orange solid. ${ }^{1} \mathbf{H}$ (DMSO- $d_{6}$ ): 7.55 (s, 1H), 7.07 (d, 1H, J = 2.3), 6.60 (d, 1H, J = 2.3), $6.52(\mathrm{~s}, 1 \mathrm{H}), 2.47(\mathrm{~s}, 3 \mathrm{H}) .{ }^{13} \mathbf{C}$ (DMSO- $d_{6}$ ): 185.4, 182.1, 180.8, 169.9, 164.6, 164.45, 164.41, 164.0, 159.1, 138.1, 134.0, 113.5, 110.4, 110.0, 108.7, 107.6, 106.6, 20.0. 


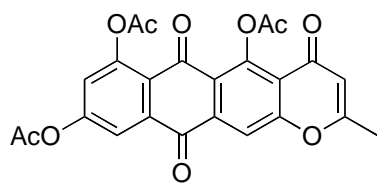

Topopyrone D triacetate 26. Synthetic 4 was acetylated as described in the literature (ref. 7 in the paper) to afford the corresponding triacetate, which was purified by preparative TLC (EtOAc). This material produced ${ }^{1} \mathrm{H}$ and ${ }^{13} \mathrm{C}$ NMR spectra in complete accord with the literature (values in brackets, ref. 7 in

the paper). ${ }^{1} \mathbf{H}$ : 8.19 [8.19] (s, $\left.1 \mathrm{H}\right), 7.97$ [7.97] (d, $1 \mathrm{H}, J=2.1$ ), 7.28 [7.28] (d, 1H, $J=2.1$ ), 6.13 [6.13] (s, 1H), 2.52 [2.52] (s, 3H), 2.45 [2.45] (s, 3H), 2. 40 [2.40] (s, 3H), 2.36 [2.36] (s, 3H). ${ }^{13} \mathrm{C}$ : 180.4 [180.2], 178.5 [178.4], 175.9 [175.7], 169.3 (2 overlapping resonances) [169.0], 168.2 [169.0], 165.9 [165.6], 159.7 [159.4], 154.9 (2 overlapping resonances) [154.7], 151.8 [151.6], 136.5 [136.3], 135.5 [135.3], 124.3 [124.1], 124.2 [124.1], 122.4 [122.3], 121.4 [121.2], 118.7 [118.4], 115.6 [115.3], 113.1 [112.8], 21.34 [21.1], 21.27 [21.0], 21.2 [20.9], 20.4 [20.1]. HRMS calcd for $\mathrm{C}_{24} \mathrm{H}_{16} \mathrm{O}_{10}[\mathrm{M}+\mathrm{Na}]^{+}=487.0641$, found 487.0645.

Synthesis of topopyrone B.

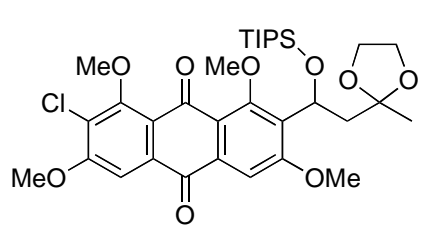

Anthraquinone 18. A solution of $7(0.20 \mathrm{~g}, 0.74 \mathrm{mmol})$ in dry THF $(1 \mathrm{~mL})$ was added to a cold $\left(-78{ }^{\circ} \mathrm{C}\right)$ solution of $t$-BuLi (1.5M pentane solution, $0.49 \mathrm{~mL}, 0.74 \mathrm{mmol}$ ) and TMEDA $(0.11 \mathrm{~mL}, 0.78 \mathrm{mmol})$ in dry THF (3 mL). After $3 \mathrm{~h}$, a solution of 8 (0.39 g, $0.74 \mathrm{mmol})$ in dry THF $(1 \mathrm{~mL})$ was added, and after stirring for $1 \mathrm{~h}, t$-BuLi (1.5M pentane solution, $0.97 \mathrm{~mL}$,

$1.48 \mathrm{mmol}$ ) was injected. The solution was stirred at $-78{ }^{\circ} \mathrm{C}$, then it was allowed to warm to RT overnight, and finally it was quenched with $\mathrm{H}_{2} \mathrm{O}(1 \mathrm{~mL})$ and stirred under a stream of air for $2 \mathrm{~h}$. The mixture was diluted with aq. sat. $\mathrm{NaHCO}_{3}(30 \mathrm{~mL})$ and extracted with EtOAc (2 x $30 \mathrm{~mL})$. The combined extracts were washed with brine $(50 \mathrm{~mL})$, dried $\left(\mathrm{Na}_{2} \mathrm{SO}_{4}\right)$ and concentrated. Chromatographic purification of the residue (EtOAc:hexanes, 1:4) gave 18 (97 $\mathrm{mg}, 20 \%$ ) as an orange oil. Proton and ${ }^{13} \mathrm{C}$ NMR spectra indicated that this material exists as a ca. 2:1 mixture of atropisomers. Major atropisomer: ${ }^{1} \mathbf{H}: 7.57$ (s, $\left.1 \mathrm{H}\right), 7.50$ (s, 1H), 5.63 (dd, 0.5H, $J=10.5$, 3.1), 4.06 (s, 3H), 4.04 (s, 3H), 3.98 (s, 3H), 3.96 (s, 3H), 3.90-3.70 (m, 4H), 3.25 (dd, $1 \mathrm{H}, J=14.0,10.5 \mathrm{~Hz}$ ), 2.19 (dd, $1 \mathrm{H}, J=14.4,3.1$ ), 1.23 (s, 3H), 1.10-0.81 (c, 21H). ${ }^{13} \mathrm{C}$ : 183.0, 180.5, 162.8, 160.6, 159.3, 134.8, 134.7, 133.4, 125.7, 123.3, 122.0, 108.9, 105.1, 104.3, 64.5, 64.4, 63.4, 63.0, 62.2, 57.1, 56.2, 44.7, 24.3, 18.3, 18.2, 12.5. Minor atropisomer: ${ }^{1} \mathbf{H}$ : 7.57 (s, 1H), 7.51 (s, 3H), 5.76 (dd, 0.5H, J = 7.4, 5.2), 4.06 (s, 3H), 4.04 (s, 3H), 3.98 (s, $3 \mathrm{H}), 3.92$ (s, 3H), 2.58 (dd, $1 \mathrm{H}, J=14.4,7.4$ ), 2.41 (dd, $1 \mathrm{H}, J=14.4,5.2$ ), 1.32 (s, 3H), 1.100.81 (c, $21 \mathrm{H}) .{ }^{13} \mathrm{C}: 182.96,180.7,163.4,159.2,157.9,157.8,134.8,134.6,134.3,125.6$, 123.4, 120.2, 109.1, 105.2, 64.5, 64.3, 63.9, 62.8, 62.2, 56.1, 56.0, 45.2, 24.6, 18.2, 18.1, 12.6. IR: 1672 . HRMS calcd for $\mathrm{C}_{33} \mathrm{H}_{45}{ }^{35} \mathrm{ClO}_{9} \mathrm{Si}[\mathrm{M}+\mathrm{Na}]^{+}=671.2419$, found 671.2422.

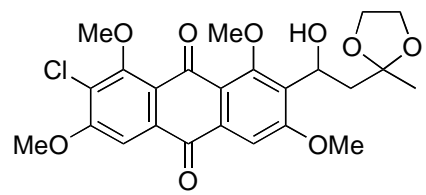

Deprotection of 18. A solution of $18(84 \mathrm{mg}, 0.13 \mathrm{mmol})$ and TBAF (1.0M in THF, $0.26 \mathrm{~mL}, 0.26 \mathrm{mmol})$ in THF (1 mL) was stirred at RT overnight, then it was diluted with aq. sat. $\mathrm{NaHCO}_{3}$ $(30 \mathrm{~mL})$ and extracted with EtOAc $(2 \times 30 \mathrm{~mL})$. The combined extracts were washed with brine $(50 \mathrm{~mL})$, dried $\left(\mathrm{Na}_{2} \mathrm{SO}_{4}\right)$ and concentrated. Chromatographic purification of the residue (EtOAc : hexanes, 1:1) gave the free alcohol (58 mg, 91\%) as a yellow solid. Unlike the case of 18, proton and ${ }^{13} \mathrm{C}$ NMR spectra of the present compound indicated the existence of a single species in solution. ${ }^{\mathbf{1}} \mathbf{H}$ : 7.58 (s, 1H), 7.55 (s, 1H), 5.55 (td, 1H, $J=9.2$, $3.1 \mathrm{~Hz}$ ), 4.07 (s, 3H), 4.04 (s, 3H), 4.00 (s, $3 \mathrm{H}$ ), 4.02-3.98 (m, 4H), 3.97 (s, 3H), 3.48 (c, 1H), 2.56 (dd, $1 \mathrm{H}, J=14.8,9.2$ ), 2.00 (dd, 1H, $J=14.8,3.5), 1.46$ (s, 3H). ${ }^{13} \mathrm{C}: 182.7,180.4,161.8,160.1,159.4,158.0,134.9$ (2 overlapping resonances), 133.3, 125.9, 123.0, 121.7, 109.9,* 105.2,* 105.1, 64.9, 64.6, 64.1, 
63.4, 62.2, 57.1, 56.6, 44.8, 24.5. IR: 3520, 1671. HRMS calcd for $\mathrm{C}_{24} \mathrm{H}_{25}{ }^{35} \mathrm{ClO}_{9}[\mathrm{M}+\mathrm{Na}]^{+}$ $=515.1085$, found 515.1087 .<smiles>COc1cc2c(c(OC)c1Cl)C(OC)c1c(cc(OC)c(CC(=O)C3(C)OCCO3)c1OC)C2=O</smiles>

Anthraquinone 25. A solution of the above alcohol (100 mg, $0.20 \mathrm{mmol})$ IBX (114 mg, $0.40 \mathrm{mmol})$ in EtOAc (2 mL) was refluxed for $3 \mathrm{~h}$, then it was cooled to $\mathrm{RT}$, diluted with more EtOAc (30 mL) and washed with $1 \mathrm{M} \mathrm{NaOH}(2 \times 50 \mathrm{~mL})$. The organic layer was dried $\left(\mathrm{Na}_{2} \mathrm{SO}_{4}\right)$ and concentrated. Purification of the residue by preparative TLC afforded 25 (90 mg, 90\%) as a yellow solid. ${ }^{1} \mathbf{H}: 7.59$ (s, 1H), 7.55 (s, 1H), 4.08 (s, 3H), 4.02 (s, 3H), 3.98 (s, 3H), 3.94 (c, 4H), 3.91 (s, 3H), 3.18 (s, 2H), 1.54 (s, 3H). ${ }^{13} \mathrm{C}: 199.6,182.5,179.8,160.0,159.6,159.0,158.2,136.2,133.2,132.9$, 126.2, 122.6, 121.6, 107.9, 105.4 (two overlapping resonances), 64.8, 64.0, 62.1, 57.2, 56.7, 52.9, 29.9. IR: 1718, 1672. HRMS calcd for $\mathrm{C}_{24} \mathrm{H}_{23}{ }^{35} \mathrm{ClO}_{9}[\mathrm{M}+\mathrm{H}]^{+}=491.1109$, found 491.1106.

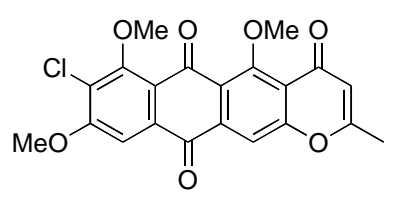

Topopyrone B trimethyl ether 27. A solution of ketone 25 (17 $\mathrm{mg}, 0.035 \mathrm{mmol})$ in conc. $\mathrm{HBr}(48 \%, 1 \mathrm{~mL})$ and acetic acid $(1.5$ $\mathrm{mL}$ ) was refluxed overnight., then it was concentrated to give crude topopyrone B (13 mg, quantitative), which without further purification was suspended in dry $\mathrm{CH}_{2} \mathrm{Cl}_{2}(0.8 \mathrm{~mL})$ and treated with solid Meerwein's salt (30 mg, $0.2 \mathrm{mmol}$ ) while stirring at

RT for $2 \mathrm{~h}$. The mixture was partitioned between EtOAc $(10 \mathrm{~mL})$ and sat. $\mathrm{NaHCO}_{3}$ aq. (10 $\mathrm{mL})$. The organic layer was dried $\left(\mathrm{Na}_{2} \mathrm{SO}_{4}\right)$ and concentrated. Purification of the residue by preparative TLC (4\% MeOH in DCM containing 0.5\% triethylamine) gave pure 27 (3.0 mg, $30 \%$ ) as a yellow solid. This material produced ${ }^{1} \mathrm{H}$ and ${ }^{13} \mathrm{C}$ NMR spectra in complete accord with the literature (values in brackets, ref. 7 in the paper). ${ }^{1} \mathbf{H}$ : 8.00 [8.00] (s, 1H), 7.59 [7.59] (s, 1H), 6.16 [6.16] (s, 1H), 4.13 [4.13] (s, 3H), 4.08 [4.08] (s, 3H), 4.04 [4.05] (s, 3H), 2.38 [2.38] (s, 3H). ${ }^{13} \mathrm{C}: 181.9$ [181.7], 179.7 [179.5], 176.4 [176.2], 165.0 [164.8], 162.5 [162.3], 160.2 [160.0], 159.7 [159.5], 158.2 [158.0], 136.9 [136.7], 133.2 [133.0], 126.3 [126.1], 124.8 [124.6], 123.7 [123.5], 122.9 [122.7], 113.2 [113.0], 112.9 [112.6], 105.1 [104.9], 64.1 [63.9], 62.3 [62.1], 57.2 [57.0], 20.2 [20.0]. IR: 1734, 1673. HRMS calcd for $\mathrm{C}_{21} \mathrm{H}_{15}{ }^{35} \mathrm{ClO}_{7}$ $[\mathrm{M}+\mathrm{H}]^{+}=415.0585$, found 415.0587 . 


\section{Index of ${ }^{1} \mathrm{H}$ and ${ }^{13} \mathrm{C}$ Spectra}

$\underline{\text { Subject }}$

page

Spectra of various Intermediates

Spectra of 2-carbethoxymethyl-2-methyl-dioxolane 12

Spectra of 2-(2-hydroxyethyl)-2-methyl-dioxolane 14

$\begin{array}{ll}\text { Spectra of aldehyde } \mathbf{1 0} & 16\end{array}$

Spectra of benzamide $6 \quad 18$

Spectra of 3-chloro-2,4-dihydroxybenzaldehyde 20

Spectra of 3-chloro-2,4-dimethoxybenzaldehyde 22

Spectra of 3-chloro-2,4-dimethoxybenzoic acid 24

$\begin{array}{ll}\text { Spectra of benzamide } 7 & 26\end{array}$

Spectra of 4-bromo-3,5-dimethoxybenzyl alcohol 28

Spectra of TBS ether $\mathbf{9} \quad 30$

Spectra of compound $\mathbf{1 1} \quad 32$

Spectra of compound $12 \quad 34$

Spectra of compound $\mathbf{1 3} \quad 36$

Spectra of compound $\mathbf{1 4} \quad 38$

Spectra of aldehyde $8 \quad 40$

Synthesis of topopyrone D $\quad 42$

Spectra of anthraquinone $17 \quad 42$

Spectra of deprotected anthraquinone $17 \quad 44$

Spectra of anthraquinone $24 \quad 46$

Spectra of topopyrone D $4 \quad 48$

Spectra of topopyrone D triacetate 26

Synthesis of topopyrone B $\quad 54$

$\begin{array}{ll}\text { Spectra of anthraquinone } 18 & 54\end{array}$

Spectra of deprotected anthraquinone $\mathbf{1 8} 56$

Spectra of anthraquinone $\mathbf{2 5}$

$\begin{array}{ll}\text { Spectra of topopyrone B trimethyl ether } \mathbf{2 6} & 60\end{array}$ 
Ciufolini, M.A., et al.

Synthesis of Topopyrones B and D

S 12

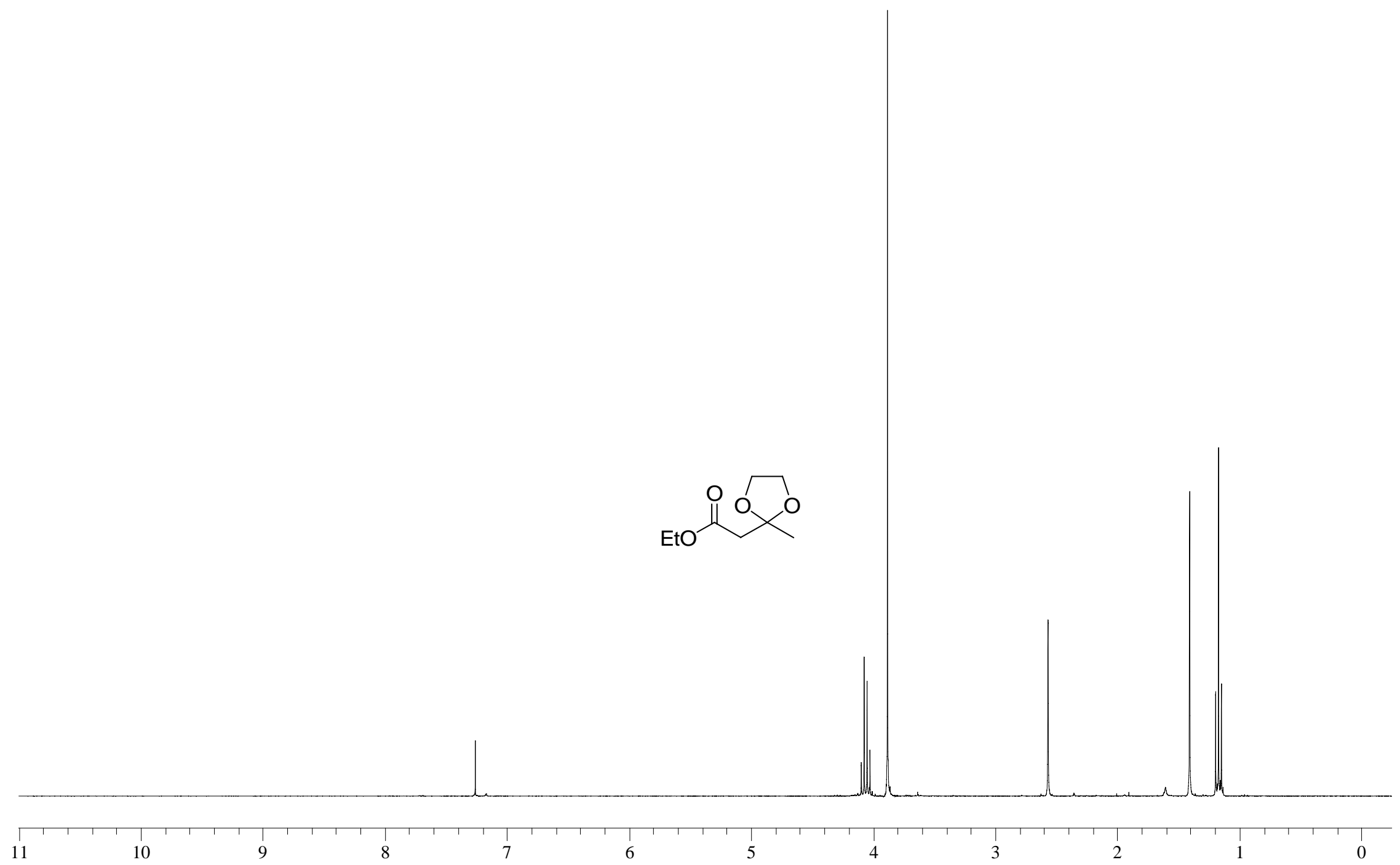

10

9 


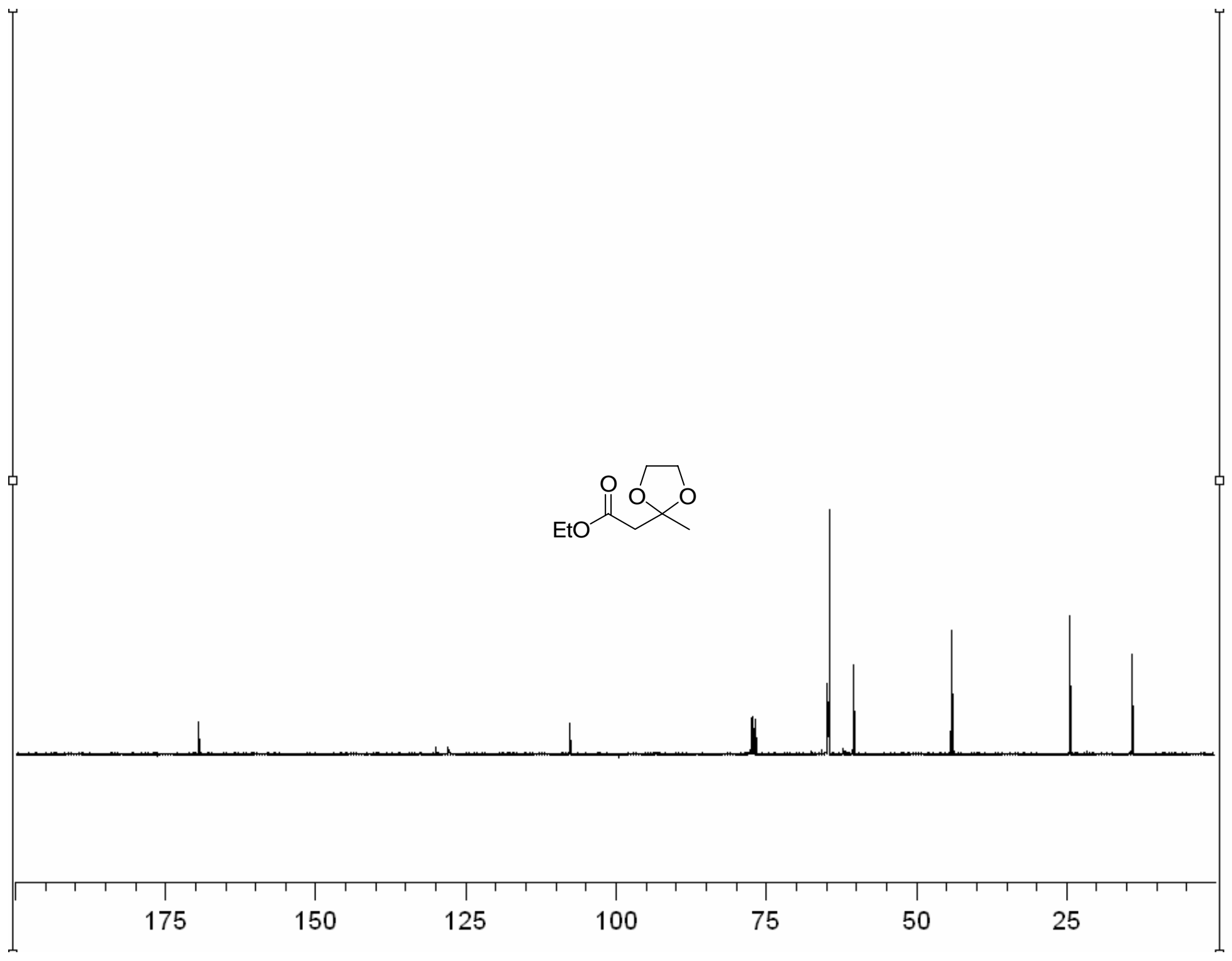


Ciufolini, M.A., et al.

Synthesis of Topopyrones B and D

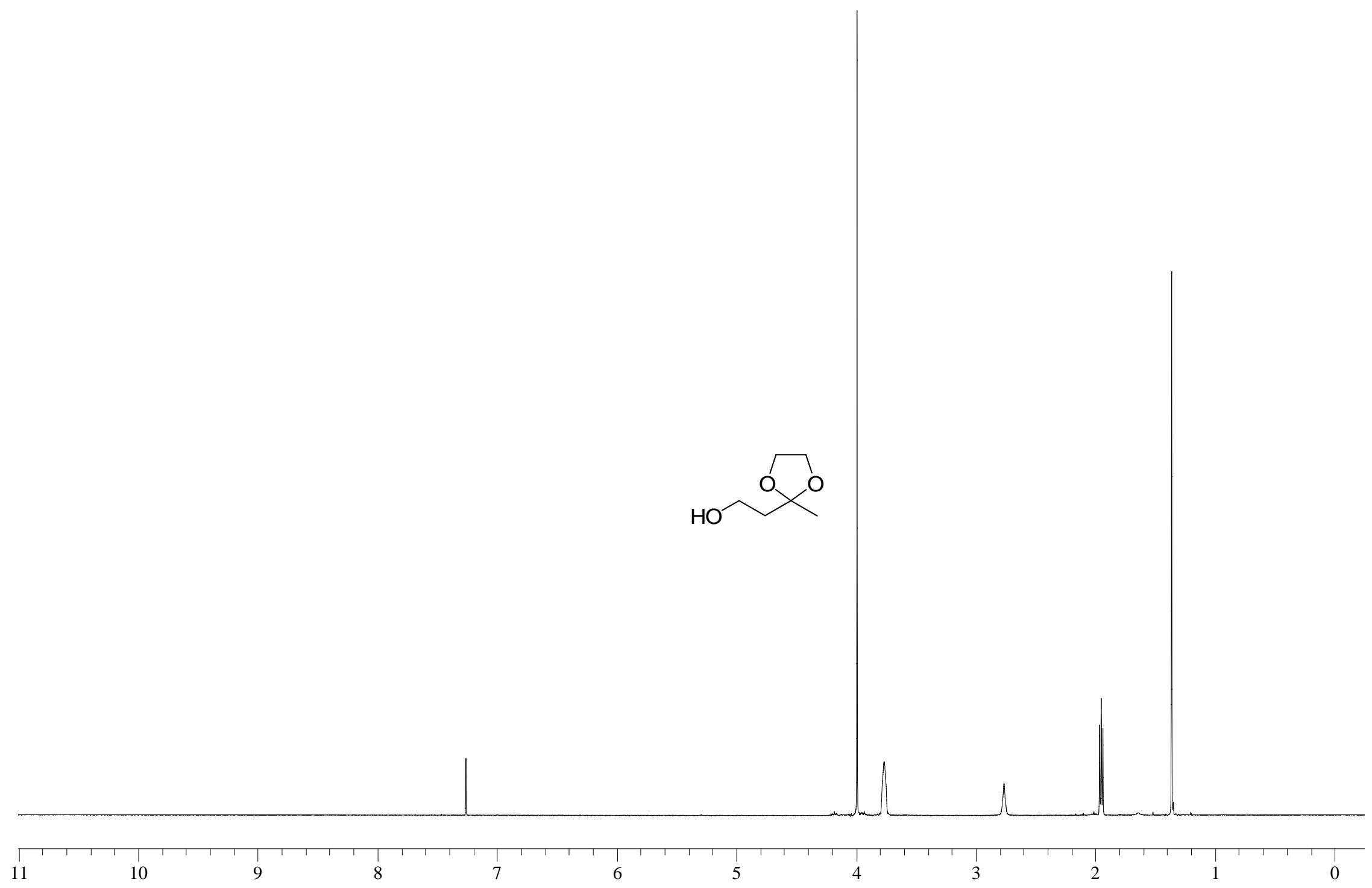


Ciufolini, M.A., et al.

Synthesis of Topopyrones B and D

S 15

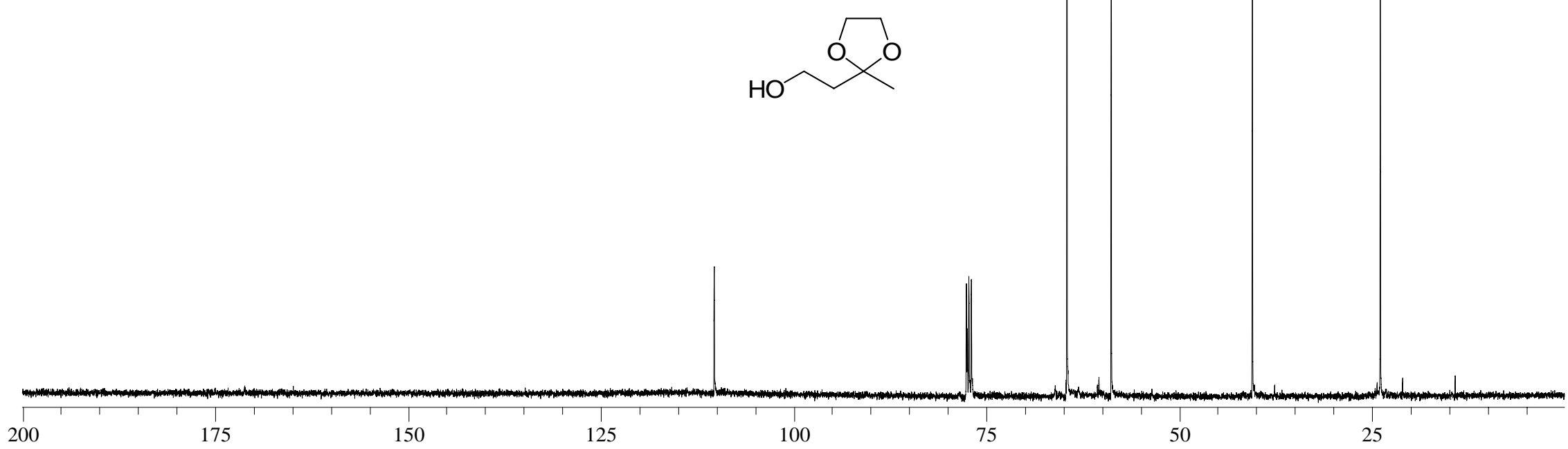




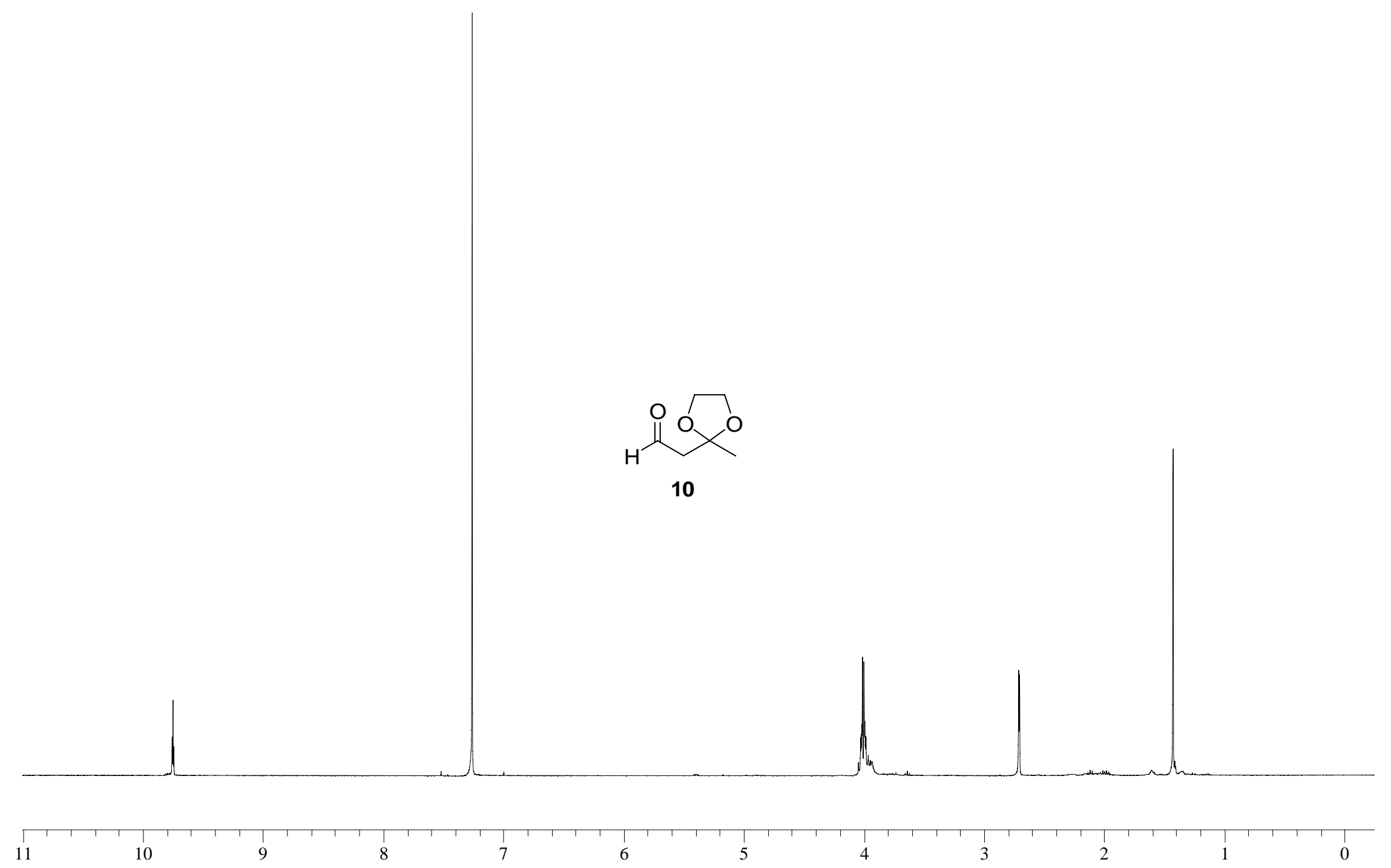




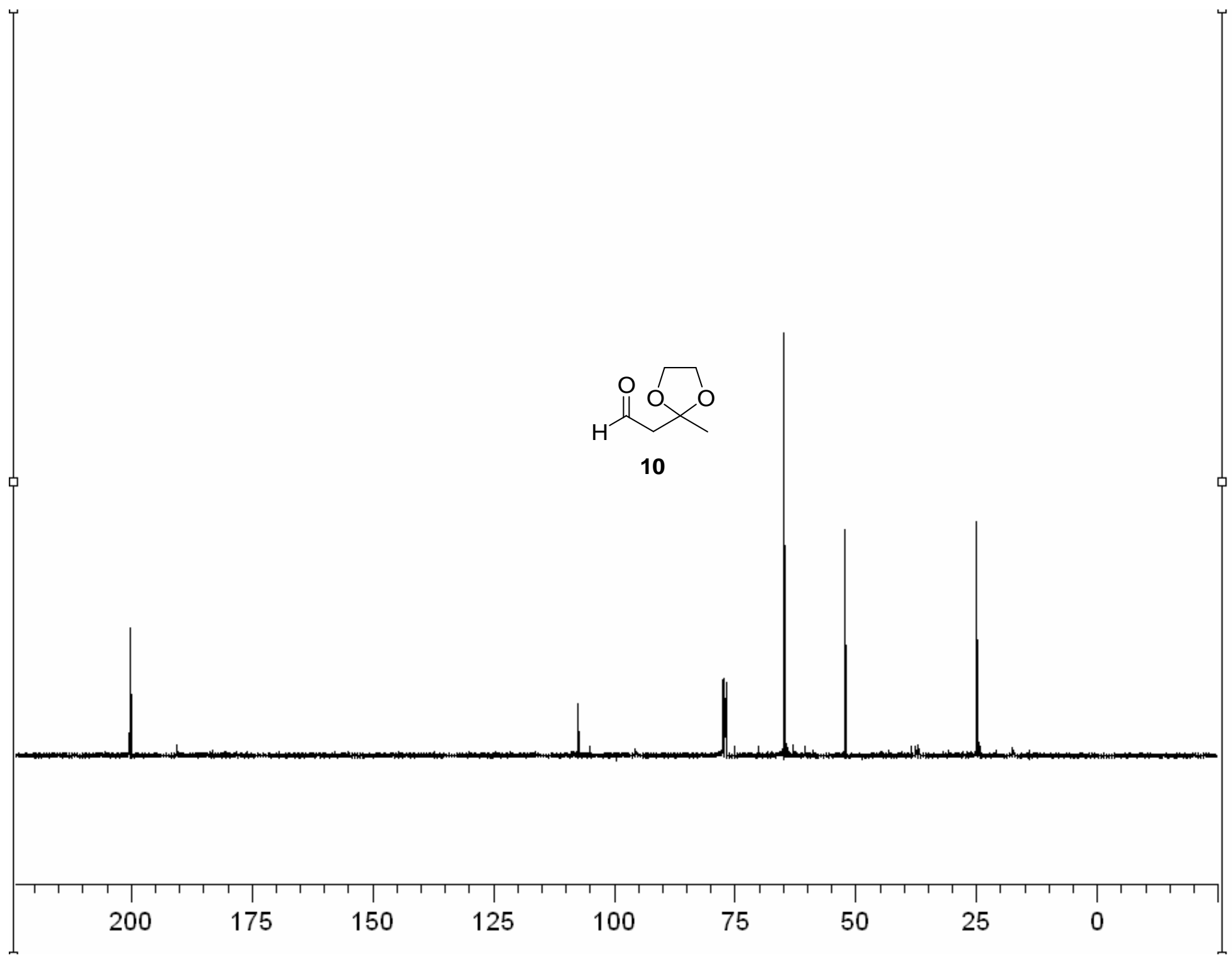




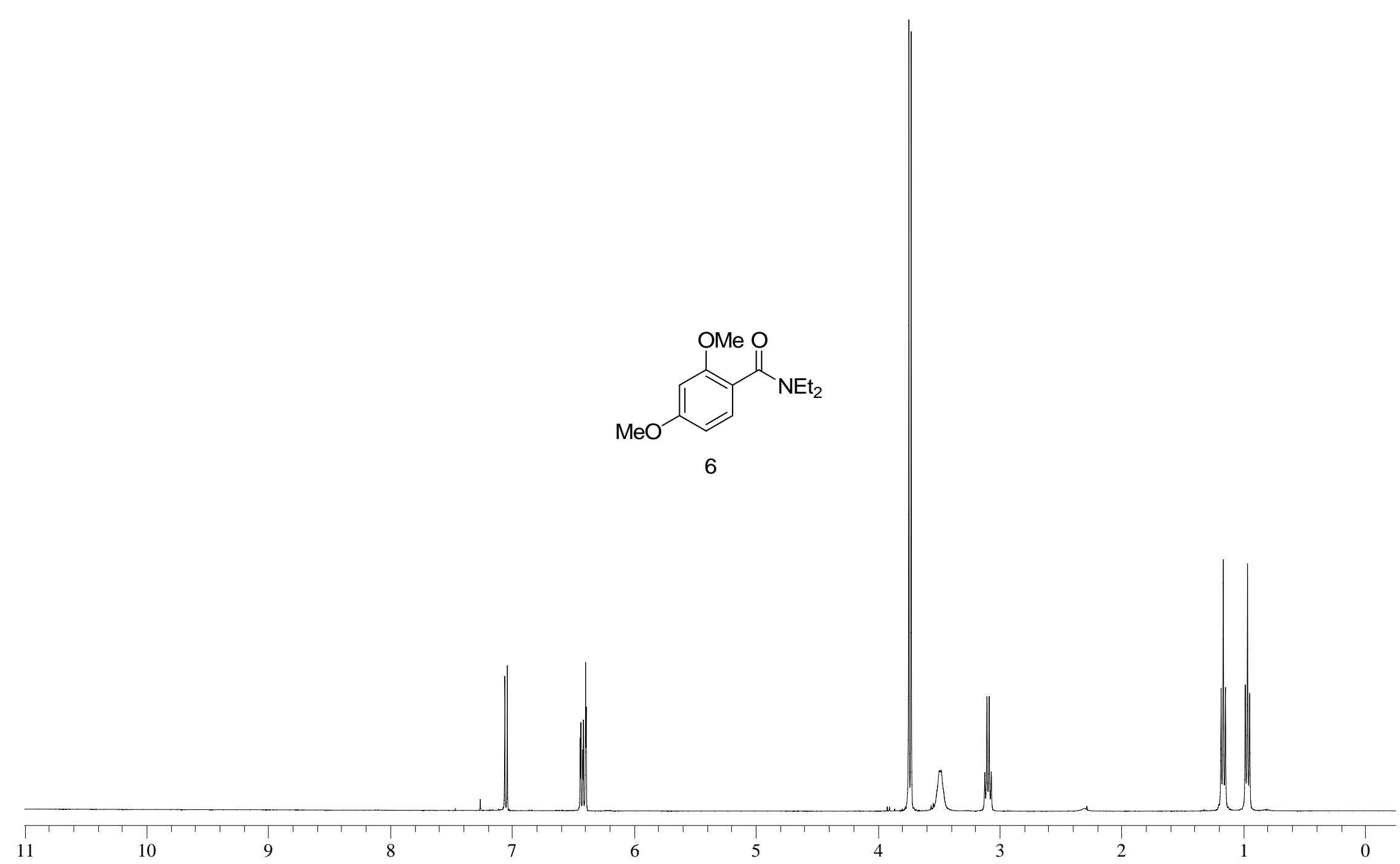




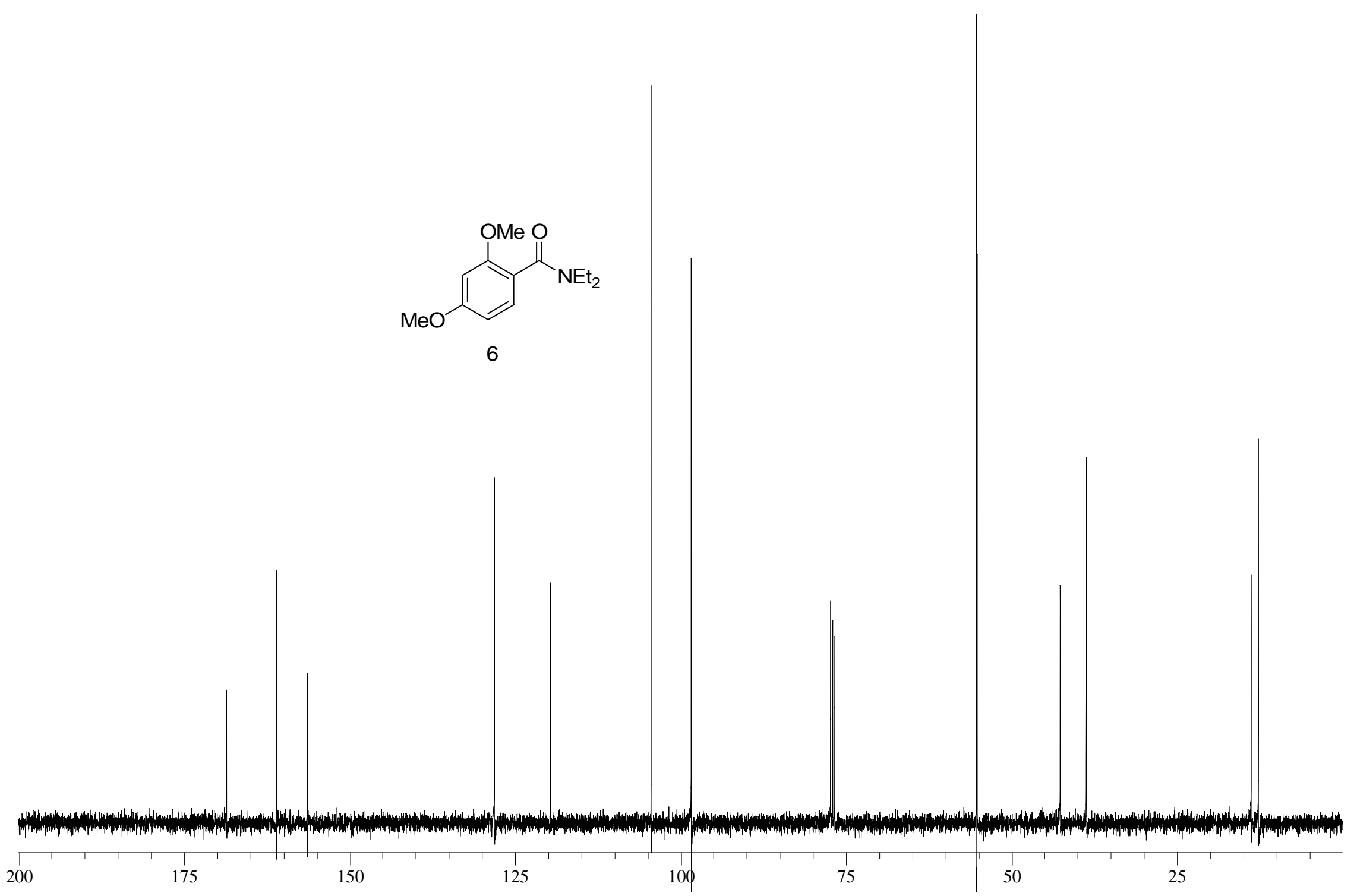



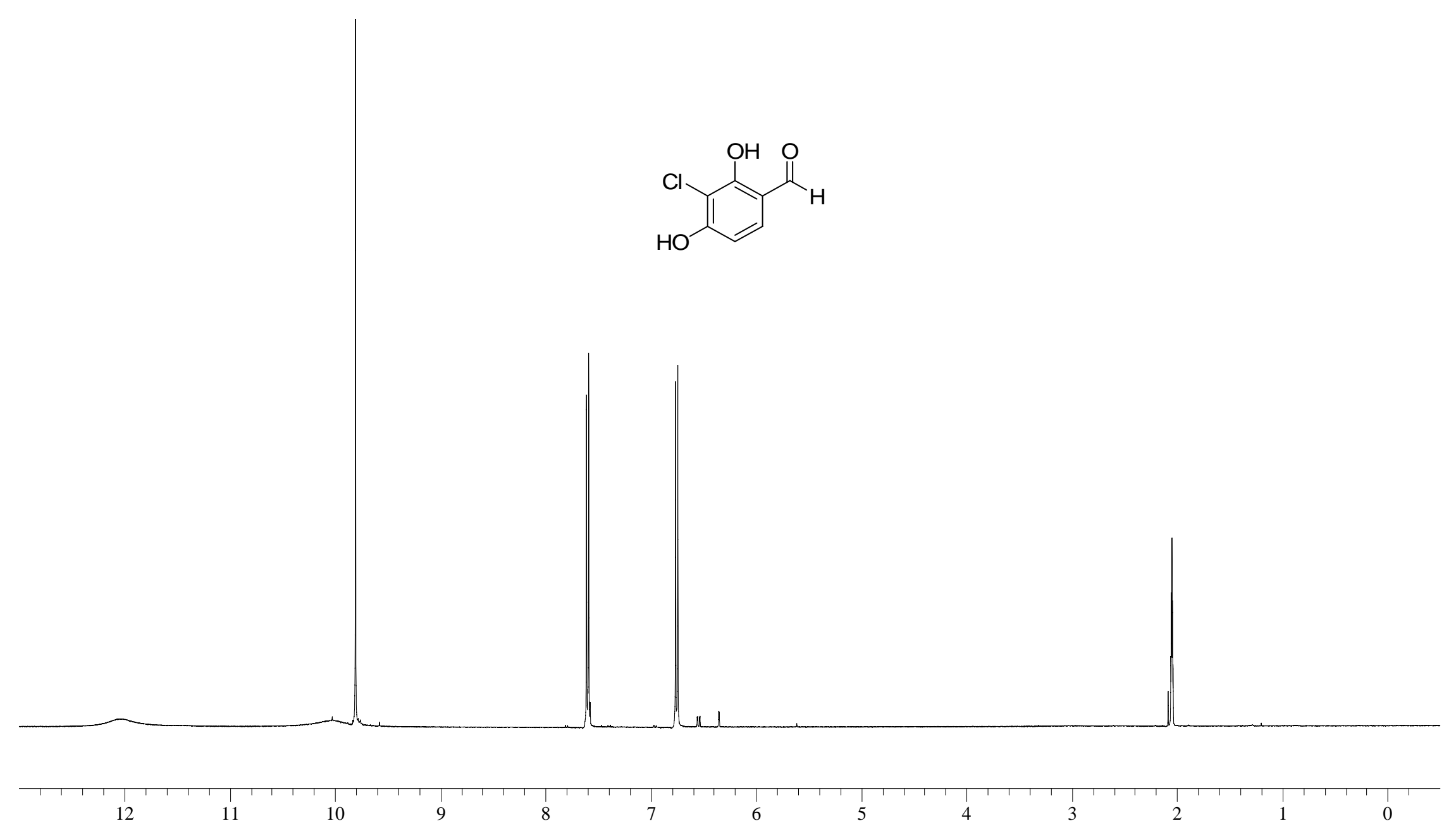
Ciufolini, M.A., et al.

Synthesis of Topopyrones B and D

S 21

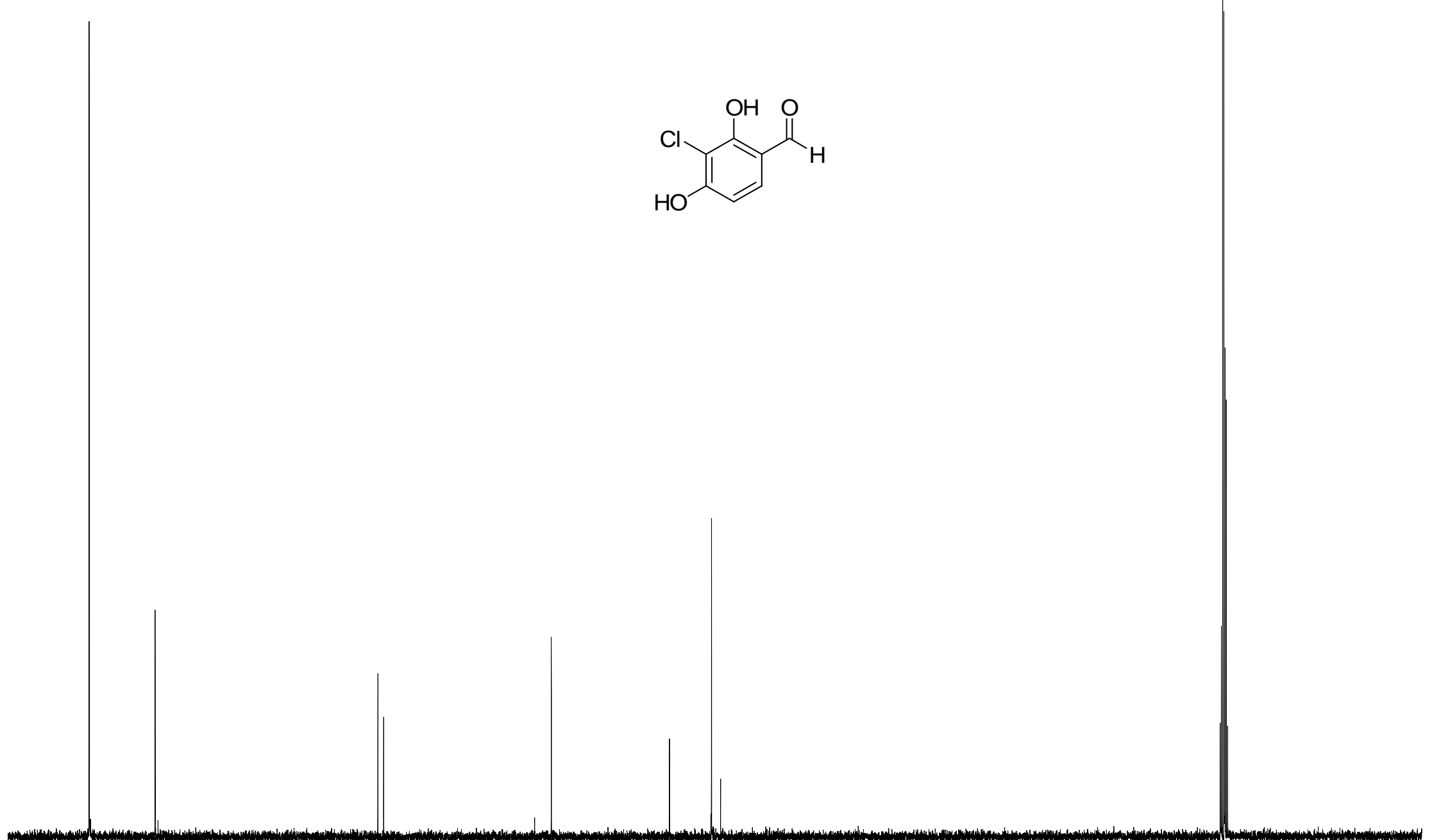




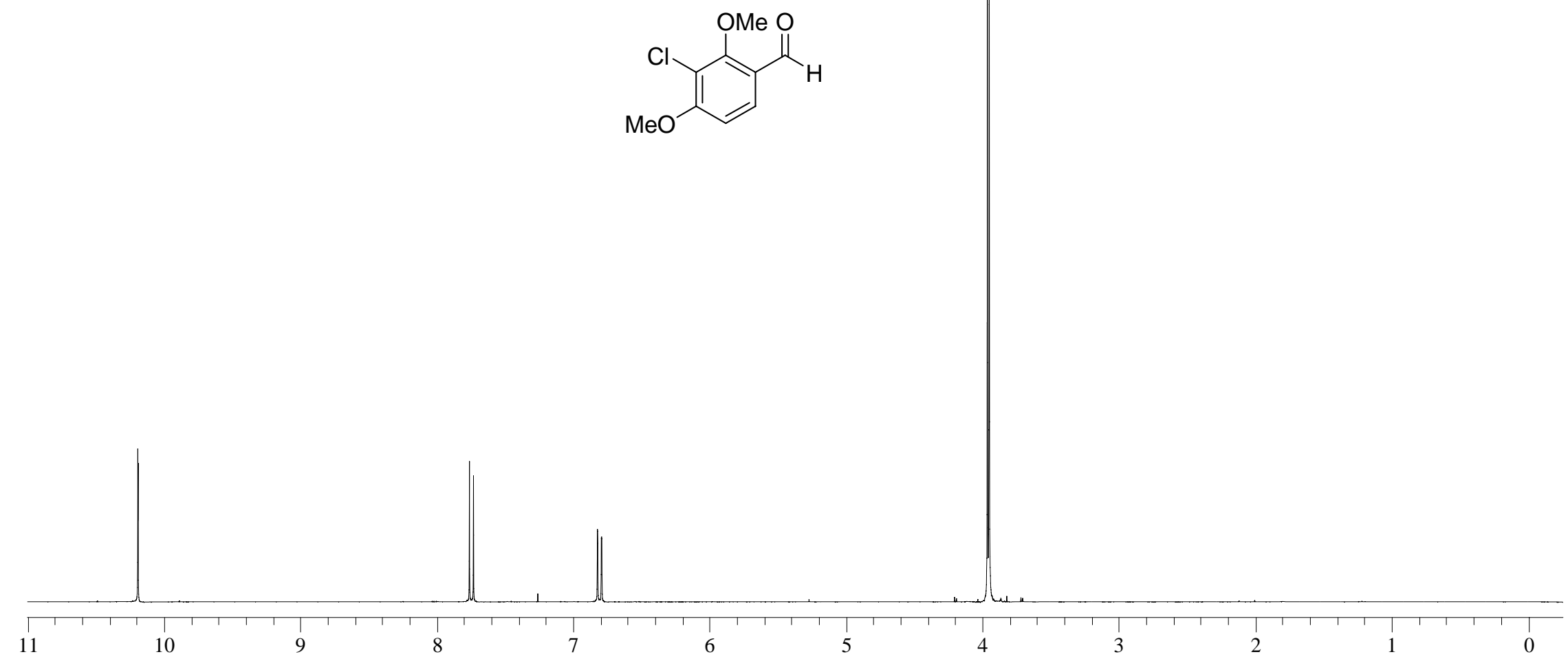




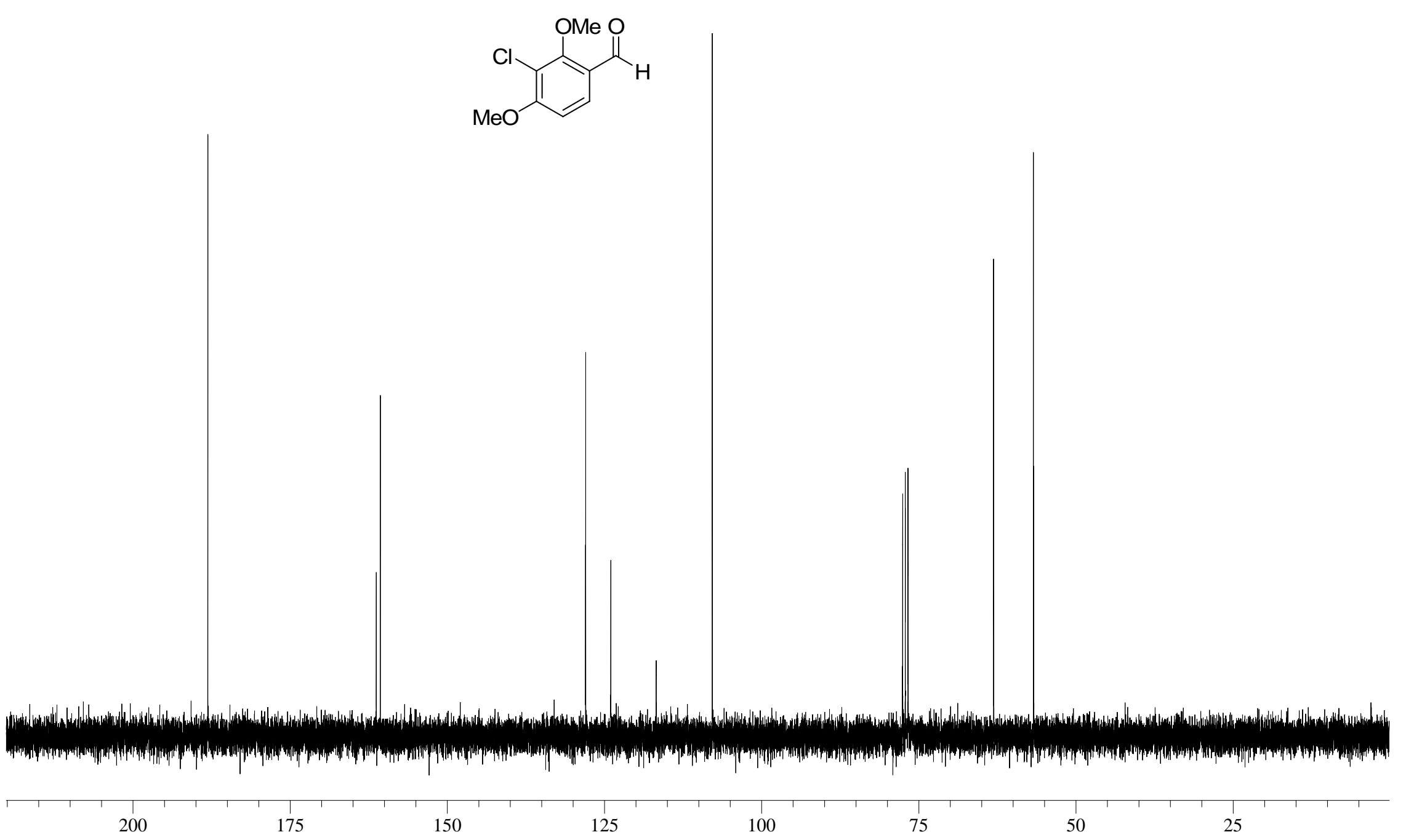




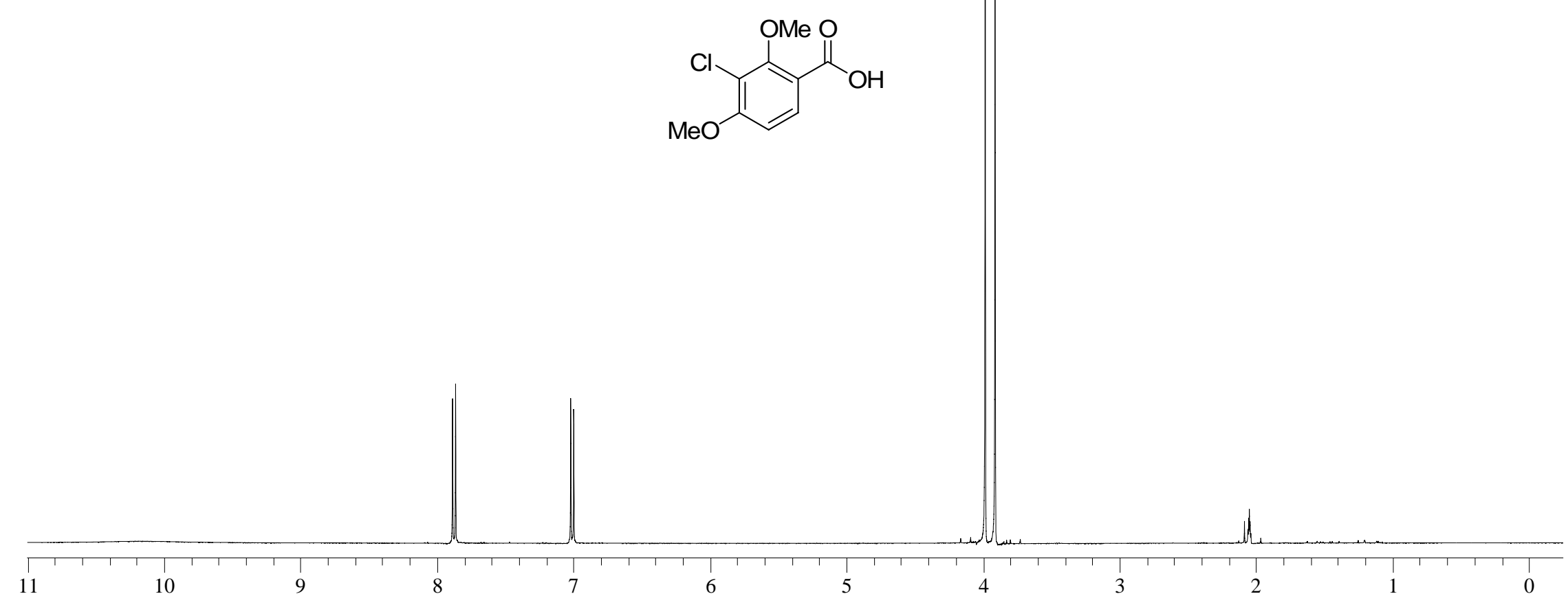




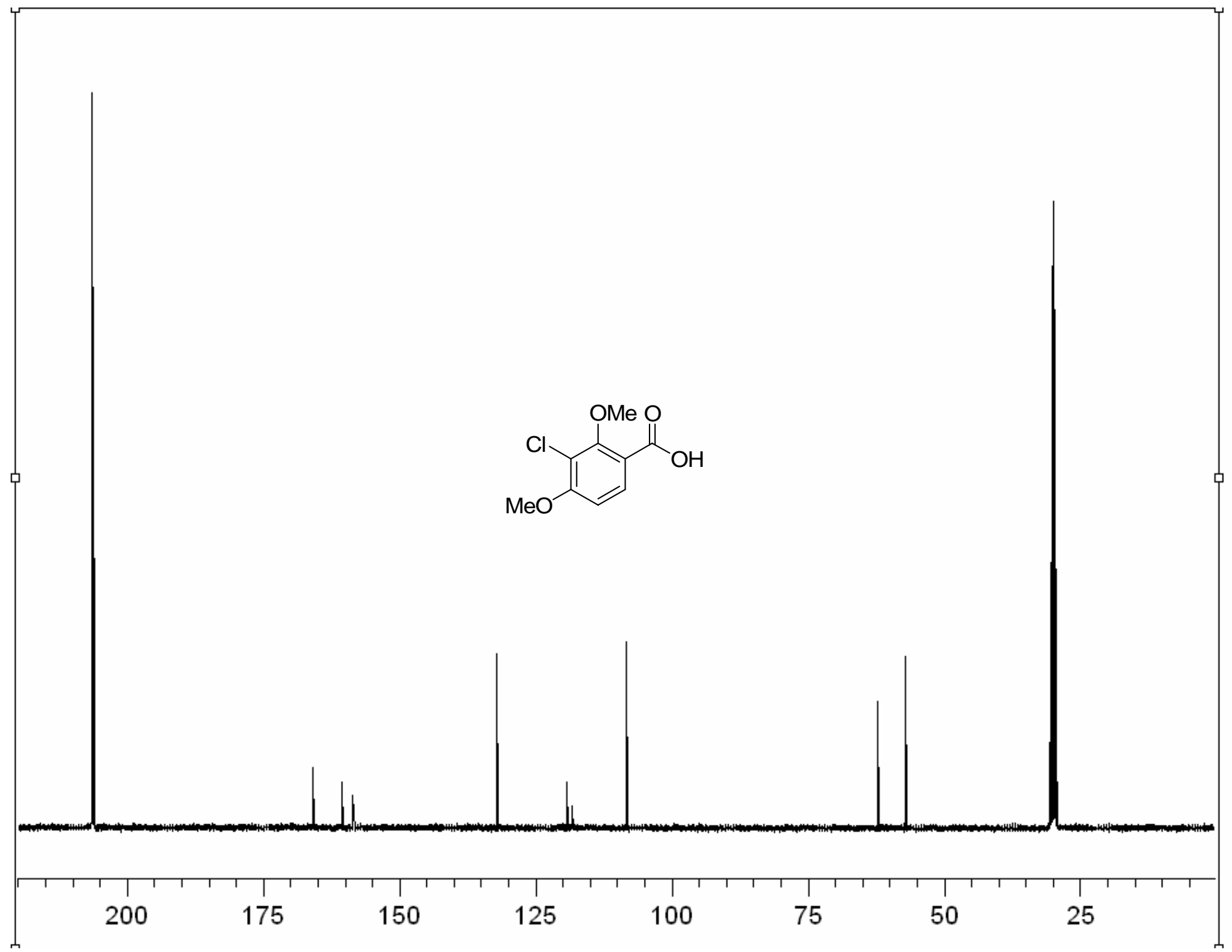




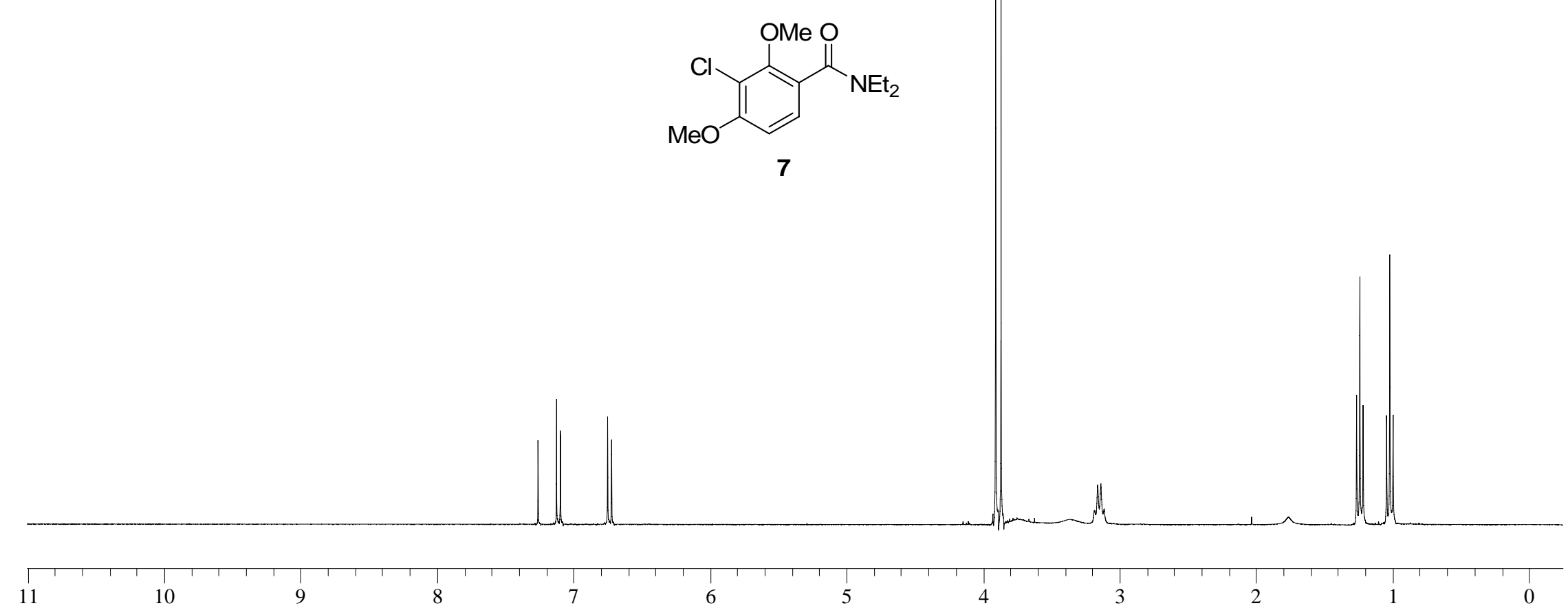




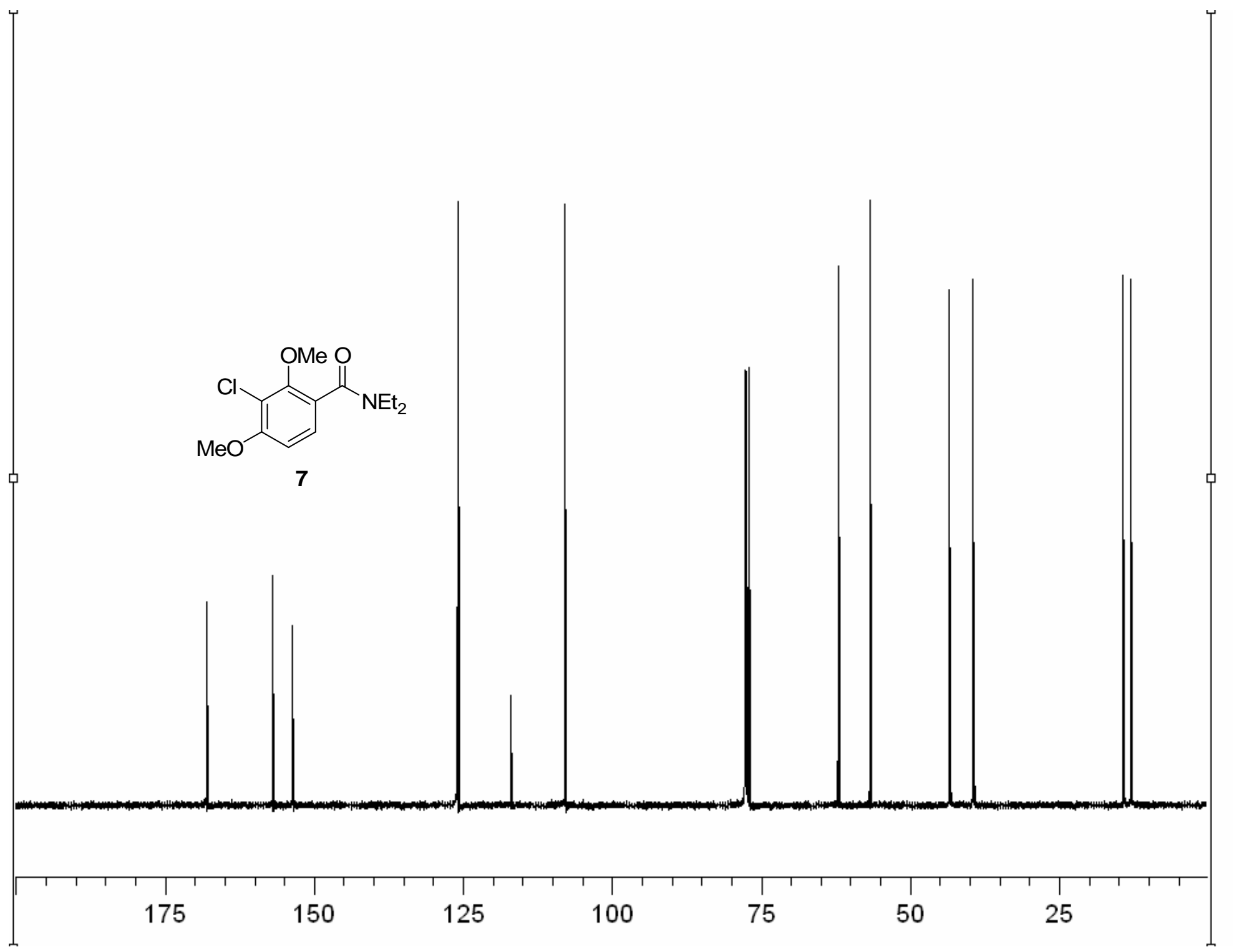




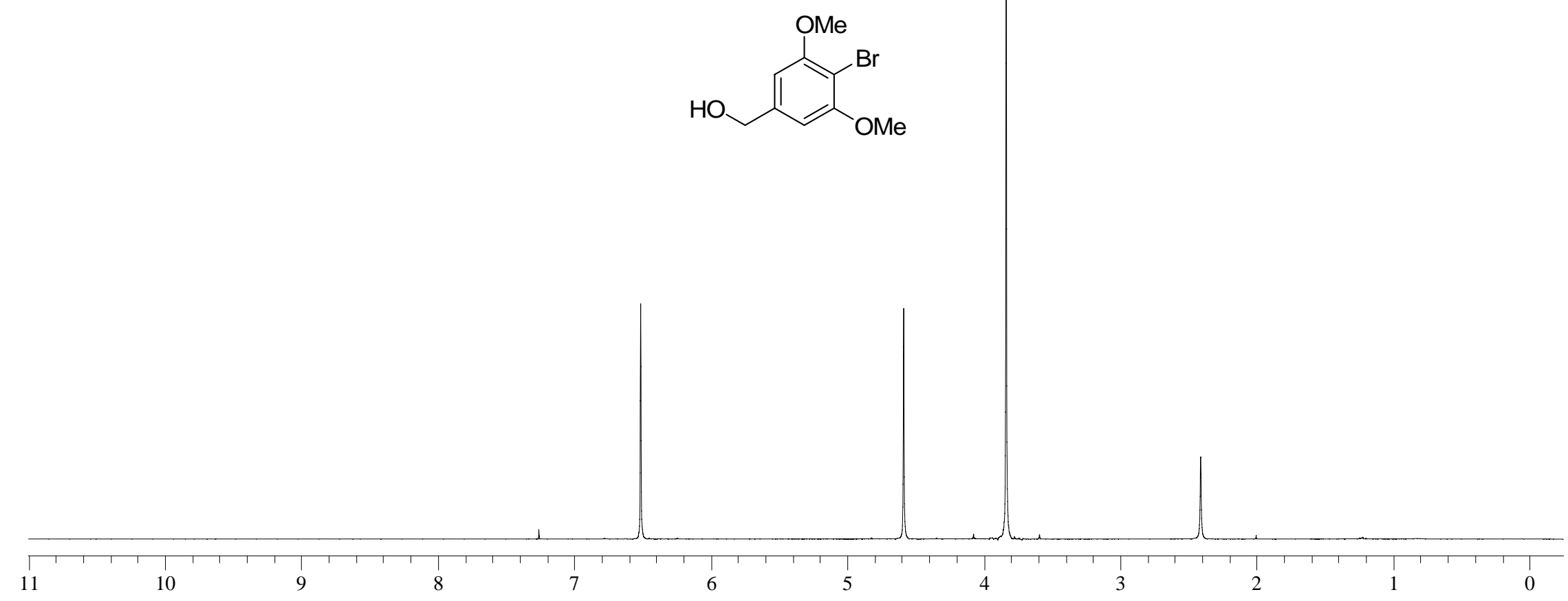




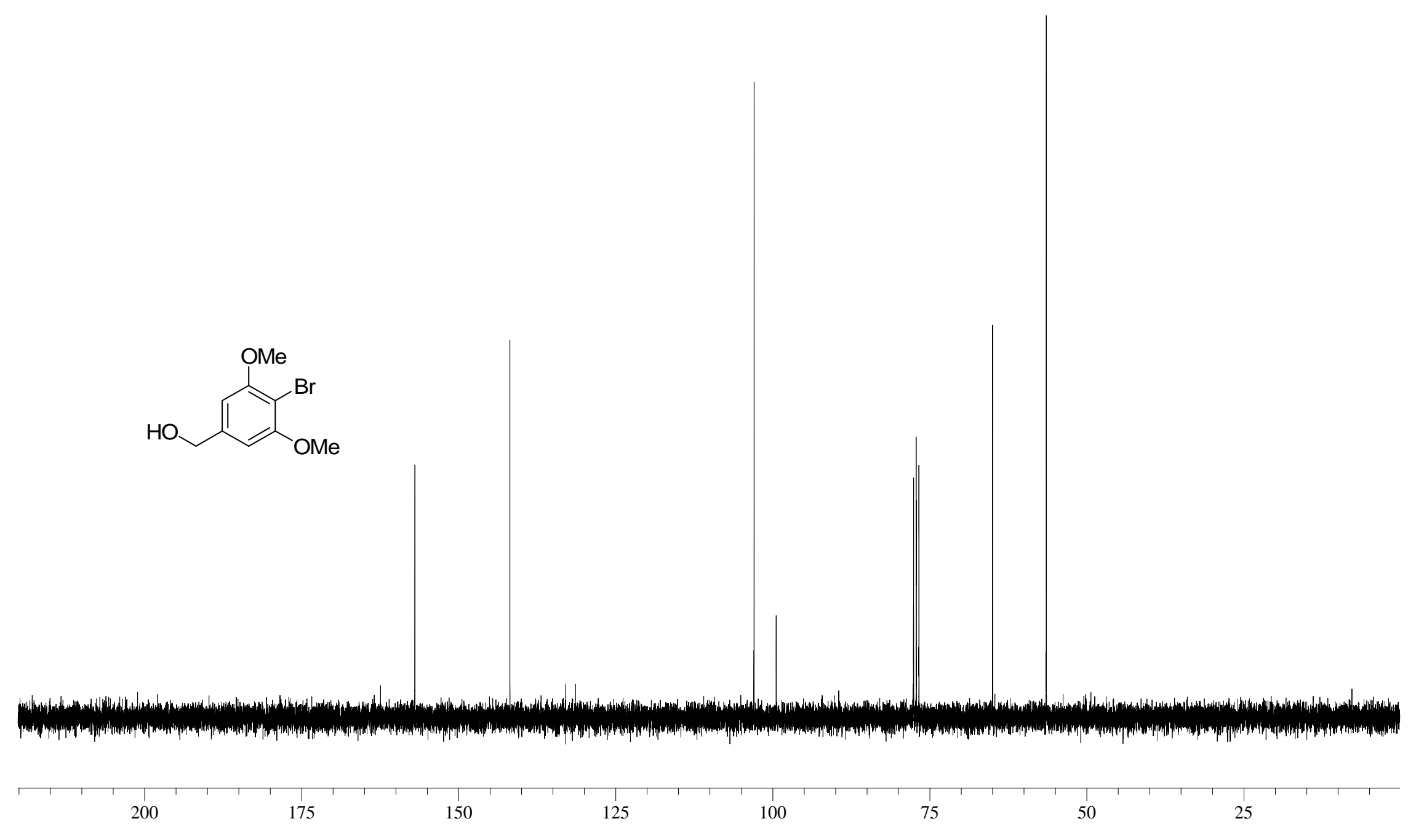




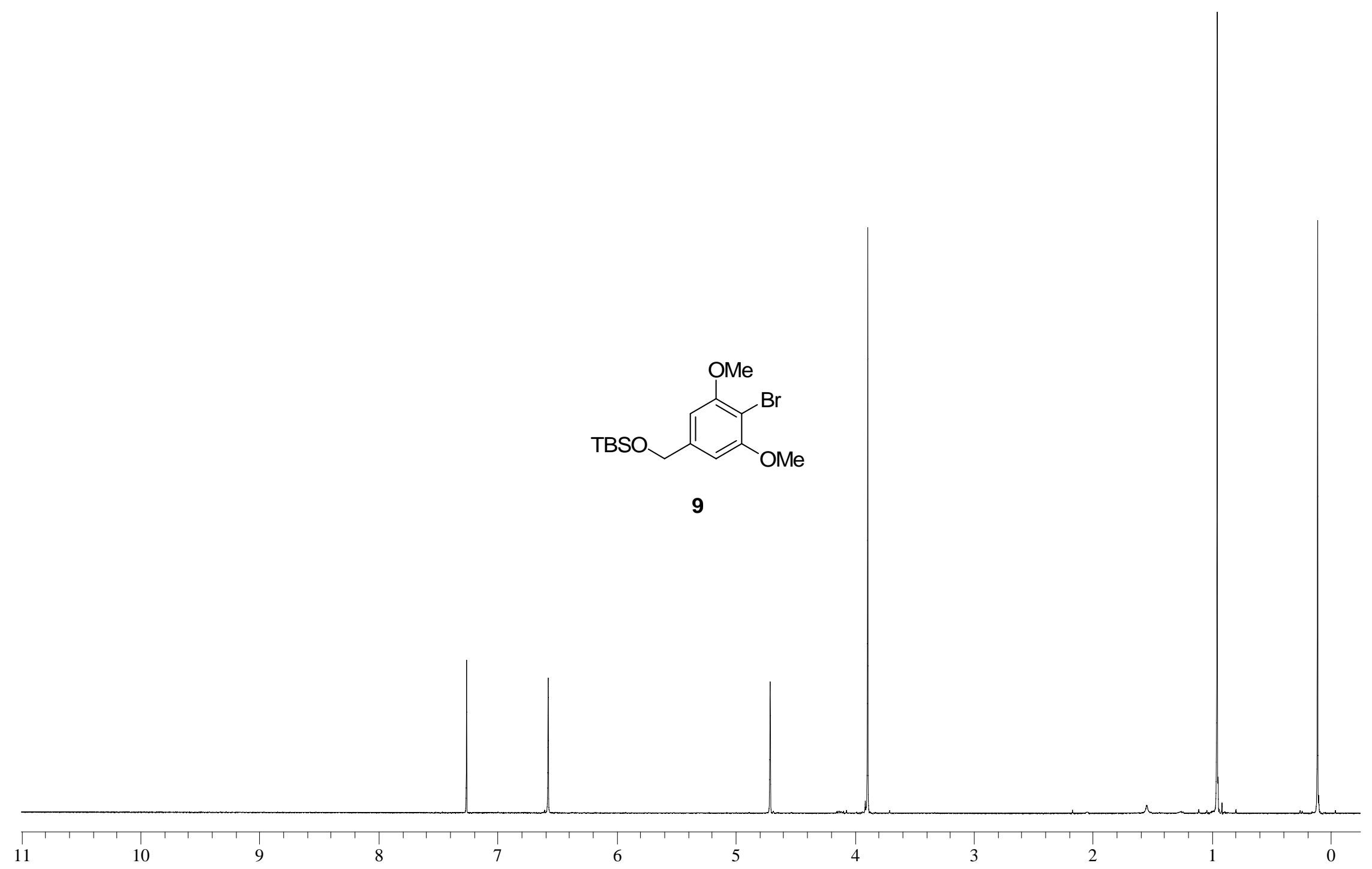




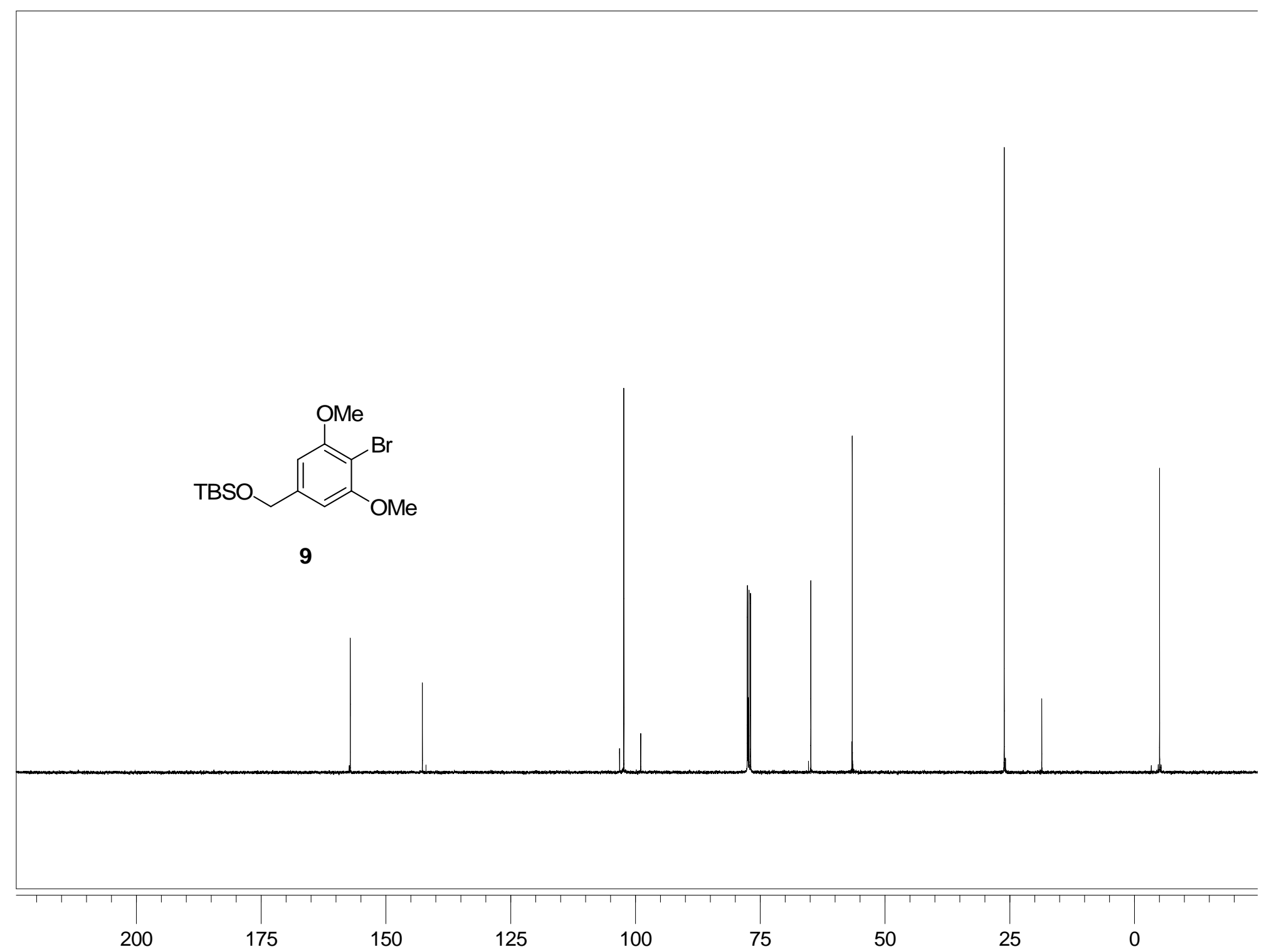




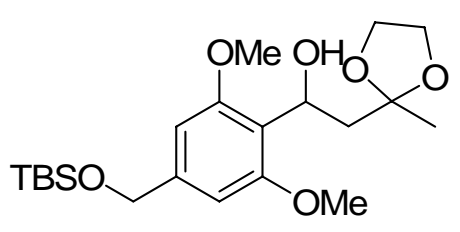

11

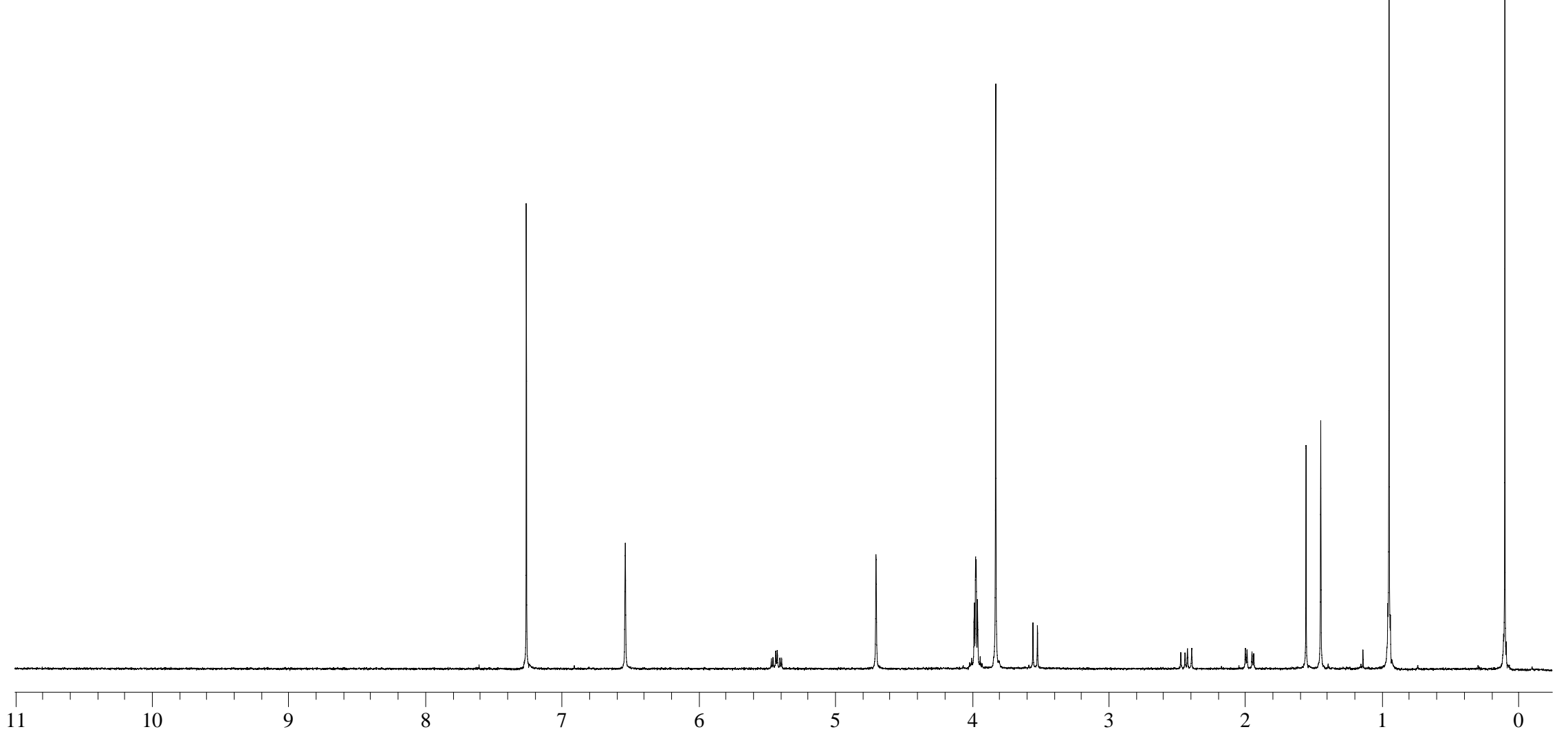




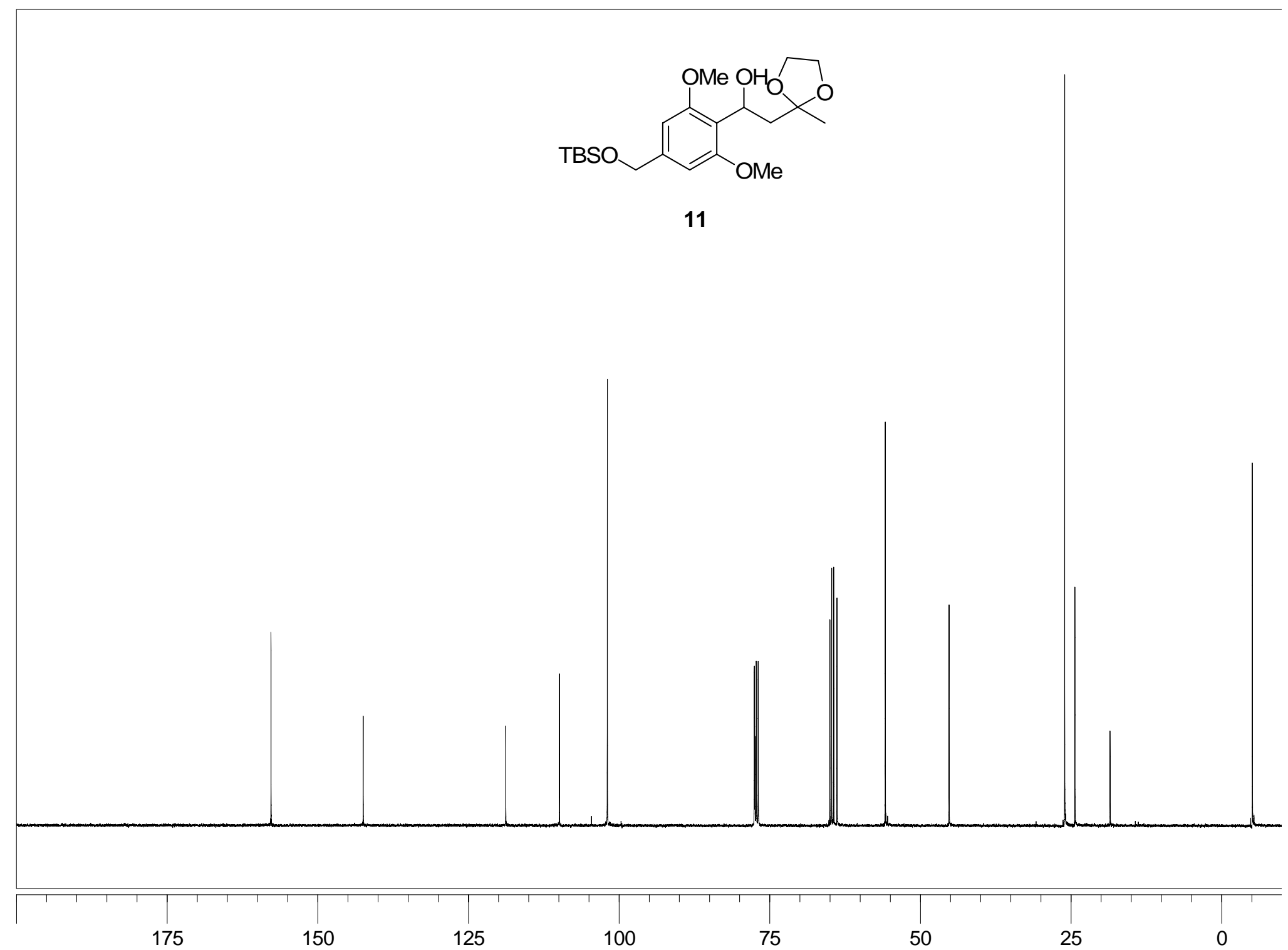



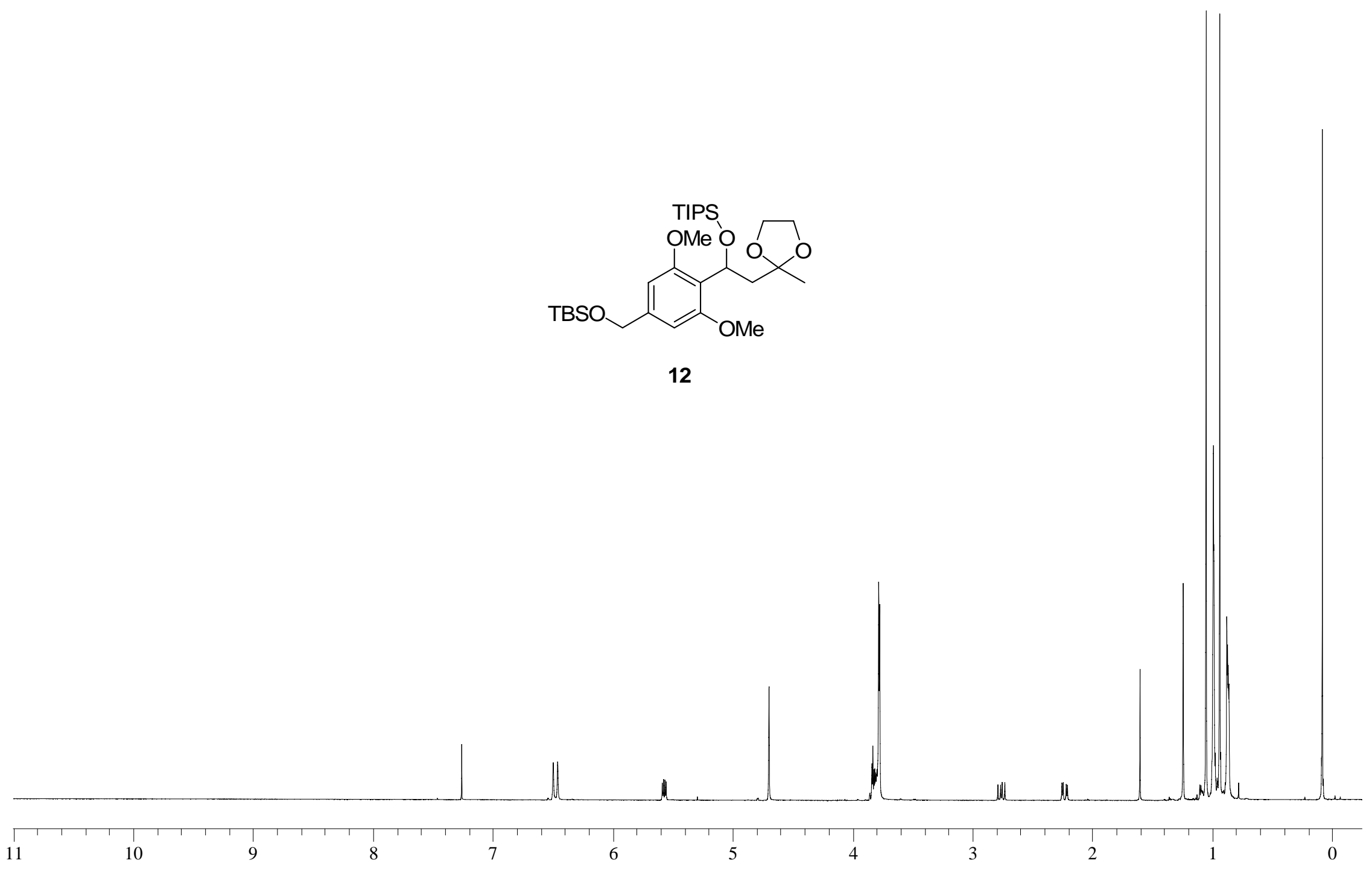

3 


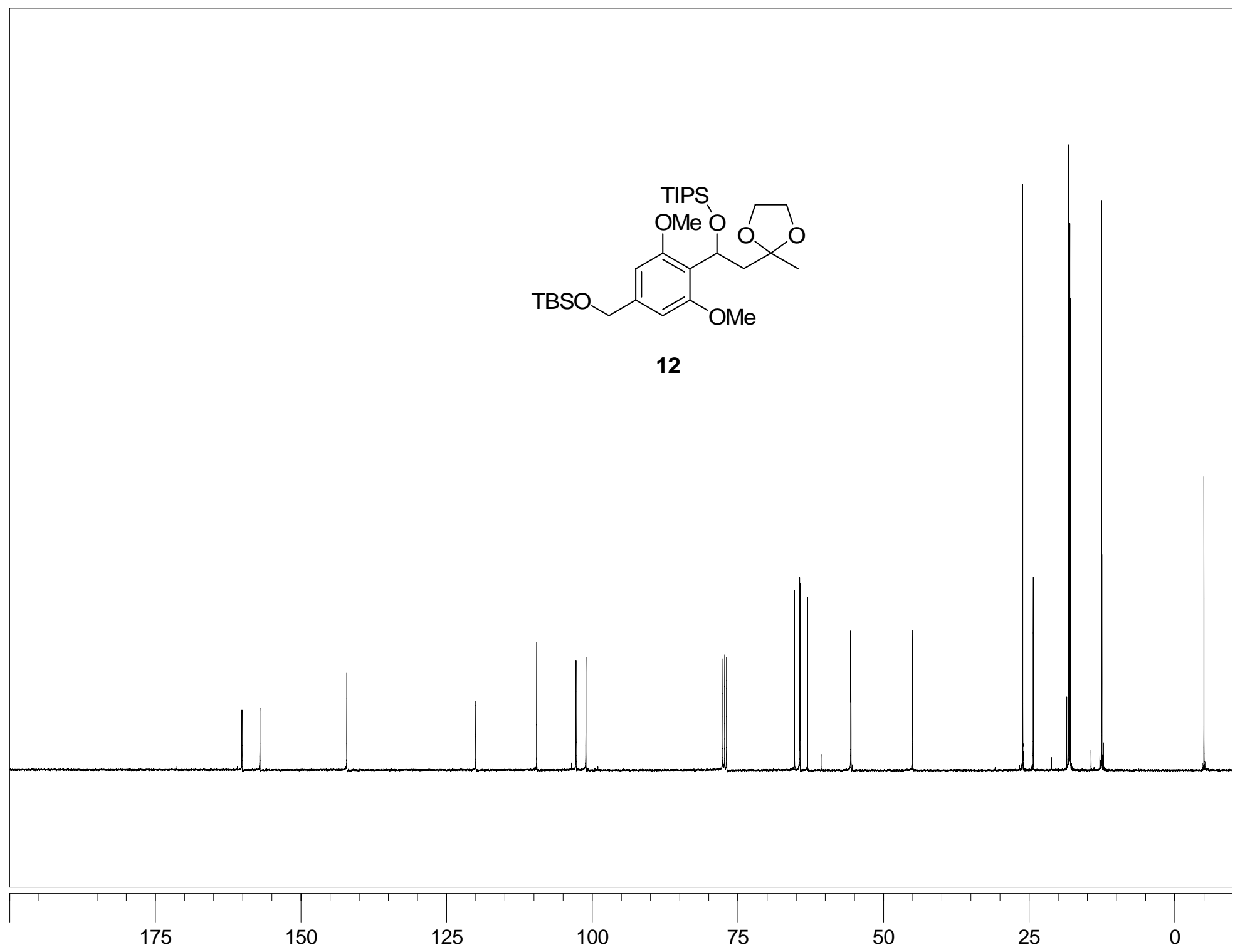



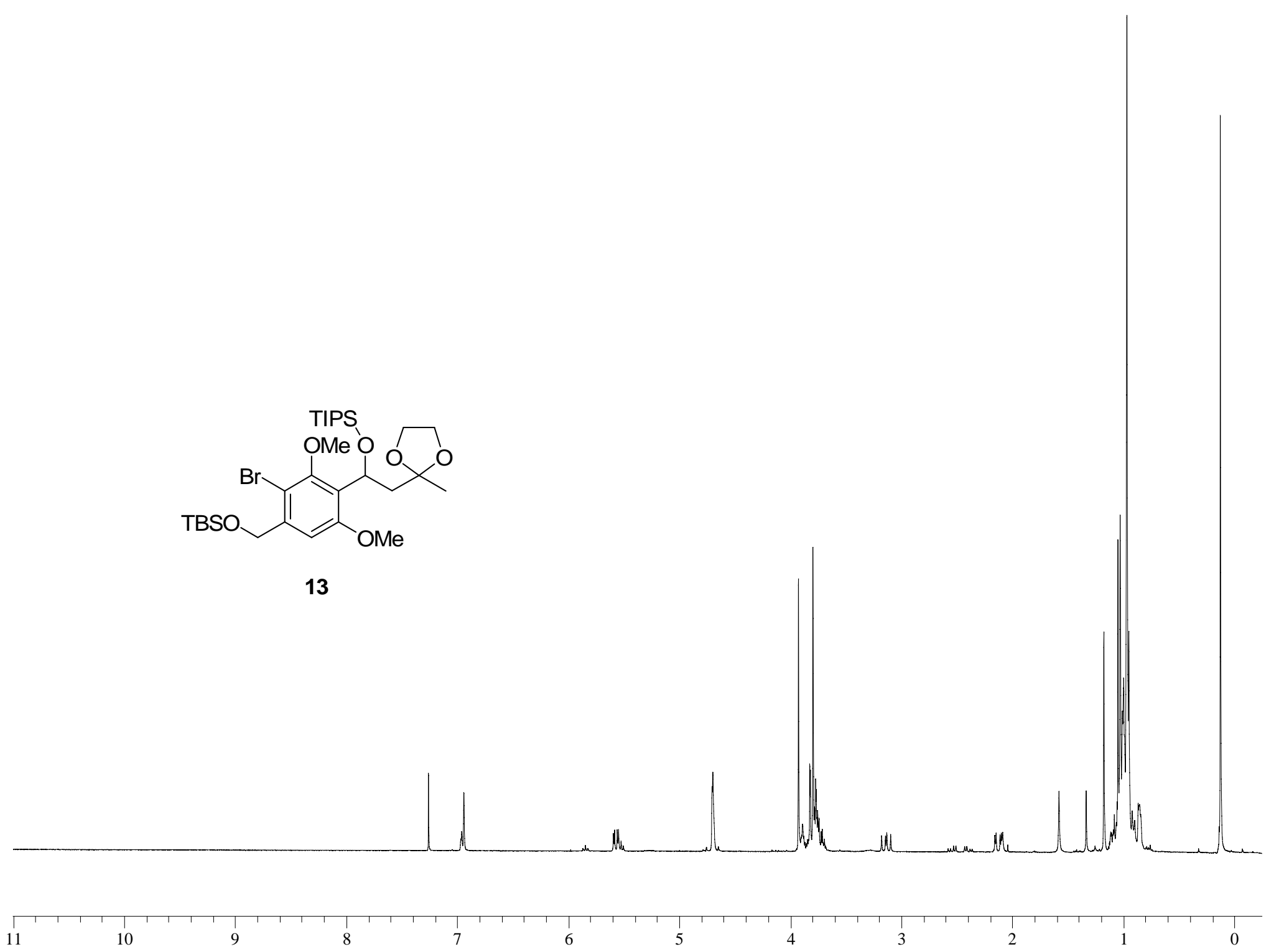


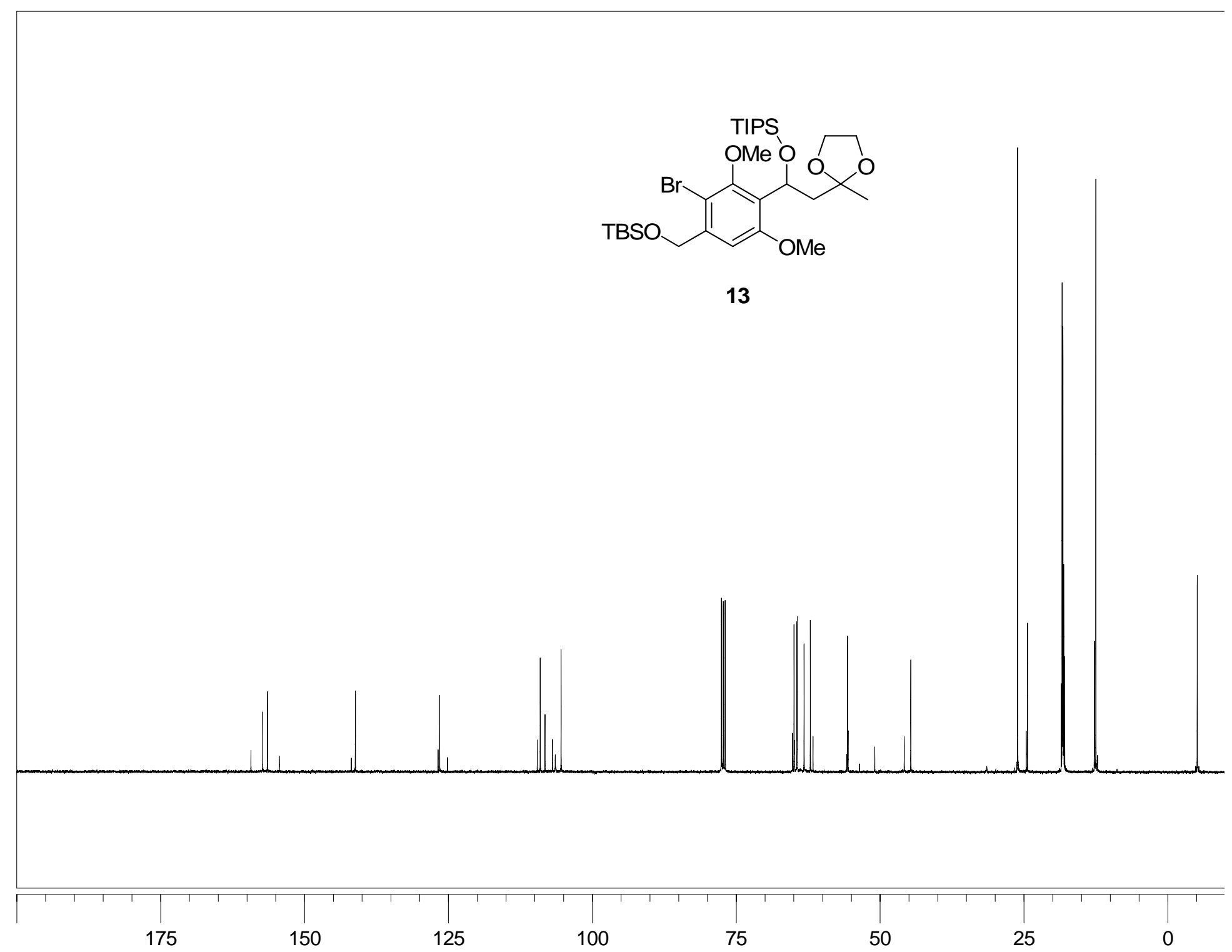




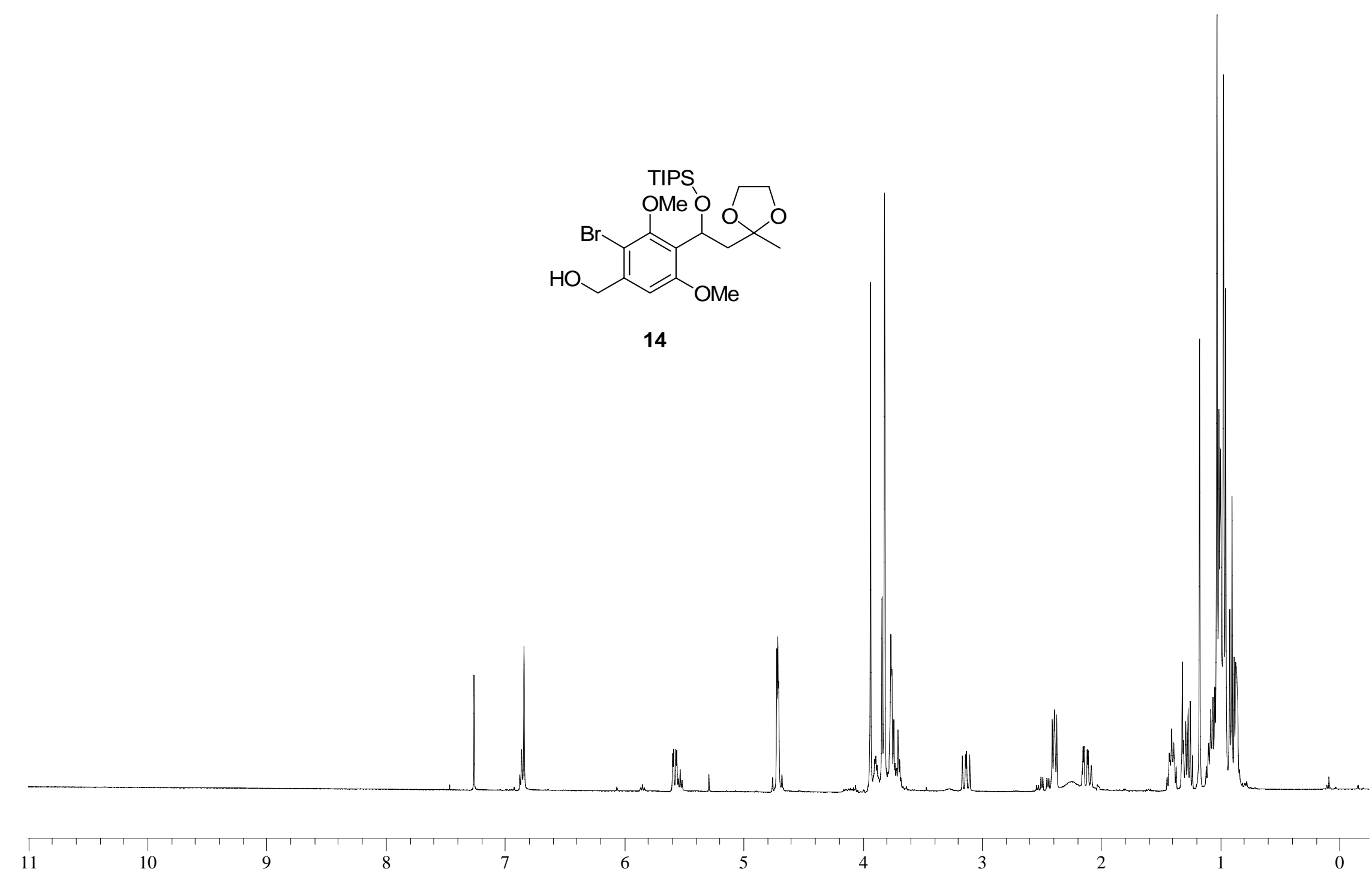




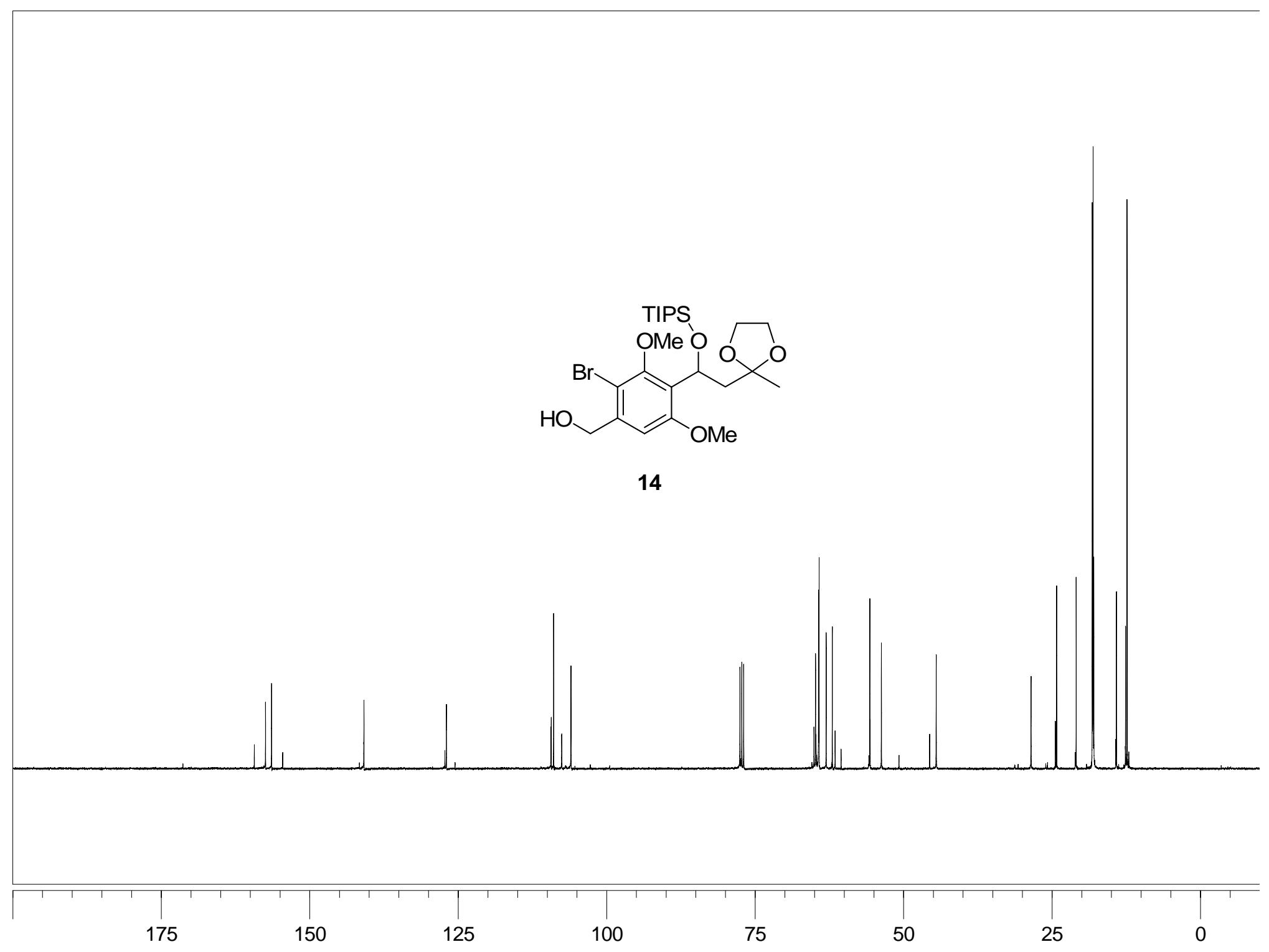




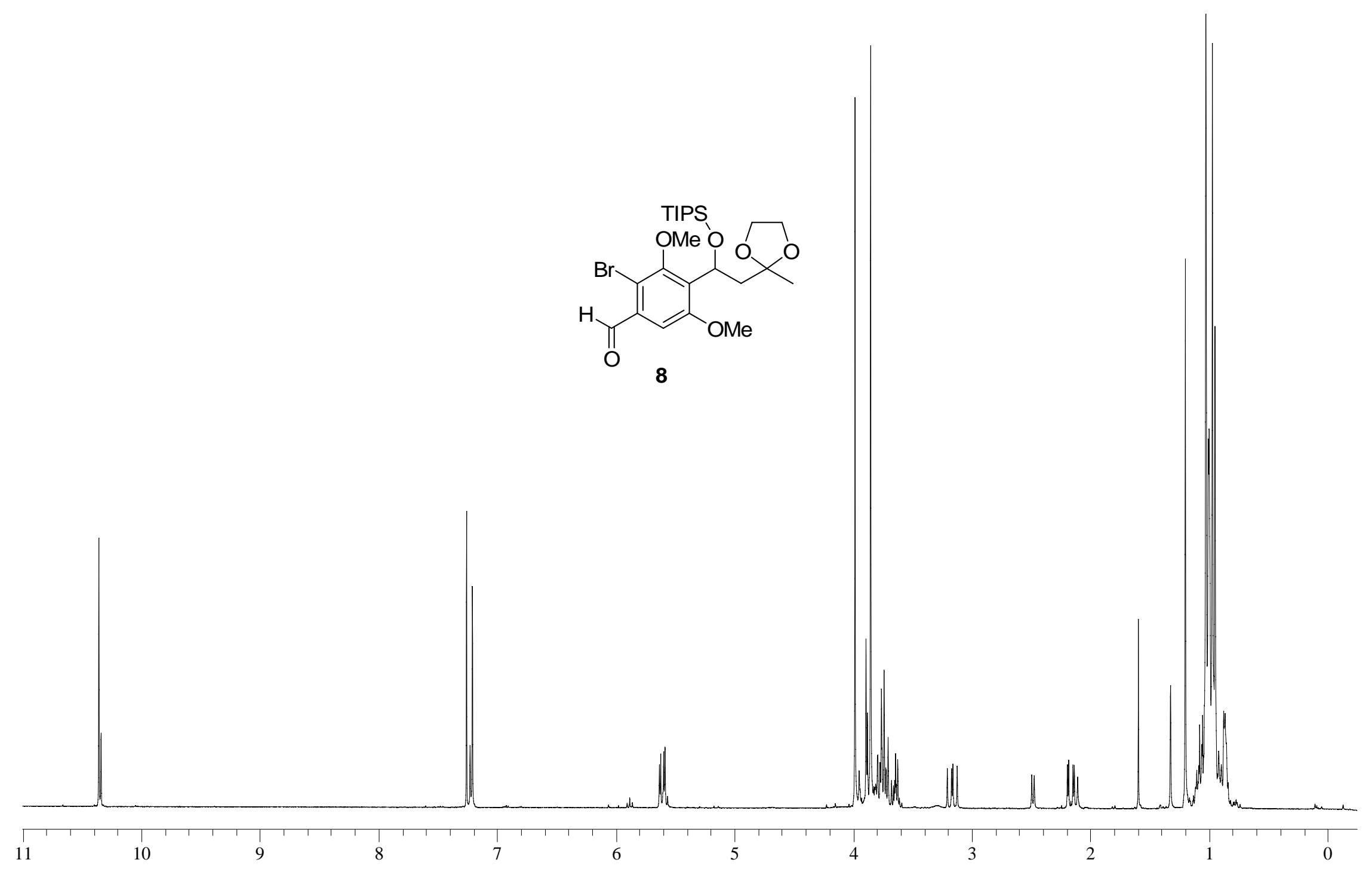




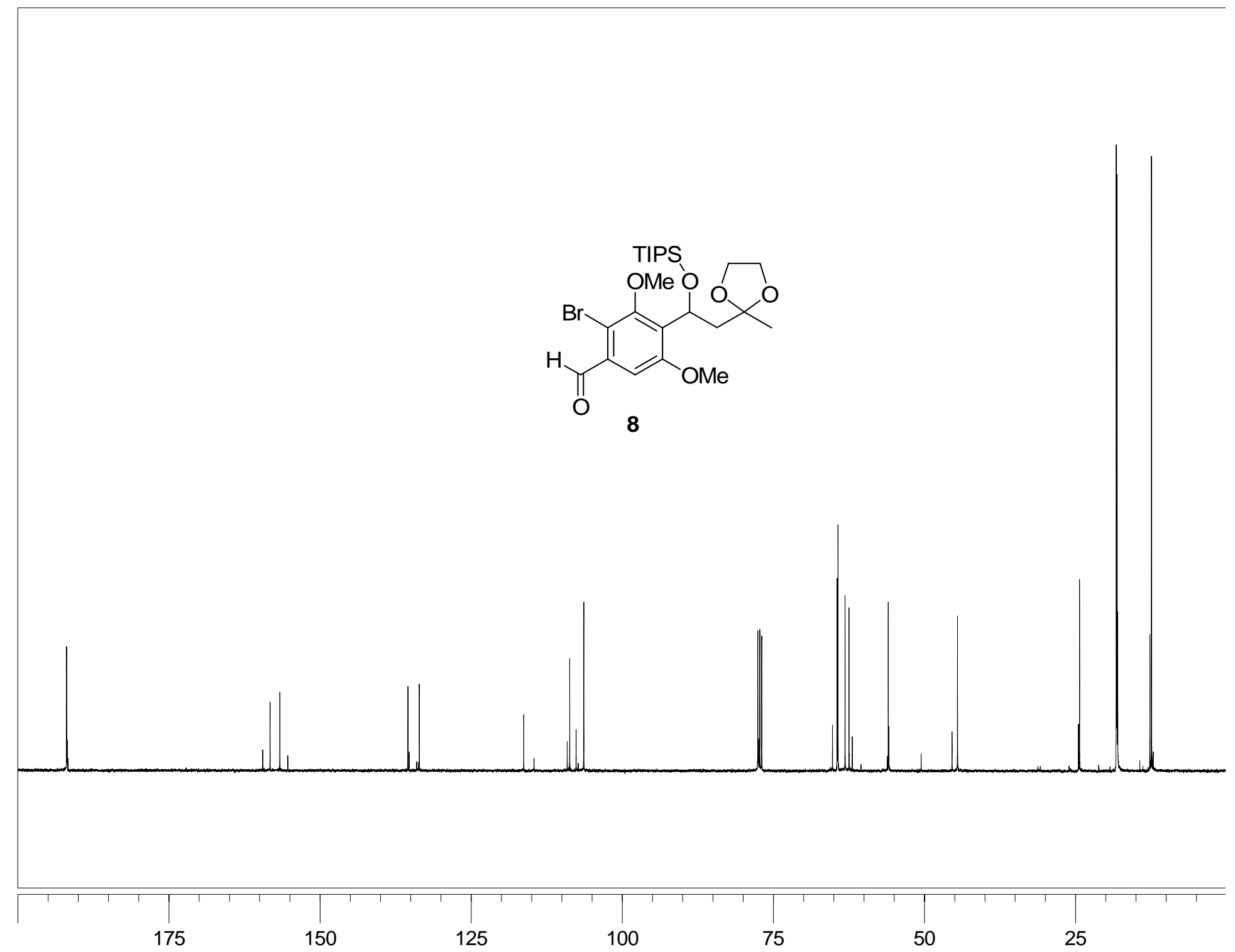




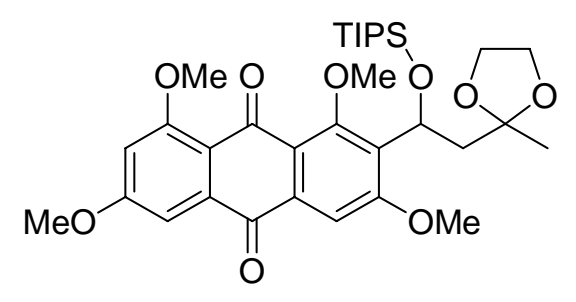

17

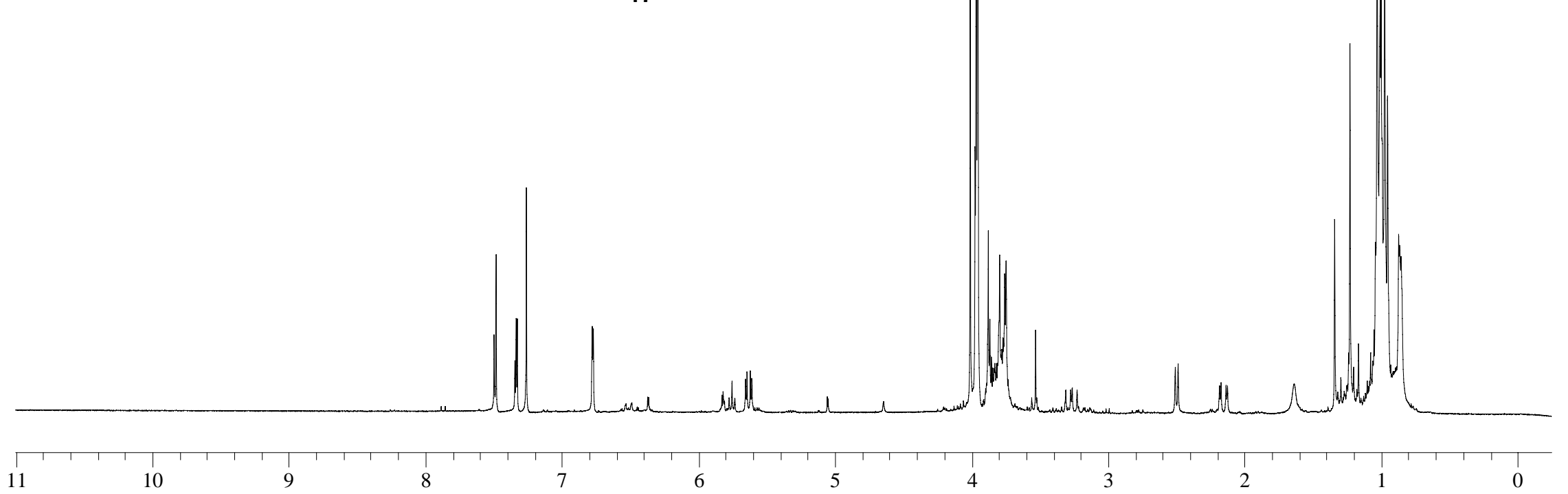




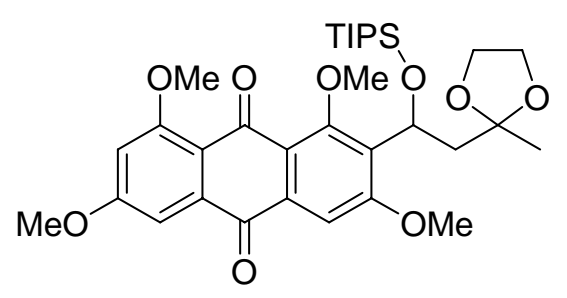

17

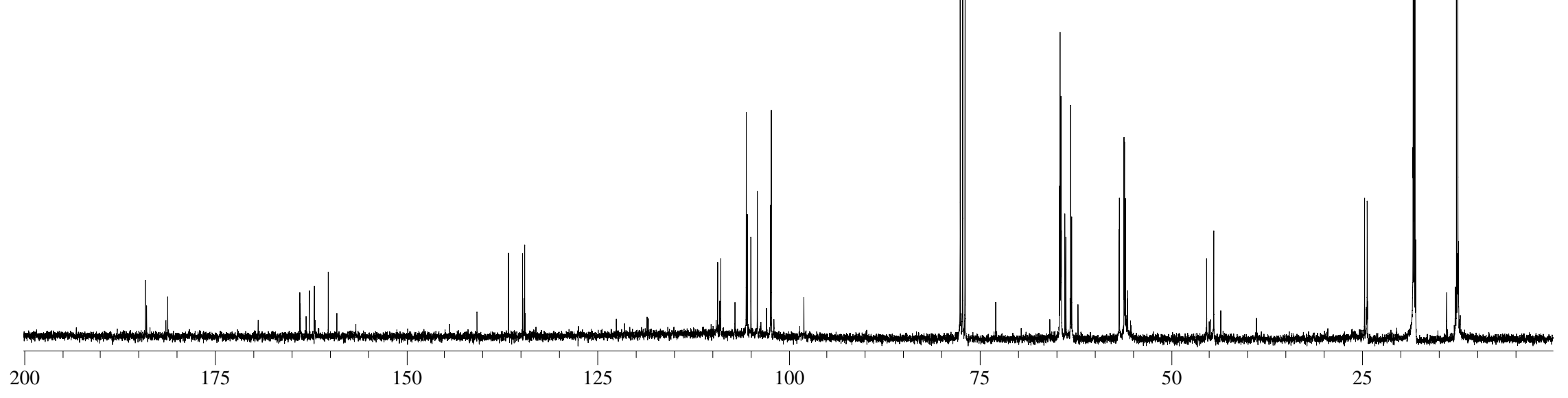




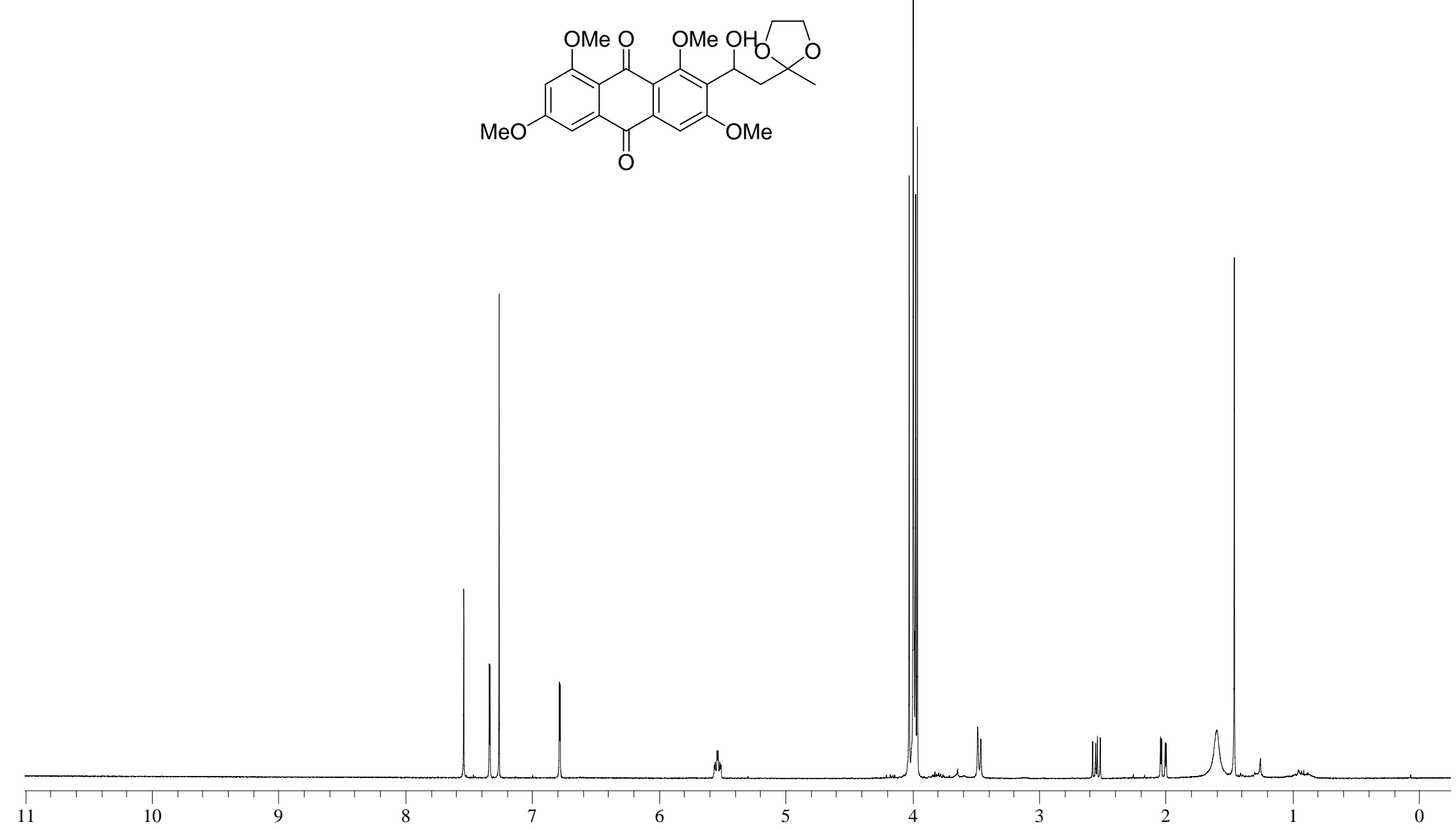




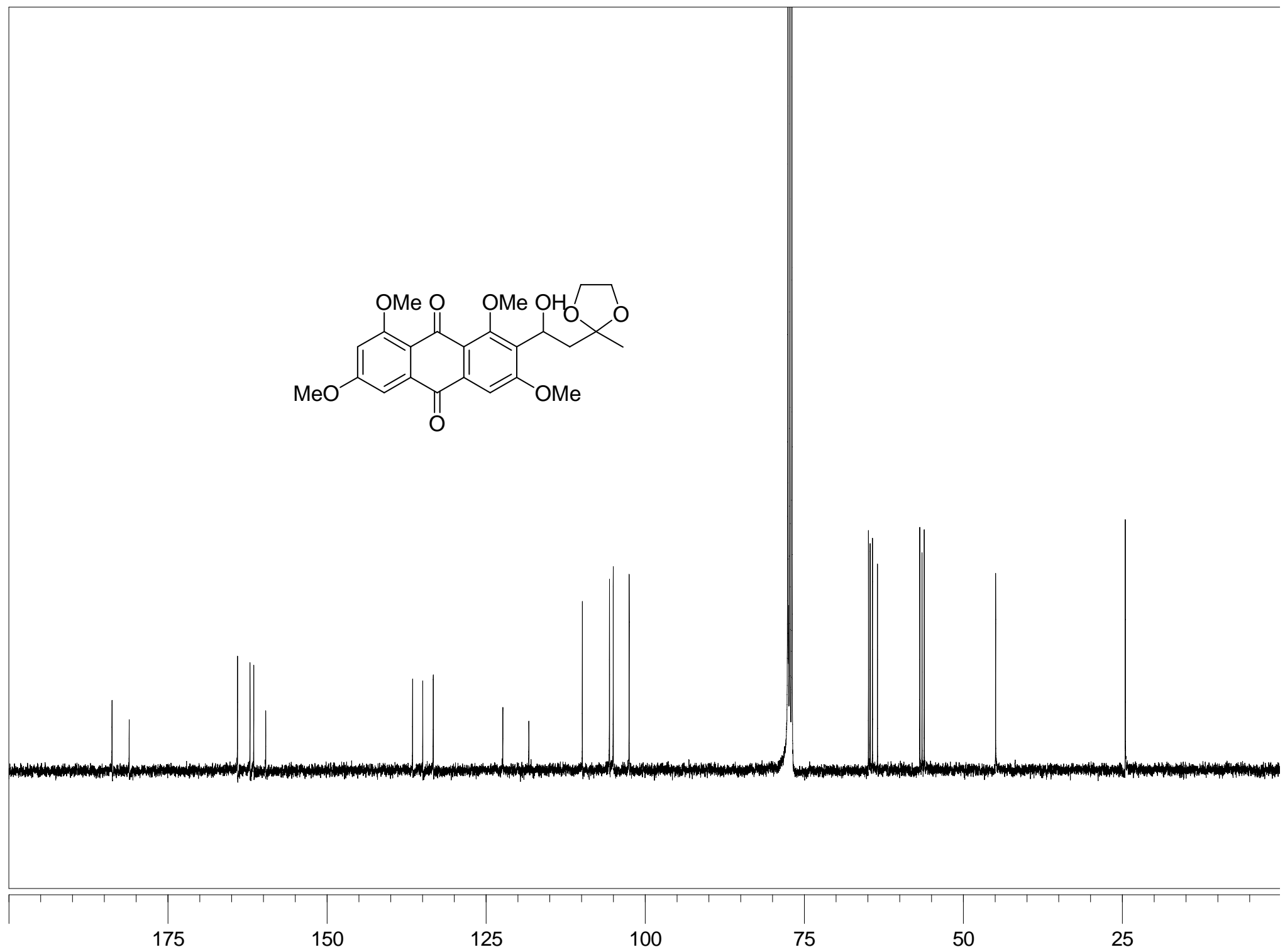




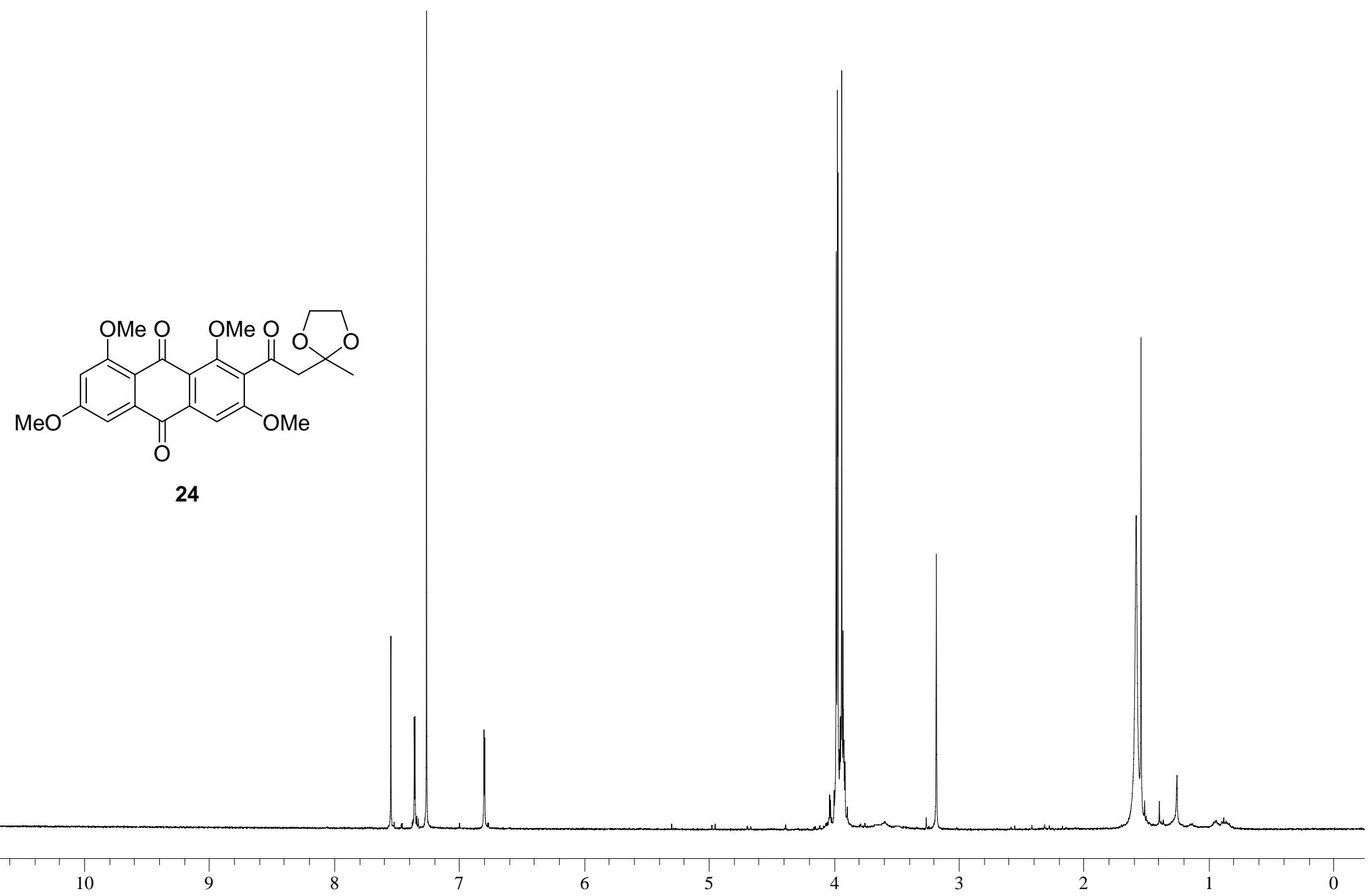




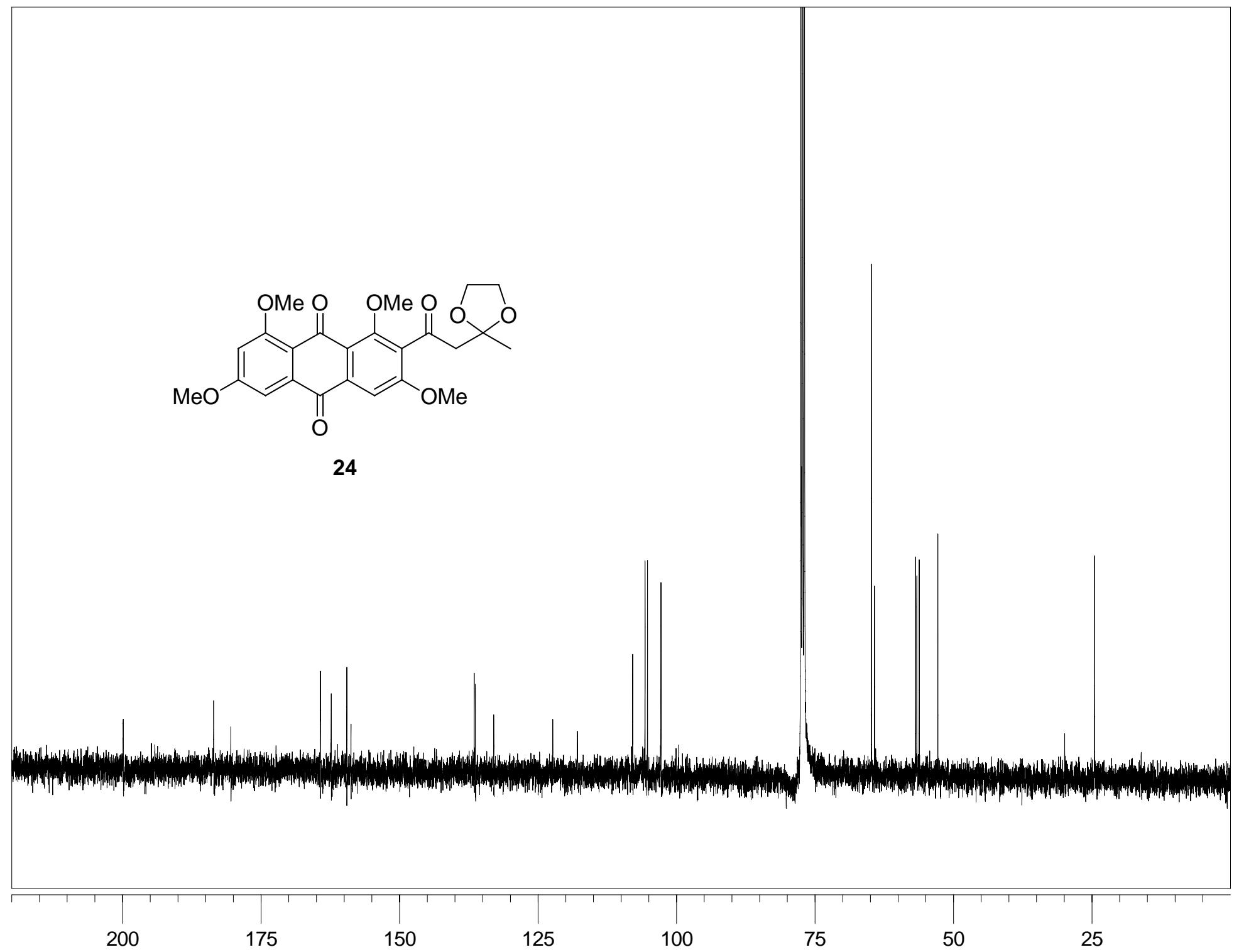



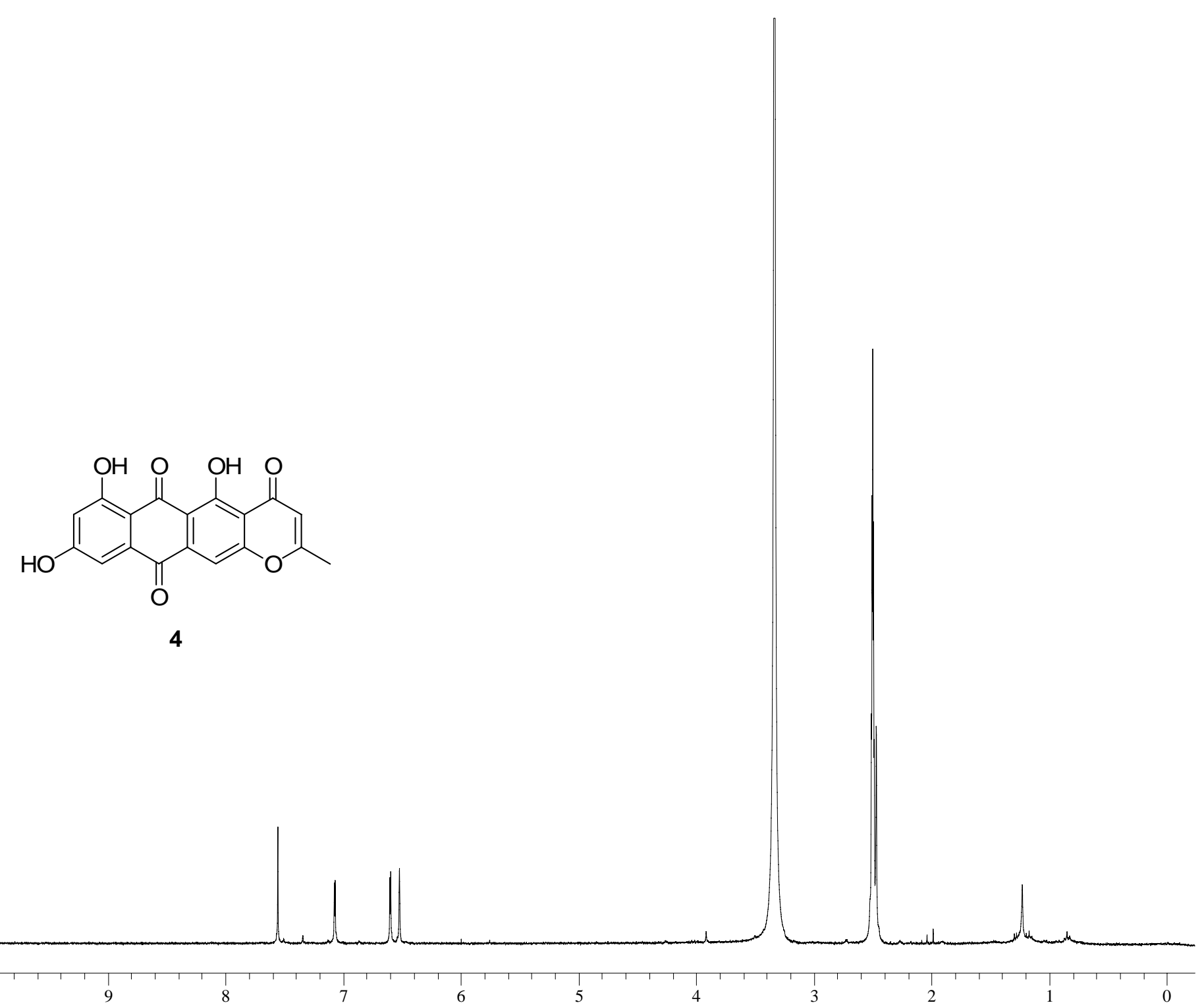
Ciufolini, M.A., et al.

\section{Synthesis of Topopyrones B and D}

S 49

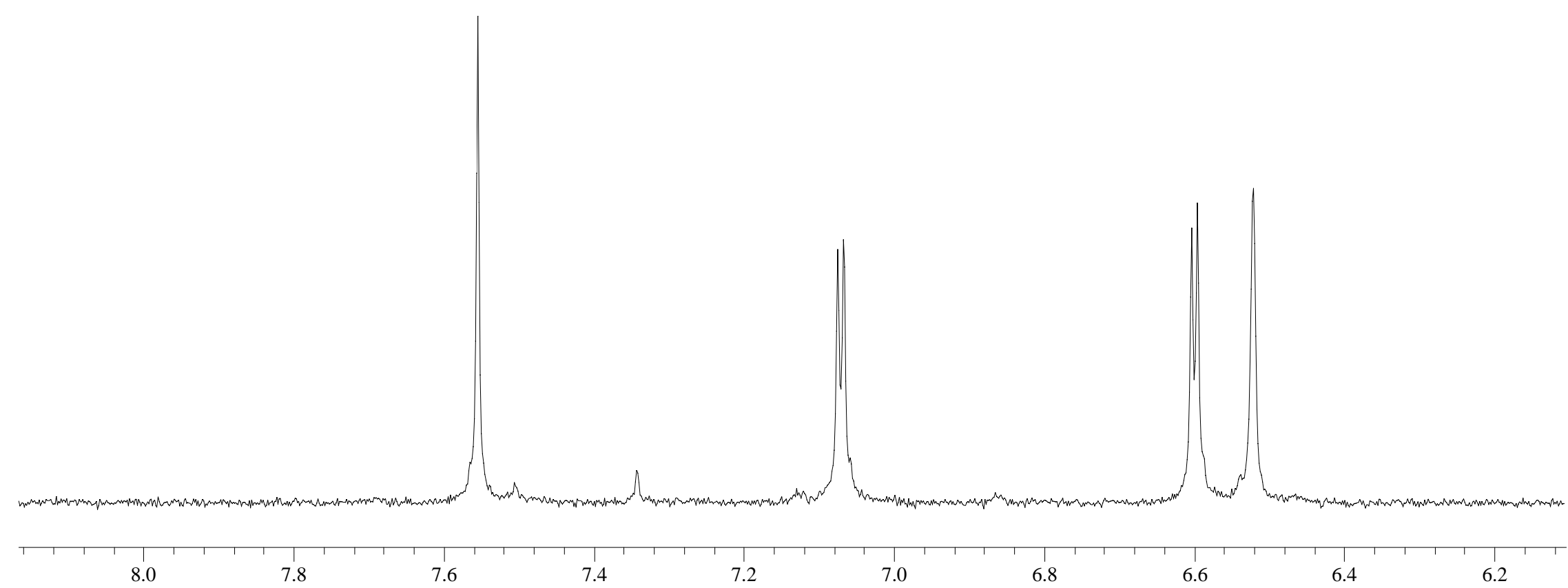


Ciufolini, M.A., et al.

Synthesis of Topopyrones B and D

S 50

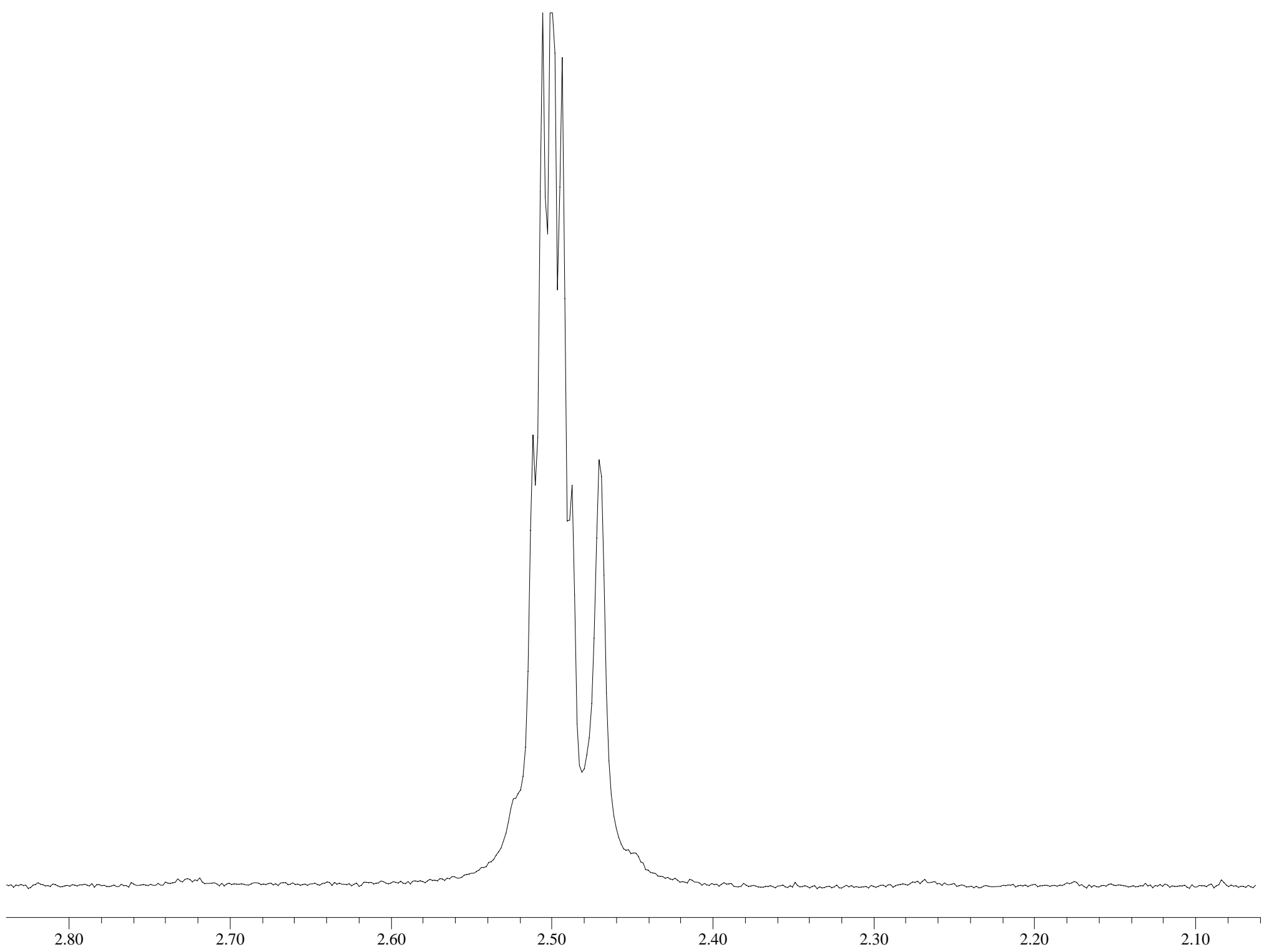




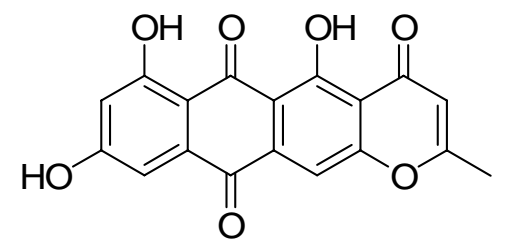

4

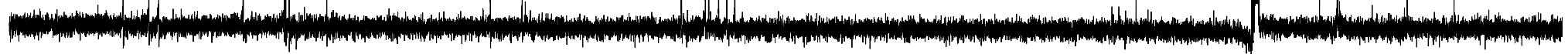




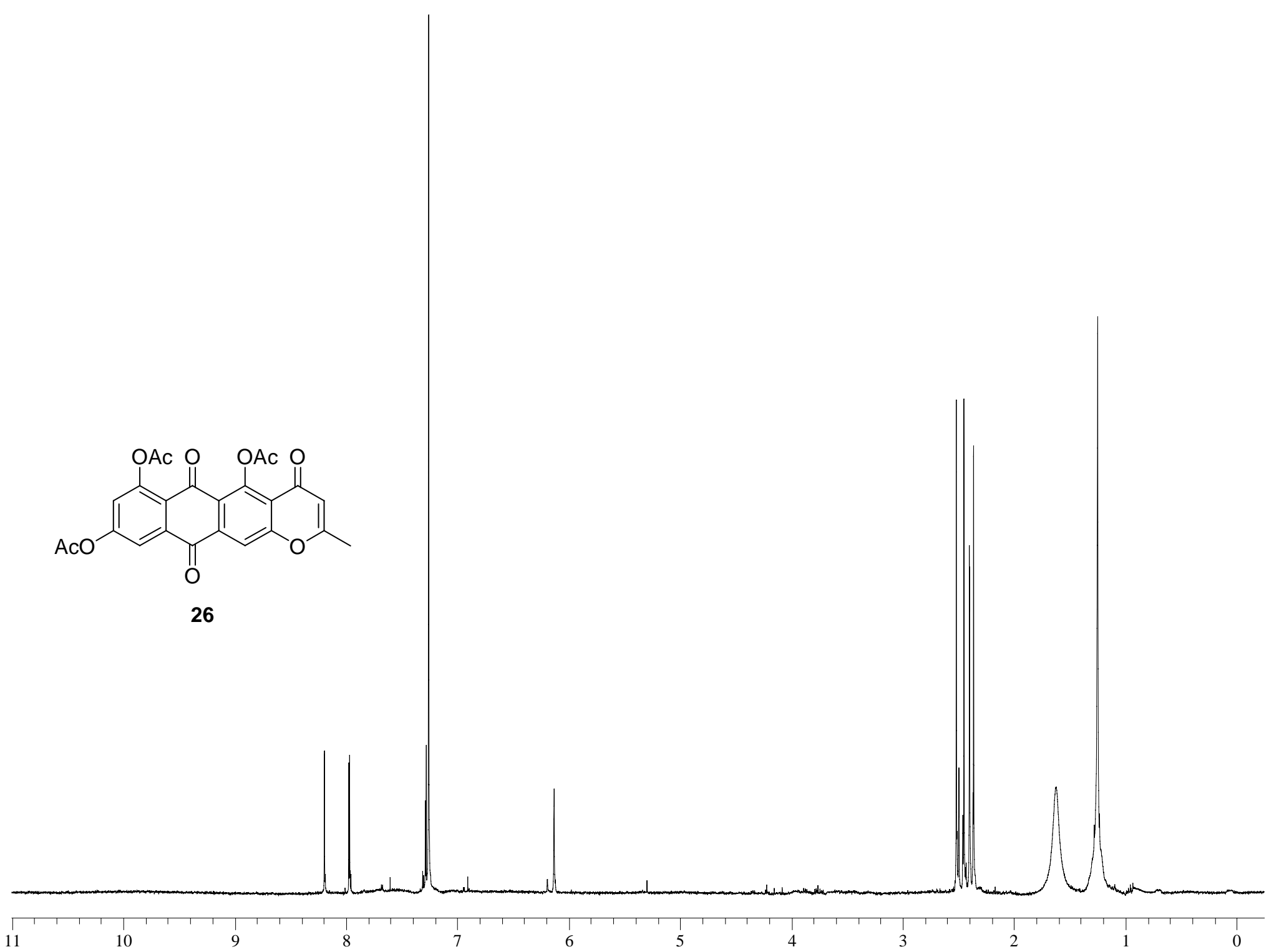




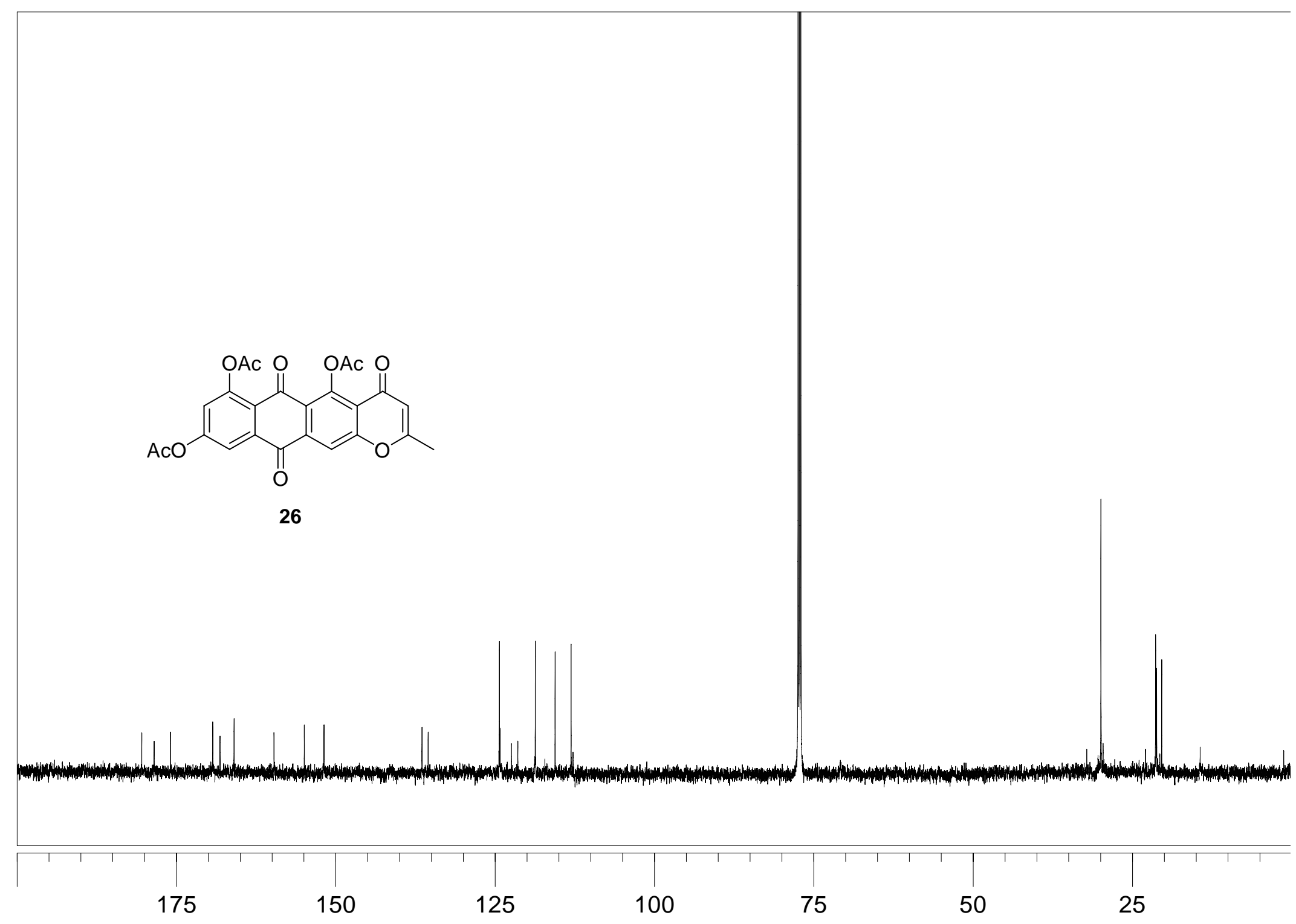




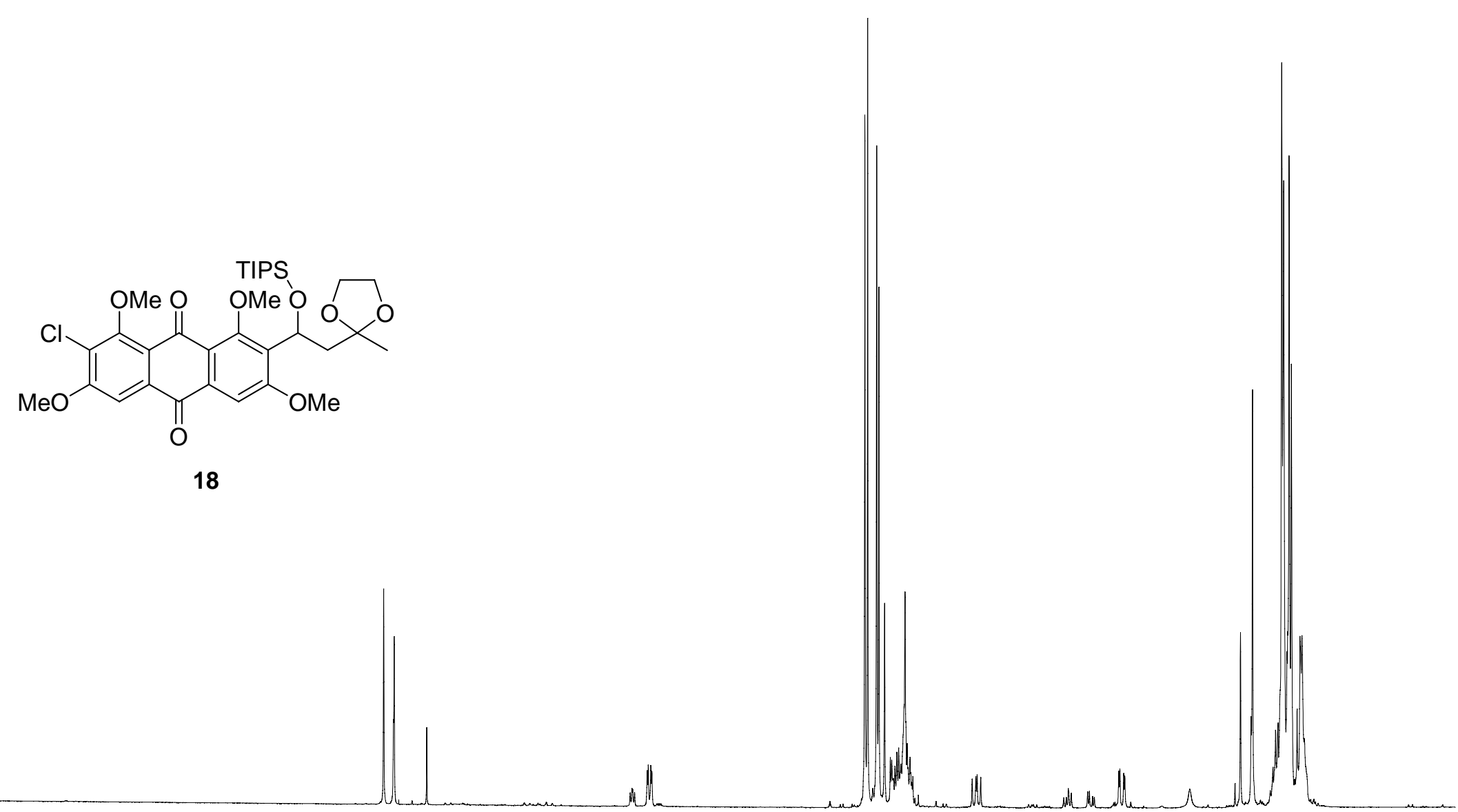




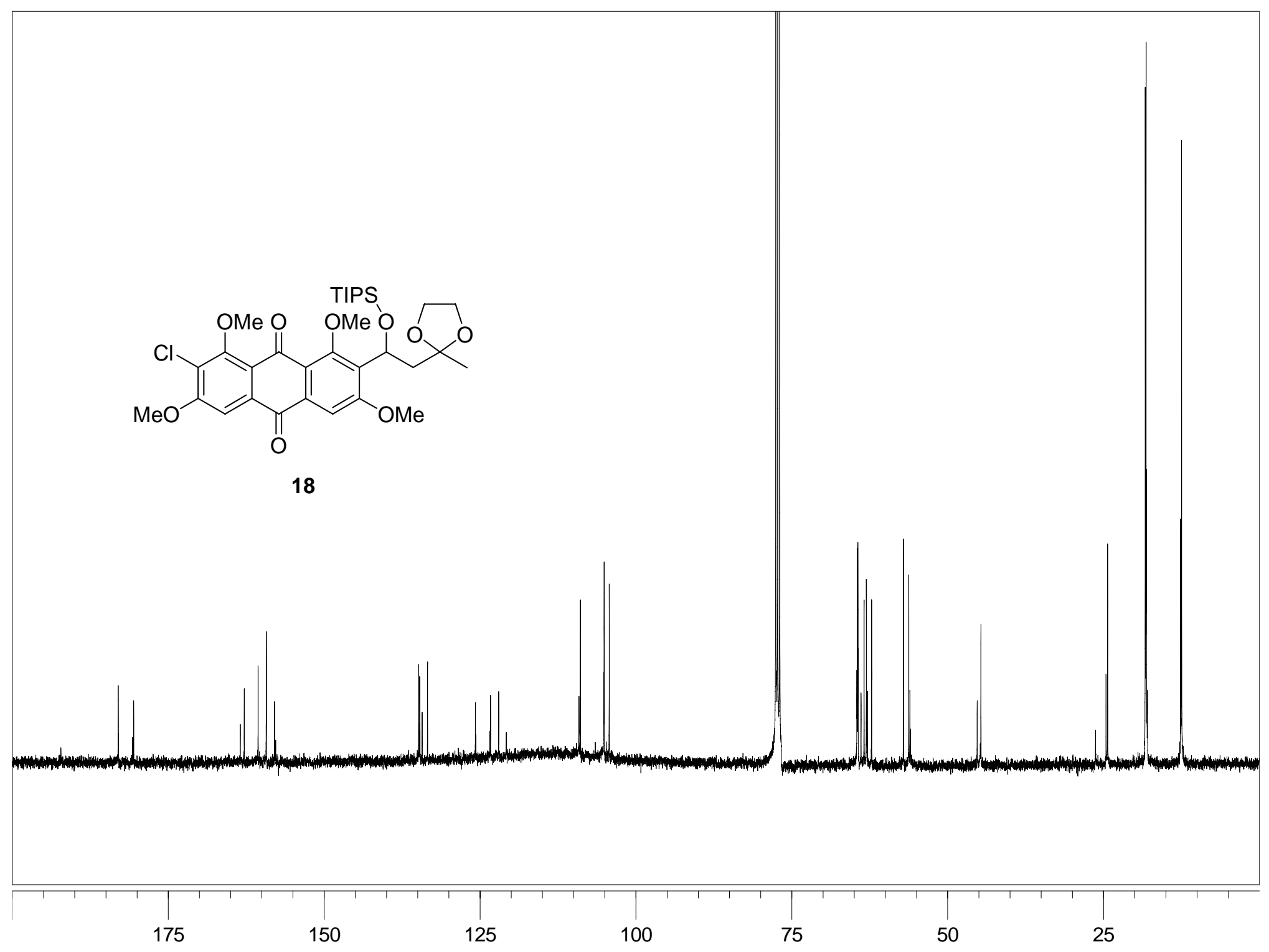




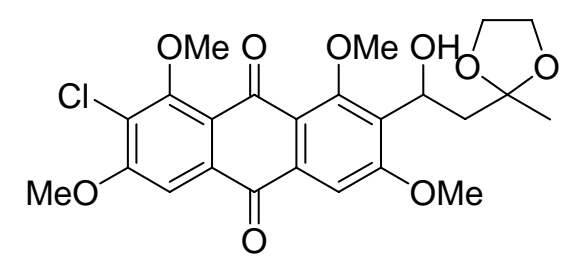




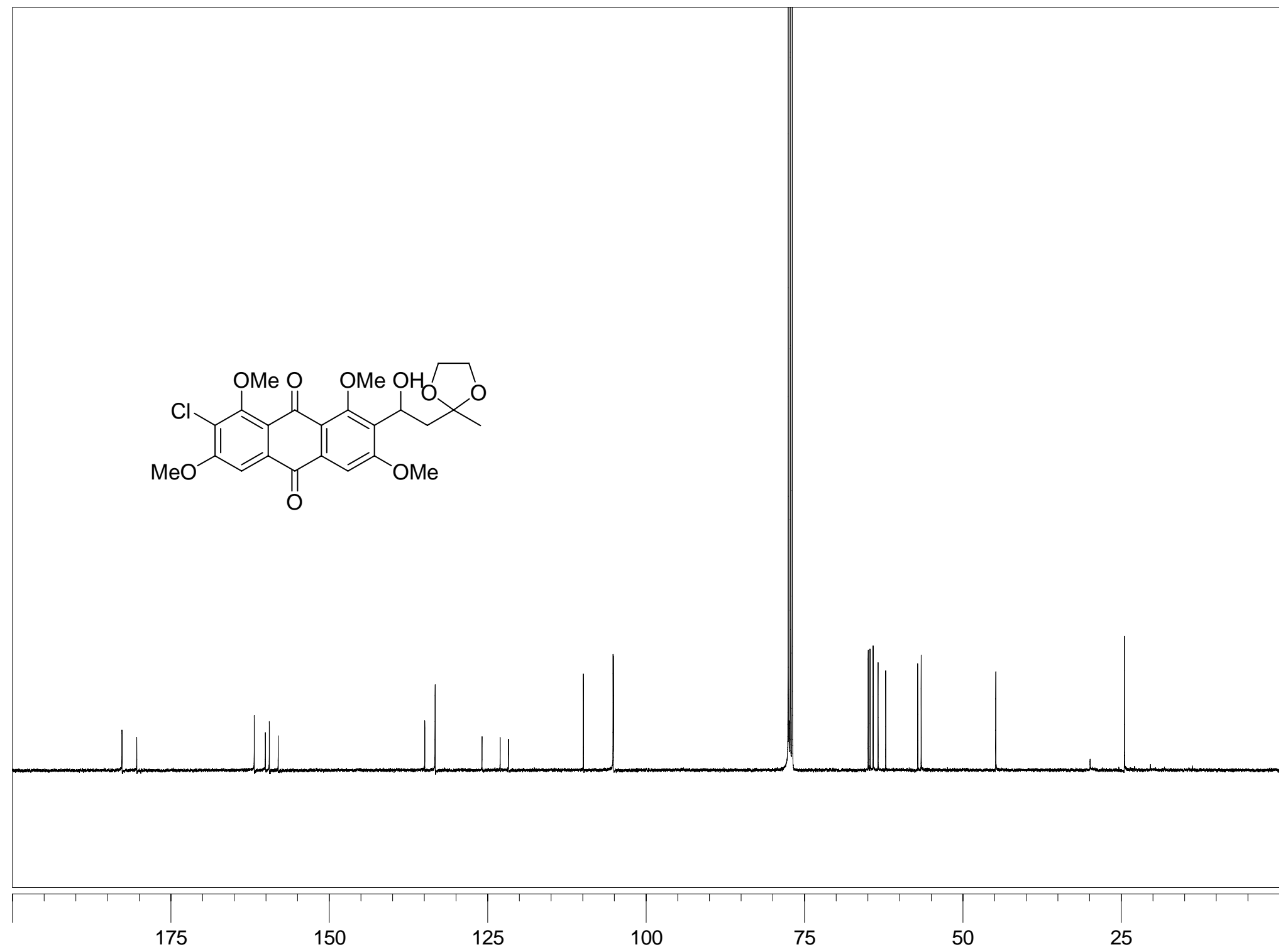


25

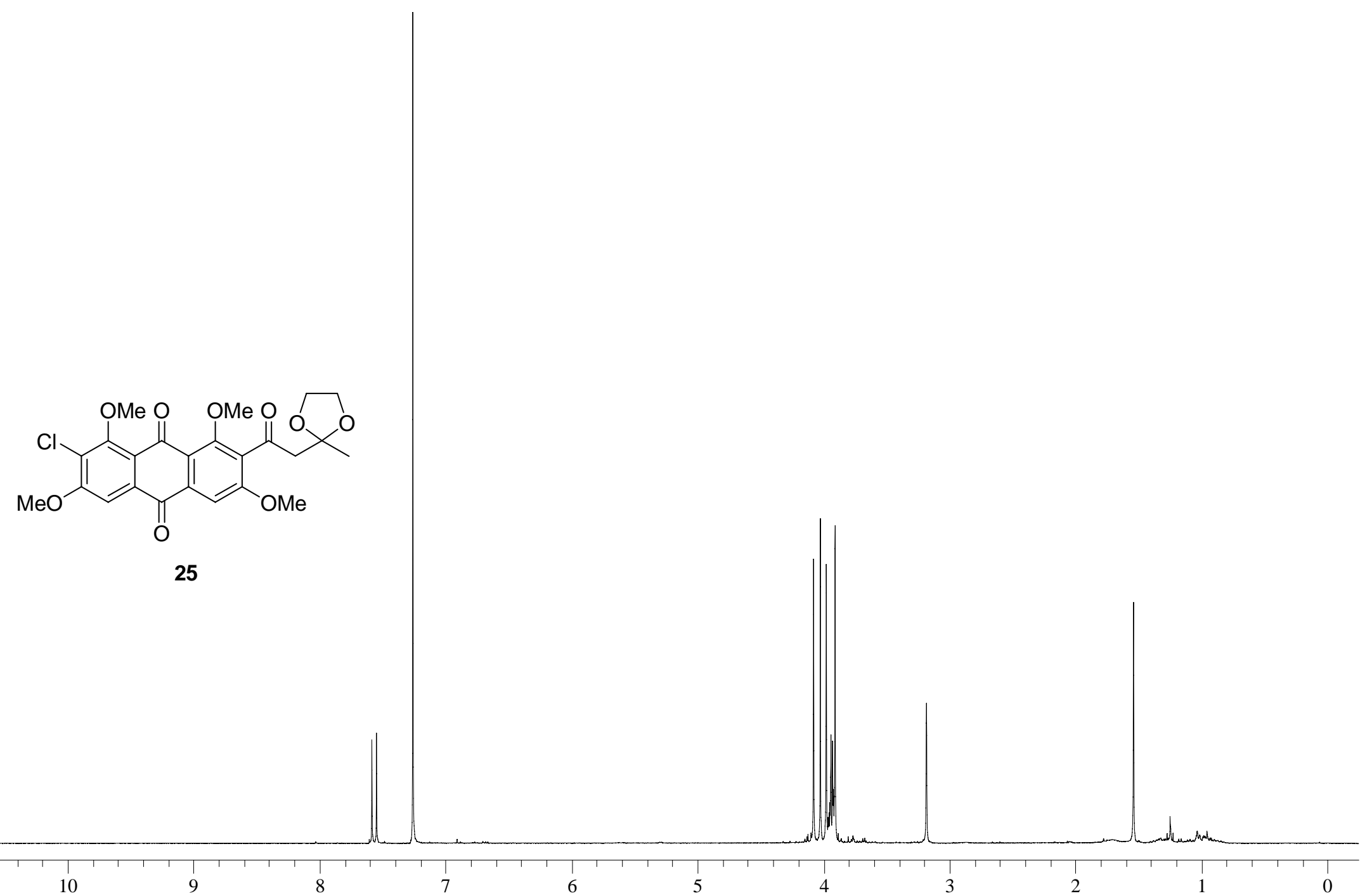




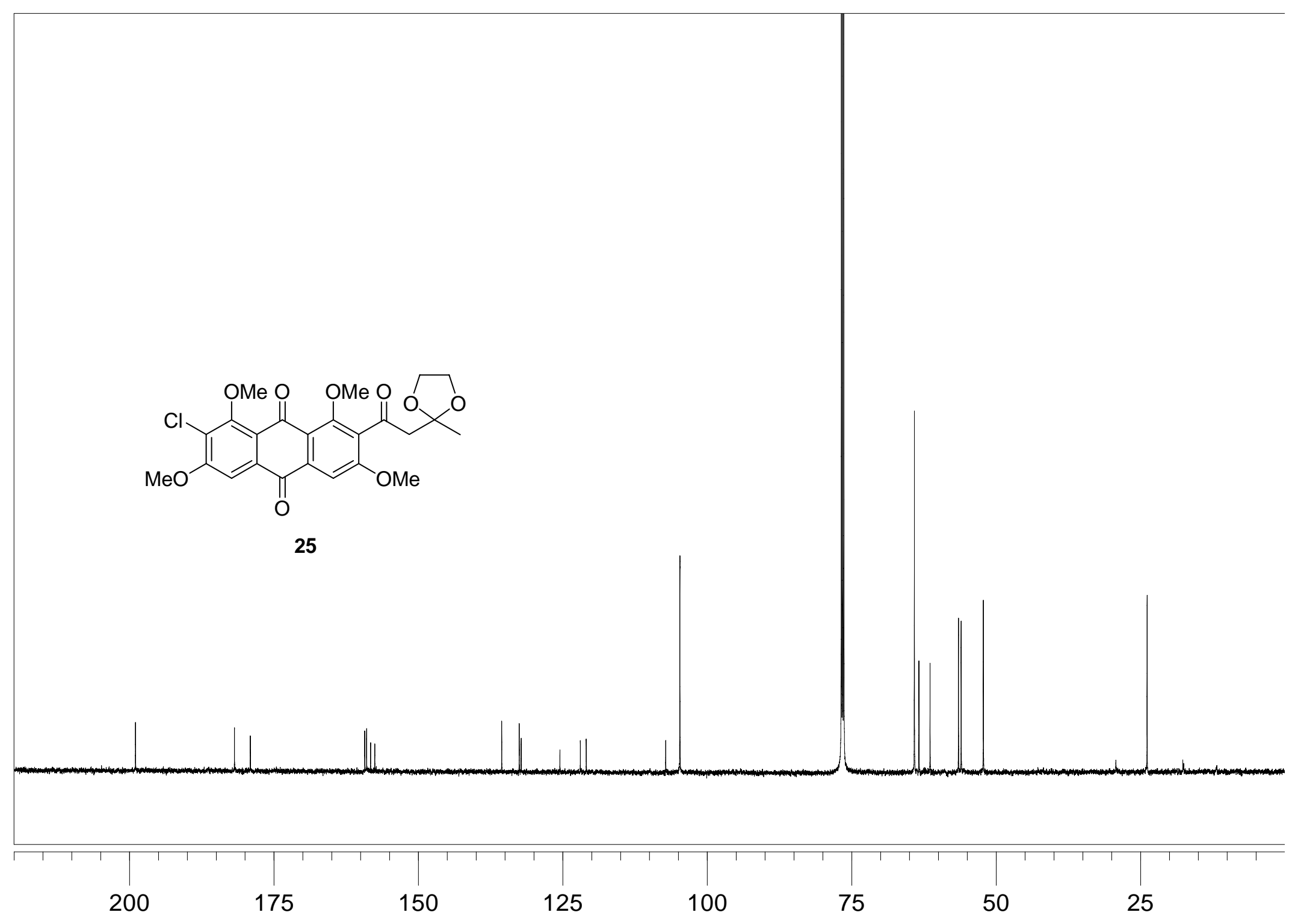




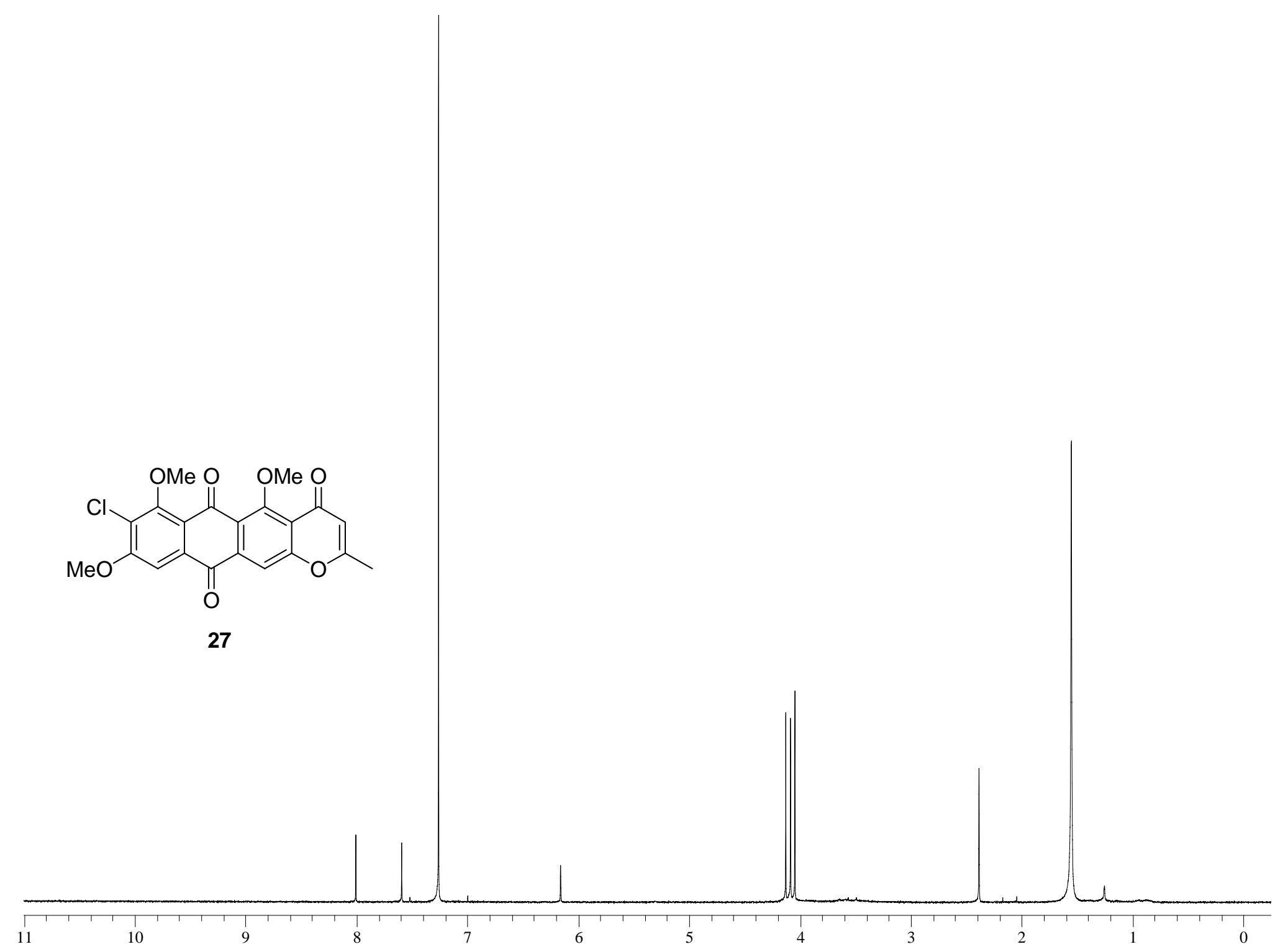




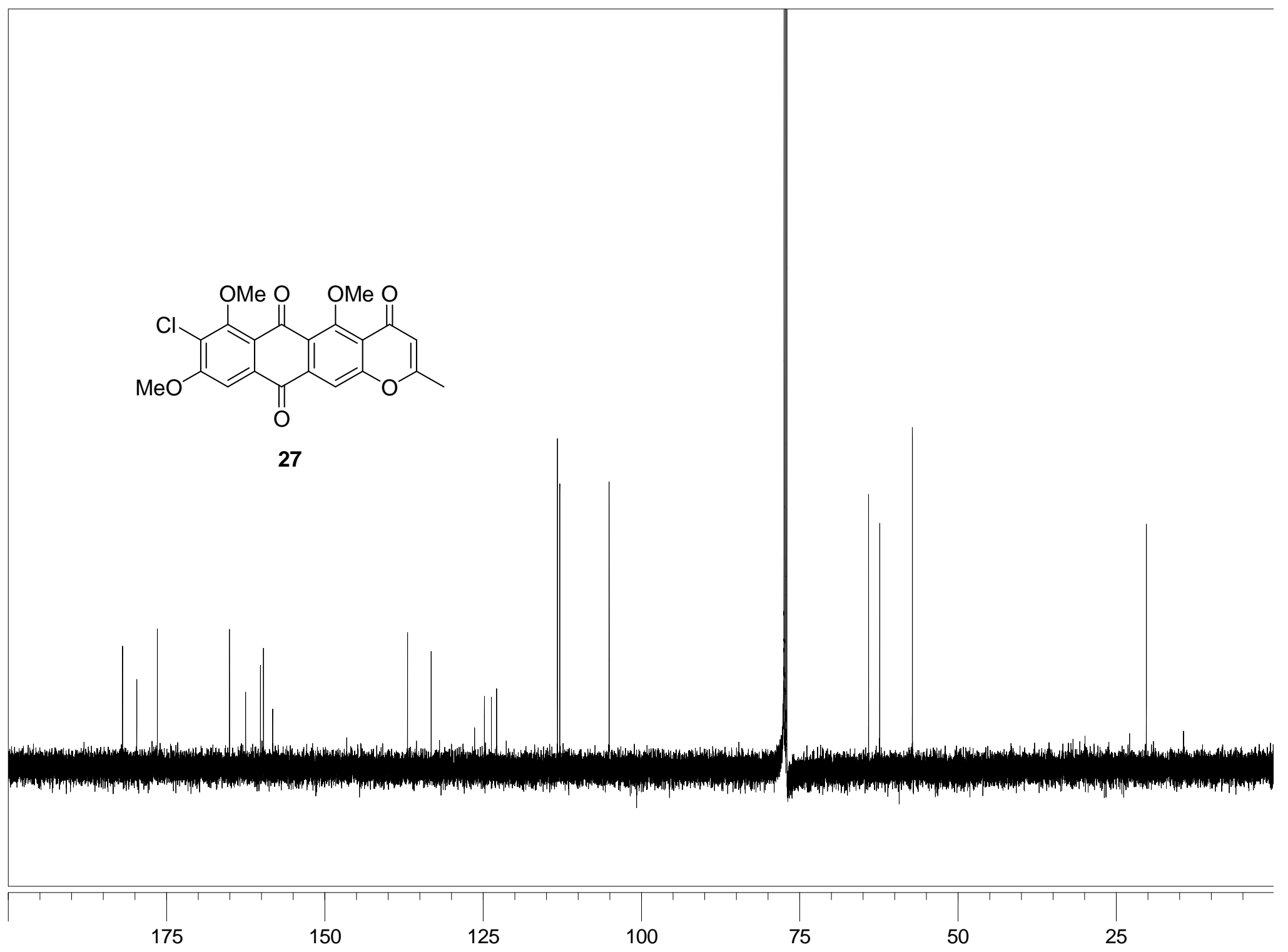

